\title{
Rule 2.1 of Ontario's Rules of Civil Procedure: Responding to Vexatious Litigation While Advancing Access to Justice?
}

\section{Gerard J. Kennedy*}

This article analyzes the first three years of the operation of Rule 2.1 of Ontario's Rules of Civil Procedure (the "Rule"), which allows a court to very summarily dismiss litigation that is "on its face" frivolous, vexatious, and/or abusive. The author explores the history of and rationale for the Rule, in the context of the access to justice crisis in Ontario, and in light of the perceived inadequacy of alternative mechanisms for addressing the dangers raised by vexatious litigants. He then reviews all 190 Rule 2.1 decisions decided between July 1, 2014 and June 30, 2017, with the goal to provide guidance for future lawyers and judges considering using the Rule. This is followed by an analysis of the effects on access to justice of the Rule, in terms of providing speedy and cost-efficient resolution of actions on their merits. The author concludes by considering how the Rule should be used in the future-doctrinally, institutionally, and ethically. His conclusions are hopeful. The Rule is powerful, and its use should prompt some pause in judges and lawyers. By and large, however, the Rule has been very well employed. It has resulted in immense savings of time and financial expense and many cases model fairness to vulnerable parties. In rare instances where the Rule's (attempted) use has been inappropriate, costs in terms of delay and financial expense are usually minimal. The Rule is ultimately an inspiring example of how civil procedure can be amended to facilitate access to justice.

Cet article analyse les trois premières années sous le régime de la règle 2.1 des Règles de procédure civile de l'Ontario (la "Règle »), qui permet à un tribunal de rejeter très sommairement une poursuite qui est, "à première vue ", frivole, vexatoire ou abusive. L'auteur étudie l'historique et la raison d'être de la Règle dans le contexte de la crise de l'accès à la justice en Ontario et de l'insuffisance perçue des autres mécanismes de lutte contre les dangers créés par les plaideurs quérulents. Il examine ensuite chacune des 190

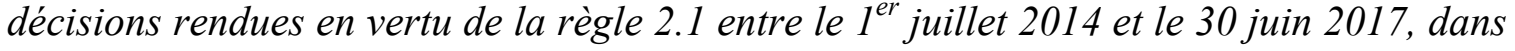
le but de formuler des conseils pour les avocats et les juges qui envisageront d'invoquer la règle dans l'avenir. Cette étude est suivie d'une analyse des effets de la Règle sur l'accès à la justice pour ce qui est de la résolution rapide et économique des litiges quant au fond. $L$ 'auteur conclut en examinant comment la Règle devrait être utilisée dans l'avenir sur le plan de la doctrine, des institutions et de l'éthique. Ses conclusions sont empreintes d'espoir. La Règle est puissante, et son utilisation devrait être un sujet de réflexion pour les juges et les avocats. Dans l'ensemble, toutefois, la Règle a été très bien utilisée. Elle a permis d'énormes économies de temps et d'argent, et bien des cas constituent des modèles d'équité pour les parties vulnérables. Dans les rares cas où les tentatives d'utilisation de la Règle étaient inappropriées, les retards occasionnés et les dépenses d'argent ont 
généralement été minimes. La Règle est finalement un exemple encourageant de la manière dont la procédure civile peut être modifiée pour faciliter l'accès à la justice.

"[The plaintiff] seeks an order requiring the government to: provide him with a job, fix issues concerning his love life, [...], allow him to carry a weapon for personal safety, [...], and to provide the plaintiff with a stealth video and audio recording device to record community thugs operating in public in violation of his rights. He also seeks damages in the amount of $\$ 151$ million."

“[The plaintiff]'s argument does not deserve respectful treatment. But she does."2

Sometimes, the just way to resolve an action is obvious. Enacted in 2014, Rule 2.1 of Ontario's Rules of Civil Procedure $e^{3}$ seeks to combine two potential solutions to Canada's access to justice crisis ${ }^{4}-$ civil procedure reform $^{5}$ and more active judging ${ }^{6}$ - in response to a discrete but real problem in Canadian civil litigation: namely, litigation that is "on its face" frivolous, vexatious, and/or abusive. Cases that fall within Rule 2.1's ambit number in the dozens per year, potentially causing disproportionate expense for responding parties, and wasting significant public resources. ${ }^{7}$

To date, no scholar has investigated Rule 2.1 (the "Rule"). ${ }^{8}$ In this article, I seek to rectify this gap. In Part I, I explore the history of and rationale for the Rule, in the context of the access to justice crisis in

* Ph.D. Candidate, Osgoode Hall Law School; Visiting Doctoral Researcher, NYU School of Law; 2016 Pierre Elliott Trudeau Foundation Scholar. This article is inspired by the second chapter of the author's doctoral dissertation, and would not have been possible but for the support of the Pierre Elliott Trudeau Foundation, the Social Sciences and Humanities Research Council, and the estate of the late Willard Z Estey. The author thanks Professor Janet Walker, B David Kennedy, the staff of the Windsor Yearbook of Access to Justice, and three anonymous peer reviewers for their comments on earlier drafts of this paper, as well as Justice Ian Nordheimer of the Court of Appeal for Ontario for discussing this topic in the paper's early stages. All views are the author's, as are any mistakes.

1 Asgharv Ontario, 2015 ONSC 4071, [2015] OJ No 3326 (SCJ) [Asghar] at para 2.

2 Lin v Rock, 2015 ONSC 2421, [2015] OJ No 1851 (SCJ) [Lin] at para 13.

3 RRO 1990, Reg 194 [the "Rules" or the "Rules of Civil Procedure" will be used interchangeably].

4 See, e.g. Trevor CW Farrow, "What is Access to Justice?" (2014) 51:3 Osgoode Hall LJ 957 [Farrow, "2014”] at fn 1 for an extensive review of the literature in this area.

5 Ontario extensively amended its civil procedure earlier this decade to facilitate the more timely and inexpensive resolution of civil actions on their merits: O Reg 438/08. This was largely to implement the recommendations of the "Osborne Report": Ontario Ministry of the Attorney General, Civil Justice Reform Project: Summary of Findings and Recommendations, by Coulter A Osborne, Nov 2007, at Appendix A (Terms of Reference) \& B (Consultation Letter). For a discussion of this, see: Brooke MacKenzie, "Effecting a Culture Shift: An Empirical Review of Ontario's Summary Judgment Reforms" (2017) 54:4 Osgoode Hall LJ 1275 at 1280-1281, fn 18; Janet Walker, "Summary Judgment Has Its Day in Court" (2012) 37 Queen's LJ 697 at 700-701 and 707-708.

6 See e.g. Hryniak v Mauldin, 2014 SCC 7, [2014] 1 SCR 87 [Hryniak] at paras 74-79.

7 Raji v Borden Ladner Gervais LLP, 2015 ONSC 801, [2015] OJ No 307 (SCJ) [Raji \#1] at para 6.

8 Some law firms have published professional resources on this topic: see, e.g., "WHAT DO I TELL A CLIENT WHO ASKS: What Do I Do When a Debtor files a 'Freeman of the Land' Claim or Motion (Sub Nom: 'Frivolous or Vexatious Claims and Motions - a Rule 2.1 Primer')," online: Papazian | Heisey | Myers <http://www.phmlaw.com/what-do-i-tellclient.pdf>; Kathryn Kirkpatrick \& Jeremy Ablaza, "Cautious Use of Rule 2.1 Against Vexatious Claims in Khan v. 
Ontario, and in light of the perceived inadequacy of alternative mechanisms provided for in the Rules and the Courts of Justice Act ${ }^{9}$ for addressing the dangers raised by vexatious litigants. In Part II, I analyze all 190 decisions using Rule 2.1 decided between July 1, 2014 and June 30, 2017 to determine how Rule 2.1 has been applied in practice, with the goal to provide guidance for future lawyers and judges considering using the Rule. In Part III, I analyze the effects on access to justice of Rule 2.1, in terms of providing speedy and cost-efficient resolution of civil actions on their merits. In Part IV, I consider how the Rule should be used in the future - doctrinally, institutionally, and ethically.

My conclusions are hopeful. Rule 2.1 is powerful, and its use should prompt some pause in judges and lawyers. By and large, however, the Rule has been very well employed. It has resulted in significant savings of time and financial expense, ${ }^{10}$ for both courts and defendants, while almost always being fair to plaintiffs. ${ }^{11}$ Despite the Rule's potential to disadvantage self-represented litigants, many cases are the model of fairness to vulnerable parties. In the few instances where the Rule's (attempted) use has arguably been inappropriate, the costs in terms of delay and financial expense are usually minimal. While Rule 2.1 is only applicable to a small minority of cases, they are not a trivial number. The Rule is ultimately an inspiring example of how civil procedure can be amended to facilitate access to justice - and be thoroughly fair to parties in doing so.

\section{RULE 2.1's HISTORY}

\section{A. Access to Justice}

Precisely what the phrase "access to justice" encompasses varies according to the circumstances. At its most holistic, it includes normative questions about what values constitute "justice" and ensuring that substantive law encompasses such values. ${ }^{12}$ At the very least, it means that civil litigation should have three characteristics: first, minimal financial costs; second, timeliness; and, third, simplicity. ${ }^{13}$ Even those who have argued that access to justice should be interpreted in a much broader manner, such as Trevor Farrow, agree that simple and efficient civil procedure is an important tool for achieving access to justice. ${ }^{14}$

Krylov \& Company LLP” (15 Aug 2017), online: Borden Ladner Gervais <http://blg.com/en/News-And-

Publications/Publication_5040>.

9 RSO 1990, c C43 [CJA].

10 Quantifying a comparison between Rule 2.1 and Rule 21 with scientific precision would be difficult if not impossible but the discussion in Part I.C should indicate the significantly greater costs of Rule 21.

11 Unless the circumstances require more specificity, the terms "defendants," "respondents," and "responding parties" will be used interchangeably in this article when referring to parties against whom Rule 2.1 is not (proposed to be) used while "plaintiffs," "applicants," and "moving parties" will be used interchangeably when referring to parties against whom Rule 2.1 is proposed to be used.

12 Farrow 2014, supra note 4 at 970-972.

13 See ibid at 978-979; Roderick A Macdonald, “Access to Justice in Canada Today: Scope, Scale and Ambitions" in Julia Bass, WA Bogart \& Frederick H Zemans, eds, Access to Justice for a New Century - The Way Forward (Toronto: LSUC, 2005) at 68-73. Related to this is the important principle of proportionality: Hryniak, supra note 6 at paras 29-33; Trevor Farrow, "Proportionality: A Cultural Revolution" (2012) 1 Journal of Civil Litigation and Practice 151 [Farrow, "2012"].

14 Trevor CW Farrow, "A New Wave of Access to Justice Reform in Canada” in Adam Dodek \& Alice Woolley, eds, In Search of the Ethical Lawyer: Stories from the Canadian Legal Profession (Vancouver: UBC Press, 2016) at 166. 
It is within this spirit of ensuring timely and cost-effective resolutions of civil claims that Ontario amended its Rules of Civil Procedure effective Jan 1, 2010. ${ }^{15}$ These reforms also enshrined the principle of proportionality, which recognizes that steps taken in litigation are to be proportionate to what can realistically be gained from taking said steps. ${ }^{16}$ In the seminal 2014 decision Hyrniak v Mauldin, Justice Karakatsanis, for a unanimous Supreme Court of Canada, held that these reforms should be interpreted generously to achieve access to justice. She also called for a "culture shift" to ensure that cases are decided on their merits in a manner that is fair, speedy, and minimally expensive. ${ }^{17}$

Hryniak concerned summary judgment. But appellate courts ${ }^{18}$ and notable commentators ${ }^{19}$ have repeatedly emphasized that Hryniak's spirit applies outside this narrow context. This spirit includes the recognition that a full, traditional trial is frequently not necessary for a court to justly resolve matters, and that more summary procedures that bring swift ends to proceedings can play indispensable roles in this respect. ${ }^{20}$ It is against this backdrop, and with these considerations in mind, that Rule 2.1 became part of the Rules effective July 1, 2014: to provide an efficient and cost-and-time-effective mechanism to address a particular type of proceeding.

\section{B. Frivolous, Vexatious, and Abusive}

Rule 2.1 combines the terms "vexatious," "frivolous," and "abusive" - terms that overlap considerably in the case law. ${ }^{21}$ The former two terms are unfortunately not well defined in case law. "Vexatious" is defined by Black's Law Dictionary as "without reasonable or probable cause or excuse; harassing; annoying" 23 and by the Ontario Court of Appeal as "broadly synonymous with the concept of abuse of process developed by the Courts in the exercise of their inherent right to control proceedings." 24 Black's Law defines "frivolous" as "lacking a legal basis or legal merit; not serious; not reasonably purposeful," 25 a definition accepted by the Ontario Court of Appeal. ${ }^{26}$

The term "abusive" relates to the doctrine of abuse of process, which the Supreme Court of Canada has noted aims to preserve the integrity of the court process. ${ }^{27}$ The Supreme Court has approvingly cited Goudge JA's description of abuse of process:

15 The Rules, supra note 3, as amended by O Reg 438/08.

16 See Farrow, "2012," supra note 13.

17 Hryniak, supra note 6 at paras 2, 23.

18 See e.g., Iannarella $v$ Corbett, 2015 ONCA 110, 124 OR (3d) 523 at para 53, concerning discovery; Canadian Natural Resources Limited v ShawCor Ltd, 2014 ABCA 289, 580 AR 265 at para 5, concerning the intersection between discovery and claims of privilege.

19 See, e.g., Stephen GA Pitel \& Matthew Lerner, "Resolving Questions of Law: A Modern Approach to Rule 21" (2014) 43 Adv Q 344 at 344-346.

20 Hryniak, supra note 6 at para 29; Pitel \& Lerner, ibid.

21 Butera $v$ Fragale, 2010 ONSC 3702, 2010 CarswellOnt 4669 (SCJ) at para 19.

22876502 Ontario Ltd v IF Propco Holdings (Ontario) 10 Ltd (1997), 37 OR (3d) 70 (Gen Div) at 77.

23 Black's Law Dictionary, 7th ed [Black's Law], sub verbo "vexatious."

24 The dissenting opinion of Blair JA in Foy $v$ Foy (1979), 26 OR (2d) 220 (CA), accepted in subsequent case law: see Dale Streiman \& Kurz LLP v De Teresi (2007), 84 OR (3d) 383 (SCJ) at para 7.

25 Black's Law, supra note 23, sub verbo "frivolous."

26 Currie v Halton Regional Services Police Board (2003), 179 OAC 67 (CA) at para 17.

27 Behn v Moulton Contracting Ltd, 2013 SCC 26, [2013] 2 SCR 227 [Behn] at para 40. 
[The doctrine of abuse of process] engages the inherent power of the court to prevent the misuses of its procedure, in a way that would be manifestly unfair to a party to the litigation before it or would in some other way bring the administration of justice into disrepute. It is a flexible doctrine unencumbered by the specific requirements of concepts such as issue estoppel. $[\ldots]^{28}$

These three terms overlap. ${ }^{29}$ "Abusive" is the broadest, and frivolous and vexatious litigation is almost certainly also going to be abusive. However, "vexatious" is the commonly used term if referring to persons in case law. "Abusive" tends to refer to litigation itself. As such, I will use "abusive" and "vexatious" synonymously hereafter, unless circumstances call for more specificity. I will generally avoid "frivolous," which truly seems to be a subset of vexatious and abusive.

\section{Vexatious Litigants Prior to Rule 2.1}

Rule 21.01(b) of Ontario's Rules of Civil Procedure allows a party to bring a motion to dismiss a proceeding on the grounds that "it discloses no reasonable cause of action." ${ }^{" 30}$ This is a modern codification of common law courts' historic power to prevent abuses of process; an action that does not disclose a cause of action is an example of an abuse of process. ${ }^{31}$ As such, this Rule can be used to strike abusive pleadings. Rule 25.11 of the Rules, which allows a court to strike "all or part of a pleading or other document" if it is "scandalous, vexatious, or frivolous" ${ }^{32}$ or "is an abuse of process of the court" another tool in this respect. However, these rules have their limits. First, they require a formal motion, requiring legal argument and notice to the allegedly abusive party. In addition to being expensive and time-consuming, in the words of Myers J, this can lead to "the proposed cure caus[ing] a fresh outbreak of the disease," giving the allegedly vexatious litigant a new opportunity to act vexatiously. ${ }^{34}$ Second, if the vexatious party is engaged in a pattern of behaviour, motions will need to be brought repeatedly.

Alternatively, s 140 of the CJA prescribes a procedure to have a litigant declared "vexatious" 35 if he or she has "instituted vexatious proceedings in any court" or "conducted a proceeding in a vexatious manner." ${ }^{36}$ The consequences of this are that no further proceedings may be instituted or continued by the vexatious litigant without leave of a Superior Court judge. ${ }^{37}$ Once granted, a "vexatious litigant order" allows a responding party to ensure any further proceeding or step therein brought by the vexatious litigant

28 Ibid [emphasis added by LeBel J], citing Canam Enterprises Inc v Coles (2000), 51 OR (3d) 481 (CA) [Canam] at para 55.

29

Maheau v IMS Health Canada, 2002 FCT 558, 20
226 FTR 269, aff'd, 2003 FCA 462, 314 NR 393.

30 Rules, supra note 3.

31 Pitel \& Lerner, supra note 19 at 348.

32 Rules, supra note 3, Rule 25.11(b).

3 Ibid, Rule 25.11(c).

Raji \#1, supra note 7 at para 8.

5 CJA, supra note 9, s 140(1)(a).

36 Ibid, s 140(1)(b).

37 Ibid, ss $140(1)(\mathrm{c}-\mathrm{d})$. 
has at least some prima facie merit. It also helps the vexatious litigant by ensuring judicial oversight over all litigation steps, saving all parties - including the vexatious litigant - unnecessary expense. ${ }^{38}$

Though the remedies resulting from s 140 of the CJA are more powerful than those available from Rule 21 or 25.11 , they present other difficulties. First, s 140 requires a separate application to be commenced ${ }^{39}$ - an expensive and lengthy process. ${ }^{40}$ Although Rule 38.13 of the Rules, which became effective July 1 , 2014, mandates that applications under this section are generally to be heard in writing, and factums are not required, an application record is still necessary. ${ }^{41}$ Vexatious litigants still have many opportunities to respond vexatiously, through submitting an affidavit, and cross-examining other parties on their affidavit(s). Second, a vexatious litigant declaration is difficult to obtain. It can only be granted if a person has "persistently and without lawful grounds" 42 acted in a vexatious manner. Given that it affects how a person can exercise his or her right to access the courts, it is quite rightly an extraordinary remedy. ${ }^{43}$

The limitations of s 140 of the CJA and Rules 21 and 25.11 of the Rules are well-founded. But they still leave parties responding to abusive actions in the unenviable position of bringing expensive motions and/or applications to address vexatious litigants. As Myers J wrote in Raji: $:^{44}$

The court has always had difficulty with the Catch-22 nature of dealing with vexatious litigants. Any time that proceedings are brought to try to end a vexatious proceeding, the vexatious litigant is provided with a fresh opportunity to conduct that proceeding in a vexatious, expensive, wasteful, and abusive manner. [...] Imposing a quick and limited written process that provides one opportunity to the plaintiff to show why the claim should not be dismissed is an important advance toward meeting the goals of efficiency, affordability, and proportionality in the civil justice system as discussed by the Supreme Court of Canada in Hryniak.

It was to address this situation, where it is easy to understand why a defendant would consider paying an unprincipled settlement to have the plaintiff "go away," that Rule 2.1 was enacted.

\section{HOW IT WORKS}

As noted above, one purpose of this analysis is to provide the first doctrinal analysis of Rule 2.1, assisting future lawyers, judges, and scholars seeking to use and/or analyze this Rule. ${ }^{45}$ As such, it was

38 Science Applications International Corp v Pagourov, 2012 ONSC 6514, [2012] OJ No 5696 (SCJ) [Pagourov] at para 49, citing Law Society of Upper Canada v Chavali, [1998] OJ No 5890 (Gen Div) at para 26.

39 S 140(1).

$40 \quad$ Raji $\# 1$, supra note 7 at para 8.

41 Rules, supra note 3, Rule 38.13.

42 CJA, supra note 9, s 140(1) [emphasis added].

43 Kallaba v Bylykbashi (2006), 207 OAC 60 (CA) at para 31.

44 Raji \#1, supra note 7 at para 8.

45 The utility of this endeavour was noted by Justice David Stratas in "The Decline of Legal Doctrine" (Keynote Address Delivered at the Canadian Constitution Foundation Law \& Freedom Conference, Hart House, University of Toronto, 8 Jan 2016), online: <https://www.youtube.com/watch?v=UxTqMw5v6rg>; David Stratas, "The Canadian Law of Judicial 
necessary to analyze the cases as scientifically as possible to determine "leading" cases. ${ }^{46}$ It must be recognized that "objectively" determining how a legal rule works in practice through case law is, to a certain extent, an impossible exercise. ${ }^{47}$ But textbooks and articles can still be very useful to practitioners and future scholars. ${ }^{48}$ In this respect, I hope that this section of this article not only "sets the stage" for the subsequent analysis of the Rule's utility as an access to justice mechanism, but is also useful in and of itself.

\section{A. The Mechanics}

Rule 2.1.01 provides (omitting references to forms and regulations):

1) The court may, on its own initiative, stay or dismiss a proceeding if the proceeding appears on its face to be frivolous or vexatious or otherwise an abuse of the process of the court.

\section{Summary Procedure}

2) The court may make a determination under subrule (1) in a summary manner, subject to the procedures set out in this rule.

3) Unless the court orders otherwise, an order under subrule (1) shall be made on the basis of written submissions, if any, in accordance with the following procedures:

1. The court shall direct the registrar to give notice [...] to the plaintiff or applicant, as the case may be, that the court is considering making the order.

2. The plaintiff or applicant may, within 15 days after receiving the notice, file with the court a written submission, no more than 10 pages in length, responding to the notice.

3. If the plaintiff or applicant does not file a written submission that complies with paragraph 2 , the court may make the order without any further notice to the plaintiff or applicant or to any other party.

$[\ldots]$

\section{Request for Order}

Review: Some Doctrine and Cases," March 26, 2018, online:

http://papers.ssrn.com/sol3/papers.cfm?abstract_id=2924049.

46 See, e.g., Terry Hutchinson \& Nigel Duncan, "Defining and Describing What We Do: Doctrinal Legal Research" (2012)

17:1 Deakin L Rev 83 at 110. My methodology appears in more detail in Appendix A.

47 Ibid at 84, quoting Oliver Wendell Holmes Jnr, "The Path of Law" (1897) 10:8 Harv L Rev 457 at 465-466. I am bringing my biases, as are the judges who have used and will use the Rule - much of the Critical Legal Studies movement, and related feminist and critical race critiques of law, are based on observations such as these: see e.g. Patricia J Williams, "The Pain of Word Bondage" in The Alchemy of Pain and Rights (Cambridge, MA: Harvard University Press, 1991) ch 8.

48 Stratas, supra note 45. 
4) Any party to the proceeding may file with the registrar a written request for an order under subrule (1).

\section{Notification of Court by Registrar}

5) If the registrar becomes aware that a proceeding could be the subject of an order under subrule (1), the registrar shall notify the court.

Rule 2.1.02 prescribes a similar procedure for a frivolous, vexatious, and/or abusive motion.

The Rule's language contemplates that "unless the court orders otherwise," determinations under it are to be made on the basis of written submissions, after notice. In 13 cases, a judge has dispensed with the notice requirement and dismissed the motion or proceeding without notice. I return to these rare instances below in Parts II.B.5 and IV.A.3. In almost all other cases, the judge will either issue notice that he or she is considering using Rule 2.1 or decline to do so. The cases where notice was neither issued nor a decision made declining to do so are three cases where Rule 2.1 was raised by a party in the context of a broader motion. $^{49}$

Generally speaking, upon learning of a potentially abusive proceeding, a judge shall decide whether to order notice to the party that the Court is considering dismissing his or her action. The party is then permitted to respond as to why the action should not be dismissed. After receiving those submissions (or not receiving them ${ }^{50}$ ), the judge will decide whether to dismiss the action.

Appeals of dismissals of actions under Rule 2.1 proceed to the Divisional Court or Court of Appeal as per normal appellate practice. ${ }^{51}$ Decisions not to use Rule 2.1 are presumably interlocutory matters where leave to appeal to the Divisional Court would be required. ${ }^{52}$ However, I found no decision to not use Rule 2.1 that was appealed. The Court of Appeal has prescribed particular procedural steps to be followed if a party wishes to employ the Rule in that court. ${ }^{53}$

\section{B. No Evidence or Legal Argument}

No evidence is permitted in Rule 2.1 considerations ${ }^{54}$ while formal motions under Rule 20 allow for very brief, if appropriate - dispositive evidence. ${ }^{55}$ Legal submissions are generally forbidden as well.

49 Nguyen v Economical Mutual Insurance Co, 2015 ONSC 2646, 49 CCLI (5th) 144 (SCJ) [Nguyen v Economical]; Fine v Botelho, 2015 ONSC 6284, [2015] OJ No 5321 (SCJ) [Fine]; Caliciuri v Matthias, 2017 ONSC 748, [2017] OJ No 547 (SCJ) [Caliciuri].

50 This happens not infrequently: see e.g. Strang v Ontario, 2017 ONSC 1625, [2017] OJ No 1297 (SCJ); Reyes v KL, 2017 ONSC 2304, [2017] OJ No 2195 (SCJ) [Reyes $v$ KL].

51 CJA, supra note 9, ss 19(1)(a) and 19(1)(c); John Sopinka \& Mark A Gelowitz, The Conduct of an Appeal, 3d ed (Toronto: LexisNexis, 2012) at \$5.1-5.2.

52 CJA, ibid, s 19(1)(b); Sopinka \& Gelowitz, ibid at $\$ 5.46$.

53 Simpson v The Chartered Professional Accountants of Ontario, 2016 ONCA 806, 5 CPC (8th) 280 [Simpson] at paras 45-46.

$54 \quad$ Ibid at paras $10-12$.

55 Of course, submissions and evidence under Rule 20 are frequently not brief (in Hryniak itself, they were extensive) but there is nothing inherent about the Rules mandating needless detail, with the principle of proportionality suggesting that brevity can be - and in certain cases, should be - appropriate. 
Though the Rule's language contemplates responding submissions in certain circumstances, in practice, judges almost never ask for them.

One exception and one caveat have nonetheless emerged to this general prohibition on legal submissions or evidence when applying Rule 2.1. The exception is when the responding party's reason for submitting that the action is abusive and/or vexatious is because the issues have been finally determined in another proceeding. ${ }^{56}$ I return to the soundness of this "attempt to re-litigate" exception in Part IV.A.2, below.

The caveat is when the judge deems it appropriate to ask the responding party for submissions due to concern that there may be a serious issue that warrants attention, albeit in another forum. For example, in one case, the plaintiff alleged that his child had been kidnapped. Myers J noted that the pleading left no doubt about the abusiveness of the proceeding, including racist attacks upon an obstetrician, as well as the inappropriateness of the civil courts to address any legitimate concern. He still sought submissions from the defendant's counsel, as an officer of the court, in case "something horrible was indeed happening" ${ }^{57}$ that would require a prompt response, such as from the police or child protection authorities. The defendant's counsel submitted that the child had been taken into protective custody, allowing Myers J to give directions to the plaintiff on how to challenge such a decision. This is appropriate to ensure an injustice does not occur, but should: a) be done only when the plaintiff's claim in any event appears appropriate to dismiss; and b) have no bearing on the decision to use Rule 2.1, but rather simply give guidance to the plaintiff.

\section{The Test to Use the Rule}

In deciding whether to order notice, two factors have emerged as relevant. First, when read extremely generously, no cause of action should be discernible. Second, there should be something emerging from the pleadings that suggests the extremely attenuated process is appropriate - largely because of a fear that the litigant will act vexatiously. Myers J originally proposed these two criteria, ${ }^{58}$ and the Court of Appeal endorsed them in Scaduto v Law Society of Upper Canada. ${ }^{59}$

\section{1. "On Its Face" Being Frivolous, Vexatious, and/or Abusive}

How can one say that a pleading "on its face" appears abusive? Perhaps the most common phrase is that it is for "the clearest of cases" that cannot possibly succeed, ${ }^{60}$ also described as "usually obvious" and "not for close calls." ${ }^{\text {"62 }}$ Summarizing this area of law, Trimble J held that a claim must be "so clearly frivolous as to make a motion under another Rule, on evidence and proper formal notice, a waste of time, money, and resources for the parties and the public." ${ }^{\prime 63}$

\footnotetext{
See e.g. Simpson, supra note 53.

Kadiri v Harikumar, 2015 ONSC 4894, [2015] OJ No 4103 (SCJ) [Kadiri] at para 7.

Raji \#1, supra note 7 at para 9.

2015 ONCA 733, 343 OAC 87 at para 12, leave to appeal ref'd, [2015] SCCA No 488 [Scaduto].

Scaduto, ibid at para 8.

Asghar v Alon, 2015 ONSC 7823, [2015] OJ No 6573 (SCJ) [Asghar v Alon] at para 4.

Gao v Ontario (Workplace Safety \& Insurance Board), 2014 ONSC 6100, 37 CLR (4th) 1 (SCJ) at para 9.

Beatty v Office of the Children's Lawyer, 2016 ONSC 3816, [2016] OJ No 3024 (SCJ) [Beatty] at para 13.
} 
Upon reading the pleadings and any submissions, a judge must look for any cause of action, even one buried in an otherwise abusive pleading. Myers J wrote the following in Gao \#2:

It should be borne in mind however, that even a vexatious litigant can have a legitimate complaint. [...] Care should be taken to allow generously for drafting deficiencies and recognizing that there may be a core complaint which is quite properly recognized as legitimate. $^{64}$

The Court of Appeal has asked parties to consider whether summary judgment or pleadings motions are more appropriate than requests to use Rule 2.1. ${ }^{65}$ Even so, Rule 2.1 has been enacted for a reason and should be applied "robustly" when appropriate ${ }^{66}$ or "to its fullest extent, if applicable." 67 While generous and broad readings of pleadings are called for, this does not warrant "tortured" readings. ${ }^{68}$

\section{Hallmarks of Abusiveness}

Rules 20,21, and 25.11 all allow for summary determination of claims that can clearly be shown to have no merit. As such, something more is generally required to employ Rule 2.1. This accords with the Rule being designed to address instances where a "proposed cure" (i.e, a dispositive motion) would "cause[] a fresh outbreak of the disease."69 Essentially, there should be something in the impugned pleading or other document that suggests a party will conduct the litigation vexatiously. Myers $\mathrm{J}$ has suggested that the following are helpful indicia that a claim may be (but is not necessarily) likely to be abusively litigated:

- Curious formatting

- Many, many pages

- Odd or irrelevant attachments - e.g., copies of letters from others and legal decisions, UN Charter on Human Rights, all usually, extensively annotated.

- Multiple methods of emphasis including: highlighting (various colours), underlining, capitalization.

- Repeated use of “، ', ???, !!!

- Numerous foot and marginal notes. [...]

- Rambling discourse characterized by repetition and a pedantic failure to clarify.

- Rhetorical questions.

- Repeated misuse of legal, medical and other technical terms.

- Referring to self in the third person.

- Inappropriately ingratiating statement.

\footnotetext{
Gao v Ontario (Workplace Safety \& Insurance Board), 2014 ONSC 6497, 31 CPC (7th) 153 (SCJ) [Gao \#2] at para 18. Khan v Krylov \& Company LLP, 2017 ONCA 625, 2017 CarswellOnt 16235 [Khan] at para 12.

Scaduto, supra note 59 at para 8.

Beatty, supra note 63 at para 15.

Ibid at para 19.

Raji \#1, supra note 7 at para 8 .
} 
- Ultimatums.

- Threats of violence to self or others.

- Threats of violence directed at individuals or organizations. ${ }^{70}$

While these are helpful indicia in determining whether it is appropriate to allow a responding party to short-circuit the traditional motions and need for evidence and/or legal argument, as discussed in the next section, they are not strictly necessary. ${ }^{71}$ Moreover, as discussed below, they do not indicate, in and of themselves, that the plaintiff does not have a viable cause of action or that resort to Rule 2.1 is appropriate.

\section{Two Non-Determinative Criteria?}

A claim sufficiently devoid of merit can still be dismissed pursuant to Rule 2.1 even in the absence of indicia that a plaintiff will behave vexatiously. ${ }^{72}$ This is understandable. If the action is manifestly devoid of merit - such as a claim based upon the plaintiff's being upset that lifeguards allegedly chastised him for swimming too slowly in the fast lane of a pool ${ }^{73}$ - the proportionality principle cautions against further resources being expended. The second criterion is therefore a helpful guide that Rule 2.1 is appropriate, but judges retain discretion to use the Rule regardless.

The reverse does not hold. Two decisions of Myers $J$ illustrate why the second criterion is not a standalone basis to use Rule 2.1. In the first, a statement of claim alleged medical malpractice in a manner that was not obviously implausible. However, it was 400 pages long, and lacked a coherent narrative. When notice was ordered under Rule 2.1, the plaintiff began by explaining himself before insulting Myers $\mathrm{J}$ : "what started as a perfectly acceptable explanation quickly became a vexatious rant.",74 Rather than dismiss the claim pursuant to Rule 2.1, Myers J struck it pursuant to Rule 25.11, but permitted the plaintiff to submit a revised pleading. He also advised the plaintiff to obtain legal advice and directed him to a resource on how to draft pleadings. ${ }^{75}$

In the second, Myers $\mathrm{J}$ had similarly ordered a revised pleading be submitted. After the plaintiff submitted such a revised pleading, the defendant again sought to use Rule 2.1. Myers J declined to do so, but nonetheless noted that the Court should watch how the case unfolded. In doing so, he explained the difference between the two Rule 2.1 criteria:

In most Rule 2.1 cases the frivolous nature of the claim is clear and the real question is whether a motion to strike or to dismiss should be heard in court in the usual way or whether the motion should be dealt with under the attenuated process of Rule 2.1. Here, the issues are reversed. There is reason to fear that the plaintiff may have difficulty following the process of the court and his pleading does bear some hallmarks of a querulent litigant.

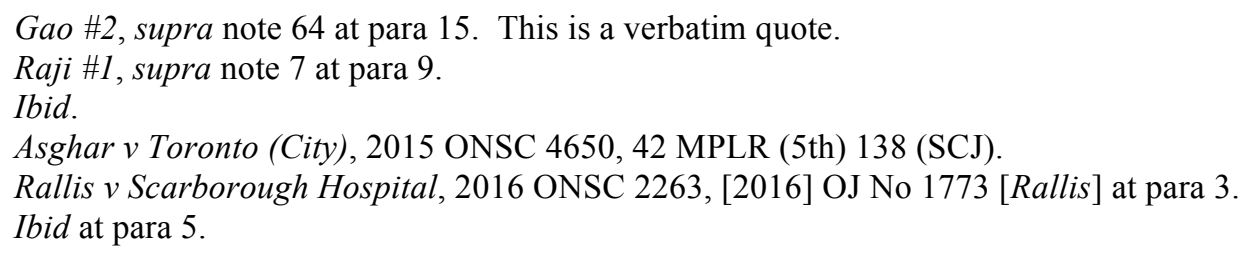


However, in my view, as he may well have a cause of action, [he] should have his day in court. $^{76}$

Although the defendants could quite understandably be concerned by how the plaintiffs in these two cases conducted themselves, given the interest in permitting even vexatious parties to have a day in court if they have a legitimate grievance, it would seem appropriate to not treat signs of abusiveness as a reason to use Rule 2.1, unless there truly is no viable cause of action.

\section{Dismissal Without Notice}

Rule 2.1's language contemplates that a court may depart from the requirement that notice be given to an affected party. And in thirteen cases, the notice requirement has been dispensed with. These rare instances fall into four categories:

(1) Five proceedings commenced in violation of vexatious litigant orders; ${ }^{77}$

(2) Four cases where the relief sought was not available in the Court where the proceeding was commenced (i.e., the Divisional Court when the Divisional Court could not provide the relief, or the Superior Court when an appeal was necessary) $;^{78}$

(3) Three attempts to re-litigate, one of which was brazenly acknowledged as such, ${ }^{79}$ with the other two being plaintiffs attempting to re-litigate matters already dismissed pursuant to Rule $2.1 ;{ }^{80}$ and

(4) A claim based on the allegation "that the military has implanted brainwashing devices in [the plaintiff and] hospital staff threw bugs on him [...] so he could be interrogated." 81

There are obvious natural justice concerns with dismissing a proceeding without giving a party an opportunity to be heard. This is codified in the common law procedural fairness principle audi alteram

76 Asghar $v$ Alon, supra note 61 at para 5.

77 Park v Short, 2015 ONSC 1292, [2015] OJ No 926 (SCJ); Park v Crossgate Legal Services, 2016 ONSC 4864, [2016] OJ No 4021 (SCJ); Reyes v Buhler, 2016 ONSC 5559, [2016] OJ No 4635 (SCJ) [Reyes v Buhler]; Reyes v Jocelyn, 2016 ONSC 5568, [2016] OJ No 4642 (SCJ) [Reyes v Jocelyn]; Reyes v Embry, 2016 ONSC 5558, [2016] OJ No 4636 (SCJ) [Reyes v Embry].

78 Coady v Law Society of Upper Canada, 2016 ONSC 7543, [2016] OJ No 6194 (Div Ct); Lin v Fluery, 2017 ONSC 3601, 2017 CarswellOnt 8926 (Div Ct), aff'd 2017 ONCA 695, 2017 CarswellOnt 13756 [Lin v Fluery]; Khan v 1806700 Ontario Inc, 2017 ONSC 3726, 2017 CarswellOnt 9122 (Div Ct); Lin v Rock, supra note 2.

79 D'Orazio v Ontario (Attorney General), 2016 ONSC 4893, [2016] OJ No 4031 (SCJ) [D'Orazio].

80 Lee v Future Bakery Ltd, 2016 ONSC 1764, [2016] OJ No 1266 (SCJ) [Lee v Future]; Nguyen v Bail, 2016 ONSC 2365, [2016] OJ No 1840 (SCJ).

81 Shafirovitch $v$ Scarborough Hospital, 2015 ONSC 7627, 85 CPC (7th) 149 (SCJ) [Shafirovitch]. 
partem. ${ }^{82}$ Hearings are important not only to ensure that justice be seen to be done, but also because it is likely to lead to better decision-making. ${ }^{83}$

Having said that, procedural fairness is a flexible concept. And in the case of Rule 2.1, all but the last case where a claim was dismissed without giving the plaintiff any opportunity to be heard outside his or her pleadings involved litigants who either: a) already had an opportunity to be heard and then proceeded to manifestly abuse the court system; or b) needed to be directed to another forum. As such, the opportunity to be heard was fulfilled. In the last case, Myers J reminded himself of the Court's duty towards selfrepresented litigants, and also noted that "there is perhaps a salutary effect to allow the litigant an opportunity to be heard." 84 But he then concluded:

I will not be disrespectful to the plaintiff by treating him with anything less than full candour. If the plaintiff believes that the military has implanted brainwashing devices in him and [...] hospital staff threw bugs on him to force itching so he could be interrogated, he needs assistance that a court cannot provide. The plaintiff may wish to consult with the Office of the Public Guardian and Trustee. ${ }^{85}$

I return to this dilemma about dispensing with the notice requirement below in Part IV.A.

The only appellate decision that reviewed the adequacy of notice in the court below is Van Sluytman $v$ Muskoka. ${ }^{86}$ The Court of Appeal took a substantive rather than formalistic approach to notice, noting that the appellant had clearly received formal notice in many of the eight actions he had commenced. Even if formal notice had not been sent in all, the Court was amply satisfied that no injustice had occurred as the purpose of notice - the right to be heard - was satisfied. The Court of Appeal also considered the notice requirement in Okel v Misheal, where it held that the form of notice could be flexible, as long as the party's right to be heard was fulfilled. ${ }^{87}$

\section{Types of Cases Dismissed Pursuant to Rule 2.1}

It is fair to say that in the vast majority of successful uses of the Rule, the lack of a cause of action is obvious. In Gao \#2, Myers J suggested seven attributes - six of them recognized as characteristics of vexatious litigants in case law under s 140 of the CJA - that would likely be apparent in cases where Rule

82 The Hon Louis LeBel, "Notes for an Address: Reflections on Natural Justice and Procedural Fairness in Canadian Administrative Law" (Feb 2013) 26 Can J Admin L \& Prac 51 at 53, based upon a presentation to the Continuing Legal Education Society of British Columbia Administrative Law Conference 2012 in Vancouver, British Columbia on Oct 26, 2012. While this specifically concerns administrative law, this principle applies to civil litigation as well: e.g. Ontario Provincial Police Commissionerv Mosher, 2015 ONCA 772, 340 OAC 311 at paras 60-63.

83 Jonathan Haidt, "Moral Psychology and the Law: How Intuitions Drive Reasoning, Judgment, and the Search for Evidence" (2013) 64:4 Ala L Rev 867 at 873, building on his work in Jonathan Haidt, The Righteous Mind: Why Good People Are Divided by Politics and Religion (New York: Pantheon Books, 2012); Justice Peter Lauwers, "Reflections on Charter Values" (Keynote Address Delivered at the Runnymede Society Law \& Freedom Conference, Hart House, University of Toronto, 12 Jan 2018), online: $<$ https:/www.youtube.com/watch?v=H5WTRCO-u9U $>$ at $\sim 18: 00-18: 20$.

84 Shafirovitch, supra note 81 at para 3.

85 Ibid at para 5.

86 Van Sluytman v Muskoka (District Municipality), 2018 ONCA 32, 2018 CarswellOnt 301.

872014 ONCA 699, [2014] OJ No 4842 [Okel] at para 10. 
2.1 is employed.$^{88}$ Three years into the Rule's history, many of these anticipated characteristics do describe multiple cases where Rule 2.1 was used to dismiss a claim:

(a) "Bringing multiple proceedings to try to re-determine an issue that has already been determined by a court of competent jurisdiction"; 89

(b) "Rolling forward grounds and issues from prior proceedings to repeat and supplement them in later proceedings including bringing proceedings against counsel who have acted for or against them in earlier proceedings" plaintiff's case ${ }^{91}$

(c) "Persistent pursuit of unsuccessful appeals"; 92

(d) "OPCA" $" 93$ litigants who frequently assert that neither statutory nor common law applies to them; ${ }^{94}$ and

(e) "bringing proceedings where no reasonable person would expect to obtain the relief sought," 95 with examples of this including:

i. A claim alleging a conspiracy to falsely implicate the plaintiff as a terrorist, conduct human experiments, and take over Africa, with Toronto-chambered judges of the Superior Court being part of this conspiracy; ${ }^{96}$

ii. An attempt to have the United States pay approximately $\$ 510$ billion American dollars in redemption of "bank bonds" that were obviously fake; ${ }^{97}$ and

iii. A request that Ontario provide the plaintiff with a job and fix his love life. ${ }^{98}$

iv. These are cases where Rule 2.1 was used to dismiss an action after notice, giving litigants the opportunity to explain themselves. The Rule indeed seems to be being applied to clear cases.

\section{Types of Cases Where Notice is Not Ordered}

There are rare cases where a defendant's proposed use of Rule 2.1 has been obviously inappropriate, attempting to bring in the merits through lengthy submissions ${ }^{99}$ or simply lacking any facial reason to

\footnotetext{
$88 \quad$ Supra note 64 at paras $14,16$.

89 Ibid at para 14(a), exemplified in, e.g. Hurontario Travel Centre v Ontario (Attorney General), 2015 ONSC 4246, [2015] OJ No 3469 (SCJ).

90 Gao \#2, ibid at para 14(b).

91 Raji v Myers, 2015 ONSC 4066, 75 CPC (7th) 115 (SCJ) [Raji v Myers].

92 Gao \#2, supra note 64 at para 14(c), exemplified in, e.g. El Zayat v Hausler, 2016 ONSC 6099, [2016] OJ No 4984 (Div $\mathrm{Ct}$ ).

93 “Organized Pseudolegal Commercial Argument”: see Meads v Meads, 2012 ABQB 571, 74 Alta LR (5th) 1.

94 Gao \#2, supra note 64 at para 16, exemplified in, e.g. Ali v Ford, 2014 ONSC 6665, [2014] OJ No 5426 (SCJ).

95 Gao \#2, ibid at para 14(f).

96 Raji v Myers, supra note 91.

97 Zeleny $v$ Canada, 2016 ONSC 7226, [2016] OJ No 6101 (SCJ).

98 Asghar v Ontario, supra note 1.

99 See e.g. Covenoho v Ceridian Canada, 2015 ONSC 2468, [2015] OJ No 1889 (SCJ); Kyriakopoulos v Lafontaine, 2015 ONSC 6067, [2015] OJ No 5029 (SCJ) [Kyriakopoulos]; Ramsarran v Assaly Asset Management Corp, 2017 ONSC
} 
believe the claim or motion is abusive. ${ }^{100}$ This has resulted in admonishments from the bench. ${ }^{101}$ More frequently, however, notice is not ordered when the claim appears badly drafted, ${ }^{102}$ excessively simple ${ }^{103}$ or likely to elicit a very strong defence, ${ }^{104}$ but where a plausible cause of action is nonetheless discernible. Another common example where notice is not ordered despite a judge's suspicions is where there is an allegation that the claim is an attempt to re-litigate, but this is not obvious. ${ }^{105}$ At other times, a plaintiff's actions appear tactically suspicious, but are not facially illegitimate or incompatible with a cause of action. The best example of this would be a late-breaking attempt by a defendant to bring a third party claim against the plaintiff's lawyer. ${ }^{106}$ There are good reasons to be apprehensive of such litigation tactics that may have an improper motive - but they are not necessarily incompatible with a legitimate cause of action, and Rule 2.1 is not the mechanism to address them.

\section{Family Law}

In Frick v Frick, ${ }^{107}$ the Court of Appeal cautioned against bringing the Rule into the family law context through Rule 1(8.2) of the Family Law Rules, which reads that a "court may strike out all or part of any document that may delay or make it difficult to have a fair trial or that is inflammatory, a waste of time, a nuisance or an abuse of the court process." ${ }^{108}$ Though family and civil litigation have much in common regarding the access to justice crisis, there are important distinguishing aspects. ${ }^{109}$ Moreover, the Rules of Civil Procedure do not generally directly apply in the family law context. In Court of Appeal family law appeals, however, where the Rules of Civil Procedure do apply, ${ }^{110}$ the Court of Appeal has used Rule 2.1. ${ }^{111}$ It has also been used in the Superior Court family law context when the plaintiff was subject to a vexatious litigant order. ${ }^{12}$

2394, [2017] OJ No 1937 (SCJ) [Ramsarran]; Carby-Samuels v Carby-Samuels, 2017 ONSC 2911, [2017] OJ No 2406 (SCJ).

100 See e.g., MacLeod v Hanrahan Youth Services, 2015 ONSC 8018, [2015] OJ No 6771 (SCJ) [Hanrahan].

101 Kyriakopoulos, supra note 99; Hanrahan, ibid.

102 Posadas $v$ Khan, 2015 ONSC 4077, 75 CPC (7th) 118 (SCJ) [Posadas]; Carby-Samuels v Carby-Samuels, 2016 ONSC 4974, [2016] OJ No 4188 (SCJ); 2222028 Ontario Inc v Adams, 2017 ONSC 690, [2017] OJ No 565 (SCJ) [“Adams"].

105 Bisumbule v Conway, 2016 ONSC 6138, [2016] OJ No 5209 (SCJ); Troncanada \& Associates v B2Gold Corp, 2016 ONSC 6271, [2016] OJ No 5190 (SCJ); Volynansky v Ontario (Attorney General), 2017 ONSC 1692, [2017] OJ No 1330 (Div Ct). 2016 ONCA 799, 132 OR (3d) 321 [Frick]

O Reg 114/99 [Family Law Rules].

Trevor CW Farrow, Civil Justice, Privatization, and Democracy (Toronto: University of Toronto Press, 2014) [Farrow, "Book"] at 71, fn 86; Mary-Jo Maur, Nicholas Bala \& Alexandra Terrana "Costs and the Changing Culture of Canadian Family Justice" (Feb 6, 2017) Queen's University Legal Research Paper No 087, online: SSRN $<$ url=https://ssrn.com/abstract=2919492>.

110 Family Law Rules, supra note 108, Rule 38.

111 Okel, supra note 87.

112 Hawkins v Schlosser, 2015 ONSC 646, [2015] OJ No 372 (SCJ). 


\section{CHARACTERISTICS OF THE CASE LAW}

\section{A. Overall numbers, courts, and success rates}

There were 190 reported cases indicating requests to use Rule 2.1 (whether by a judge, registrar, or responding party) between July 1, 2014 and June 30, 2017, an average of 63 per year. This compares to approximately 9,130 reported Superior Court/Divisional Court/Court of Appeal decisions per year. ${ }^{113}$ Many of the 190 Rule 2.1 decisions also have reported decisions for notice, disposition, and/or costs. The total numbers per year also include criminal and family cases, as well as cases that have multiple reported decisions per year. As such, it would appear that well over 1\% (likely much higher) of decided civil cases per year involve Rule 2.1. While far from the norm, this is not a trivial number. Dozens of cases a year is in any event not a small number, being well over double numbers for other procedural matters such as jurisdictional disputes. ${ }^{114}$ In the absence of Rule 2.1, one can only imagine what sort of mischief - ranging from wasted court time to unprincipled settlements - these cases would have caused.

In 162 of these 190 cases, the first use of Rule 2.1 was in the Superior Court, in 21 it was in the Divisional Court, and in 7 it was in the Court of Appeal. The chart below illustrates whether the request to dismiss a proceeding, or step therein, was granted, dismissed, or subject to another remedy, depending on the court in which the use of the Rule originated:

\section{TABLE 1: OVERALL RESULTS OF RULE 2.1 CASES}

\begin{tabular}{|c|c|c|c|c|}
\hline Disposition & $\begin{array}{l}\text { Number of } \\
\text { Cases }\end{array}$ & $\begin{array}{l}\text { Superior } \\
\text { Court }\end{array}$ & $\begin{array}{l}\text { Divisional } \\
\text { Court }\end{array}$ & $\begin{array}{l}\text { Court of } \\
\text { Appeal }\end{array}$ \\
\hline Granted & 136 & 111 & 19 & 6 \\
\hline After Notice & 121 & 99 & 16 & 6 \\
\hline Unclear About Notice & 2 & 2 & 0 & 0 \\
\hline Without Notice & 13 & 10 & 3 & 0 \\
\hline Partially Granted & 2 & 1 & 0 & 1 \\
\hline $\begin{array}{l}\text { Notice Ordered of Dismissal Being Considered but Final } \\
\text { Disposition Not Reported }\end{array}$ & 13 & 13 & 0 & 0 \\
\hline New Pleading Ordered & 1 & 1 & 0 & 0 \\
\hline Resolved After Claim Partially Withdrawn & 1 & 1 & 0 & 0 \\
\hline \multirow[b]{2}{*}{ No Notice Ordered } & 37 & 35 & 2 & 0 \\
\hline & 27 & 26 & 1 & 0 \\
\hline
\end{tabular}

113 Based on Feb 28, 2018 Westlaw searches, Sidhu v Knight, 2016 ONSC 8166, 2016 CarswellOnt 21037 (SCJ) appears to be the 2016 Divisional Court/Superior Court case with the "highest" number in its neutral citation, while DeMarco v Nicoletti Estate and Daboll, 2015 ONSC 8155, 2015 CarswellOnt 21018 (SCJ) appears to be the 2015 case with the "highest" number in its neutral citation. Based on a Feb 27, 2018 Westlaw search, JPB v CB, 2016 ONCA 996,2016 CarswellOnt 21847 appears to be the 2016 Court of Appeal decision with the "highest" number in its neutral citation, while Reischer, Re, 2015 ONCA 929, 344 OAC 132 appears to be the 2015 Court of Appeal decision with the "highest" number in its neutral citation.

114 Gerard J Kennedy, “Jurisdiction Motions and Access to Justice: An Ontario Tale” (2018) 55:1 Osgoode Hall LJ 79. 


\begin{tabular}{|l|l|l|l|l|l|}
\hline \multicolumn{2}{|l|}{ Disposition } & $\begin{array}{l}\text { Number of } \\
\text { Cases }\end{array}$ & $\begin{array}{l}\text { Superior } \\
\text { Court }\end{array}$ & $\begin{array}{l}\text { Divisional } \\
\text { Court }\end{array}$ & $\begin{array}{l}\text { Court of } \\
\text { Appeal }\end{array}$ \\
\hline & After Notice & 4 & 3 & 1 & 0 \\
\hline & In Context of Broader Motion & 3 & 3 & 0 & 0 \\
\hline & After Amended Pleading Served & 1 & 1 & 0 & 0 \\
\hline & After Appeal & 2 & 2 & 0 & 0 \\
\hline \multicolumn{1}{l|l}{ Total } & 190 & 162 & 21 & 7 \\
\hline
\end{tabular}

In 136 of 177 decisions where the result is known - over $75 \%$ of cases - Rule 2.1 was used to dismiss the action, or step therein. In four additional cases, the proceeding was partially dismissed, ${ }^{115}$ a new pleading was ordered, ${ }^{116}$ or the matter was resolved. ${ }^{117}$ That leaves 37 of 177 cases $-20.9 \%$ - where the attempted use was unsuccessful. This is an approximately four-to-one ratio of successful to unsuccessful uses. It is worth noting that in 27 of the 37 unsuccessful uses, notice was not ordered, and in an additional three, the Rule was only raised in the context of a broader motion, implying that little costs or delay resulted from the use of Rule 2.1 per se.

\section{B. Origin: Responding Party, Judge, or Registrar}

In 119 of the 190 cases, it appears clear or implicit that the responding party requested the use of Rule 2.1. In 14 cases, a judge appears to have raised the issue on his or her own initiative. In three, the registrar appears to have prompted the use of the Rule. In 54 cases, it was unclear how the matter came before the court. This could be suggestive that registrars and judges are being insufficiently proactive in using Rule 2.1. After all, the Rule's language suggests that a court is to use it "on its own initiative." 118 I return to a suggestion on how the registrars and judges could be more proactive below. However, in every case where the Court (whether by judge or registrar) prompted the use of the Rule, its use was successful. This minimization of inappropriate uses of the Rule is unquestionably positive from an access to justice perspective.

\section{Number of Appeals}

In 175 of the 190 cases - that is, over $90 \%$ - there was no reported appellate decision reviewing the decision whether to use Rule 2.1. Insofar as there were no substantive injustices in these cases, this low rate of appeals appears positive. I hasten to add that in all of the other fifteen cases, the appeal arose from a dismissal of the action. In thirteen of those cases, the lower court result was affirmed. Four of these decisions led to unsuccessful leave applications to the Supreme Court of Canada. ${ }^{119}$

115 Reyes v Esbin, 2015 ONSC 254, [2015] OJ No 97 (SCJ) [Reyes v Esbin]; Collins v Ontario, 2017 ONCA 317, [2017] OJ No 1982.

116 Rallis, supra note 74.

117 Clarke v Canada (Human Rights Commission), 2015 ONSC 2564, 2015 CarswellOnt 5611 (SCJ).

118 Rule 2.1.01(7).

119 Lin v Springboard, 2016 ONCA 787, [2016] OJ No 6072, leave to appeal ref'd, [2016] SCCA No 562; Lin v ICBC Vancouver Head Office, 2016 ONSC 3934, [2016] OJ No 3223 (Div Ct), aff'd 2016 ONCA 788, [2016] OJ 6071, leave to appeal ref'd, 2017 CarswellOnt 807 (SCC) [Lin v ICBC]; Ibrahim v Toronto Transit Commission, 2016 ONCA 234, [2016] OJ No 1631, leave to appeal ref'd, [2016] SCCA No 231; Scaduto, supra note 59. 
Only two cases had successful appeals. One was Frick, the case where the trial judge sought to import Rule 2.1 jurisprudence into the family law context. ${ }^{120}$ While the case's delay and costs were unfortunate for the parties, the Court of Appeal reached largely the same result as the trial judge, albeit by a different rationale. Moreover, it was valuable to clarify the applicability of Rule 2.1 jurisprudence in the family law context. $^{121}$ In the result, the negative access to justice consequences of the use of Rule 2.1 in Frick are minimal.

That leaves only one case (less than $1 \%$ of the total) where a civil action was dismissed pursuant to Rule 2.1 but this was overturned on appeal. Khan $v$ Krylov \& Company $L L P^{122}$ is a cautionary tale about judges becoming overzealous in using Rule 2.1. The case concerned an allegation that the defendants, the plaintiff's lawyers in a personal injury case, forged his signature on a settlement, misappropriated settlement funds, and did not properly explain the settlement to him. While serious allegations that would likely elicit a strong defence, the appellate judges noted that the facts as pled gave rise to a cause of action, and they also saw no signs that the plaintiff would act vexatiously in the litigation. Though noting that the statement of claim was short, and implying that some sort of summary procedure may be appropriate to resolve it, the Court of Appeal held that: "Once a pleading asserts a cause of action and does not bear the hallmarks of frivolous, vexatious or abusive litigation, resort to rule 2.1 is not appropriate as a means for bringing the action to an early end. The motion judge erred in truncating the normal process.",123

Though concerning, Khan is an outlier in terms of cases where the use of Rule 2.1 was granted. Rather, it bears similarity to cases where Myers J or Beaudoin J did not order notice pursuant to Rule $2.1{ }^{124}$ It also gave the Court of Appeal an opportunity to remind judges to be careful when using Rule 2.1. I cannot say that this single instance of the Court of Appeal needing to correct an overzealous Superior Court judge detracts, in and of itself, from Rule 2.1's effectiveness.

\section{Costs}

The ability to accurately calculate the costs incurred as a result of uses of Rule 2.1 is limited. This is because in 134 of the 190 cases, costs are unclear, usually because the decision is silent on the issue, ${ }^{125}$ the matter was referred to an assessment officer, ${ }^{126}$ or submissions were called for ${ }^{127}$ but the matter may have been settled. ${ }^{128}$ In some cases, it is clear that costs were to be assessed on a partial, ${ }^{129}$ substantial, ${ }^{130}$ or even full ${ }^{131}$ indemnity basis, but the quantum remains unclear. Moreover, 43 cases had no costs ordered. This is not surprising, given that defendants likely incurred minimal costs, Rule 2.1 is novel law, ${ }^{132}$ and

120 Supra Part II.C.

121 Housen v Nikolaisen, 2002 SCC 33, [2002] 2 SCR 235.

122 Khan, supra note 65.

123 Ibid at para 14.

124 See Part II.B.6.

125 See e.g. Stefanizzi v Ontario (Landlord and Tenant Board), 2015 ONSC 859, [2015] OJ No 562 (SCJ).

126 See e.g. Lee $v$ Future, supra note 80 at para 6.

127 See e.g. Markowa v Adamson Facial Cosmetic Surgery Inc, 2014 ONSC 6664, [2014] OJ No 5430 (SCJ).

128 A phenomenon discussed in, e.g. Kennedy, supra note 114.

129 See e.g. D'Orazio, supra note 79.

130 See e.g. Kadiri, supra note 57.

131 See e.g. Reyes $v$ Buhler, supra note 77.

132 A classic reason not to order costs: Pal v Powell (2009), 247 OAC 205 (Div Ct) [Pal] at paras 18-19, 22. 
there is good reason to suspect that several plaintiffs against whom the Rule is used are mentally ill and it would be unjust to make a costs order against them. ${ }^{133}$ An additional case had no costs ordered against some defendants while the costs against the others are unclear. ${ }^{134}$ One case seems inapposite because the costs award was clearly related to issues other than the unsuccessful attempt to invoke Rule $2.1{ }^{135}$ This comes to a total of 179 out of 190 cases shedding no real light on the costs actually incurred.

However, the eleven cases with reported costs (appearing in Appendix C) are nonetheless interesting. The average size of the nine first instance costs awards is $\$ 6,133.79$. But Irmya $v$ Mijovick is an extreme outlier, nearly four times the quantum of the next highest award. The average excluding that case is $\$ 3,127.04$, which is still higher than the median of $\$ 2,256.39$. The average of the three appellate costs awards is $\$ 8,561$. Again, however, there is an extreme outlier in Chalupnicek, which is nearly six times the size of the next award. The average of the other two is $\$ 2,500$, not far from the median of all three that is $\$ 3,000$. Accordingly, while the small sample size being drawn from must be acknowledged, the typical costs awards appear in the $\$ 3,000$ range for a case without an appeal, and about double that for a case with an appeal.

Costs awards typically represent only half of costs actually incurred. ${ }^{136}$ Even recognizing that, however, compared to other preliminary motions, the costs of which have been analyzed (e.g., jurisdiction motions), these costs are very low. A recent analysis of jurisdiction motions suggests that "each party in a non-class action can reasonably expect to spend approximately $\$ 30,000-\$ 45,000$ on a jurisdiction motion, and $\$ 60,000-\$ 75,000$ if there is an appeal." 137 And unlike jurisdiction motions, Rule 2.1 attempts to resolve a dispute on its merits. The costs to do so appear very reasonable, according with the proportionality principle.

\section{E. Time Delay Caused by Rule 2.1}

For the purposes of calculating delay, I did not include instances where the following occurred, as they shed little if any light on delay caused by Rule 2.1:

- where Rule 2.1 was raised but not used in the context of a broader motion;

- where notice was ordered but the final disposition is not reported; or

- if the use was granted but it was unclear whether notice was ordered.

Given that cases generally only note when notice was ordered (rather than when the matter was brought to a judge's attention), delay is calculated from the date that notice is ordered. This appears to be very

133 Shafirovitch, supra note 81; the unwellness of a party can be a reason not to order costs: Pal, ibid at paras 21-22.

134 Goralczyk v Beer Store, 2016 ONSC 2265, [2016] OJ No 1763 [Goralczyk \#1] compared to Goralczyk v Beer Store, 2016 ONSC 4416, [2016] OJ No 3597 (SCJ).

135 Fine, supra note 49.

136 See e.g. P Scott Horne, “The Privatization of Justice in Québec's Draft Bill to Enact the New Code of Civil Procedure: A Critical Evaluation" (2013) 18 Appeal 55 at 61, citing Riddell v Conservative Party of Canada, 2007 CarswellOnt 4202, [2007] OJ No 2577 (SCJ) at para 90; cited in Kennedy, supra note 114, fn 60.

137 Kennedy, ibid. 
shortly after matters are brought to a judge's attention. ${ }^{138}$ If the date where notice was ordered is not clear, I could not calculate delay. In Appendix D, I accordingly amend the above chart on results to include delay.

Of the 121 cases where the motion was granted after notice, delay can be calculated on 102 . The average delay is 45 days: 45 in 99 Superior Court decisions, 31 in 8 Divisional Court decisions, and 126 in 2 Court of Appeal decisions. ${ }^{139}$ Where appeals occurred, the average delay was 232 days. And when a Supreme Court leave application was made, the average delay was 338 days.

I separate my analysis of delay in cases where the use of Rule 2.1 was granted from delay where it was not for the following two reasons. First, the access to justice consequences of the delay in cases where the Rule's use is successful are very different from those where the use is unsuccessful. The former is the delay required to resolve the action finally, while the latter impedes the plaintiff's ability to bring his or her case promptly. The latter is accordingly much more problematic from an access to justice perspective. Second, the sample size where delay is quantifiable in cases where the proposed use of Rule 2.1 was unsuccessful is very small - only five cases. The measure of the delay in those five cases is lengthy - 126 days at the trial level alone. For these plaintiffs, the Rule was a severe access to justice obstacle. (Admittedly, in one of them an amended pleading was ordered, which was to all parties' benefit. ${ }^{140}$ ) But it is difficult to draw many normative lessons from this small sample size. In the vast majority of cases where the proposed use of the Rule was unsuccessful, judges have simply elected not to issue notice. Having the opposing party suggest that Rule 2.1 be employed in these circumstances is doubtless annoying for plaintiffs, but it seems to have minimal access to justice consequences, beyond the plaintiff's annoyance and the judge's time. I turn to suggestions on how to mitigate these access to justice impediments in Part IV, below.

\section{F. Self-Represented Litigants?}

It was not always clear from the decisions if parties were represented by counsel. At times, I inferred that a litigant was self-represented: for example, if the judge referred to the plaintiff making submissions when normally counsel would be referred to as making submissions. ${ }^{141}$ Another example where I assumed a litigant was self-represented would be if the judge referred to submissions as unintelligible; ${ }^{142}$ it seemed a fair inference in these circumstances that a lawyer did not draft the claim. However, I erred on the side of agnosticism in this respect.

Of the 190 decisions, all parties had counsel in only nine cases. 144 appear to have been instances where Rule 2.1 was sought to be used against self-represented litigants, though in one of those, the plaintiff

138 In Asghar v Toronto (City) Police Services Board, 2016 ONSC 4844, [2016] OJ No 4028 (SCJ), a rare instance where the judge notes the date of the defendant's letter, the delay between the date of the defendant's letter to the ordering of notice is nine days.

139 It is of course difficult to make conclusions based on the small samples of Court of Appeal and Divisional Court decisions. Proper statistical analysis (which I am not qualified to conduct independently) may be appropriate after more years of use of the Rule. Rallis, supra note 74.

141 See e.g. Asghar v Avepoint Toronto, 2015 ONSC 5544, [2015] OJ No 4611 (SCJ).

142 See e.g. Brown v Fred Victor Organization, 2015 ONSC 3516, [2015] OJ No 3428 (SCJ). 
was a lawyer himself. ${ }^{143}$ At $75 \%$, this is in line with Macfarlane's observation of "some lower level civil courts reporting more than $70 \%$ of litigants as self-represented." ${ }^{\prime 144}$ In an additional three-to-five of these cases, the litigant had a law degree. ${ }^{145}$ In one case, someone purported to act as agent for the plaintiff but did not appear to be a licensed lawyer. ${ }^{146}$ In the other 38 decisions, it was unclear whether there were selfrepresented parties.

It is striking that attempts to use Rule 2.1 were unsuccessful in seven of the cases where all sides had counsel. ${ }^{147}$ The $22 \%$ success rate ${ }^{148}$ is much lower than the typical rate of $75-80 \%$. This could indicate that the Rule is being used unfairly against self-represented litigants. However, it is also possible hopefully likelier - that lawyers are less likely to take on frivolous cases. After all, lawyers in Ontario swear an oath or make an affirmation upon being called to the bar that they will not commence claims on frivolous pretences. ${ }^{149}$ Ultimately, though the comparatively high success rate of Rule 2.1 against selfrepresented litigants could be concerning, as long as judges remain cognizant of their duties to assist selfrepresented litigants, a matter I return to below, there are not necessarily significant access to justice concerns with Rule 2.1 for this reason alone.

\section{G. "Frequent Flyers"}

Twenty individuals represent, cumulatively, at least 63 of the 153 proposed uses of Rule 2.1 that were not dismissed - over $40 \%$. Given that most of these individuals commenced their different actions against different defendants, it illustrates the utility of Rule 2.1 in not forcing multiple defendants into bringing motions and/or vexatious litigant applications. And this is merely among those cases that were reported many additional cases these individuals have commenced appear unreported. ${ }^{150}$ I return to a potential way to monitor these individuals below.

143 Posadas, supra note 102.

144 Julie Macfarlane, “The National Self-Represented Litigants Project: Identifying and Meeting the Needs of SelfRepresented Litigants - Final Report" (Windsor, ON: The National Self-Represented Litigants Project, the University of Windsor, May 2013) [Macfarlane, "Main Report"] at 34.

145 Reyes $v$ Buhler, supra note 77; Reyes $v$ KL, supra note 50; Reyes $v$ Esbin, supra note 115; Reyes $v$ Jocelyn, supra note 77; Reyes v Embry, supra note 77.

146 Adams, supra note 102.

147 Haidari v Sedeghi-Pour, 2015 ONSC 2904, 73 CPC (7th) 191 (SCJ); Craven v Chmura (2015), unreported, but referred to in Craven v Chmura, 2015 ONSC 4843, [2015] OJ No 4088 (SCJ); Kyriakopoulos, supra note 99; Charendoff, supra note 106; Ramsarran, supra note 99; Caliciuri, supra note 49; Frick, supra note 107.

148 Chalupnicek v Children's Aid Society of Ottawa, 2017 ONSC 1278, 2017 CarswellOnt 272 (Div Ct) [Chalupnicek]; Gates $v$ Humane Society of Canada for the Protection of Animals and the Environment (cob The Humane Society of Canada), 2016 ONSC 5345, [2016] OJ No 4424 (Div Ct); Hoang v Mann Engineering Ltd, 2015 ONCA 838, [2015] OJ No 6316 [Hoang].

149 Law Society of Ontario, By-Law 4, Licensing, s 21, online: $<$ http://www.lsuc.on.ca.ezproxy.library.yorku.ca/WorkArea/DownloadAsset.aspx?id=2147485805>.

150 Emily Mathieu \& Jesse McLean, "Vexatious litigant' continues to have her days in court," The Toronto Star (26 Nov 2016), online: <url=https://www.thestar.com/news/gta/2016/11/26/vexatious-litigant-continues-to-have-her-days-incourt.html>; Lin v ICBC Vancouver Head Office, 2016 ONSC 3934, [2016] OJ No 3223 (Div Ct), aff'd 2016 ONCA 788, [2016] OJ 6071, leave to appeal ref'd, 2017 CarswellOnt 807 (SCC). 


\section{WAYS FORWARD}

As should be obvious, I view Rule 2.1 to have been fundamentally a positive addition to Ontario's Rules, resolving particular types of actions on their merits in a timely and cost-effective matter. Though a party's "opportunity to be heard" may not be as in-depth as is traditional, procedural fairness is a flexible concept. The dismissal of a claim without a trial, much less the dismissal without a hearing, was historically seen as the quintessential example of a procedural injustice. ${ }^{151}$ But post-Hryniak, and bearing the principle of proportionality in mind, we have recognized that that is not always necessary - other, less formal procedures can fulfill the requirement of procedural fairness. ${ }^{152}$ While the use of letters instead of formal motions may be seen to compromise the open court principle, that principle can yield to various other societal concerns ${ }^{153}$ and, more importantly, formally reported decisions leave the open court principle largely respected. It should be borne in mind that administrative law - which shares many of the same concerns as civil litigation regarding procedural fairness and audi alteram partem ${ }^{154}$ - frequently holds informal/written procedures to be sufficient to dismiss claims. ${ }^{155}$

Having said that, lessons should still be critically drawn. I begin this section by suggesting how the Rule should be interpreted going forward in light of successes and failures in its application to date. I argue that the Rule needs to continue to be interpreted restrictively yet applied robustly when appropriate. I also make specific suggestions regarding cases where the plaintiff appears to be attempting to re-litigate a proceeding, where a cause of action appears buried in an otherwise obviously abusive pleading, the possibility of a standard form for requesting parties to use, and the dangers inherent in dispensing with notice. Having established these considerations regarding the interpretation of the Rule from a doctrinal perspective, I then address three specific lessons that could be drawn from the application of Rule 2.1 from an institutional perspective. First, I make suggestions regarding the potential for more proactive policing of the Court's docket by judges and registrars. I then turn to what the experience of Rule 2.1 says regarding the potential of specialized decision-makers to facilitate access to justice. Finally, I make some comments regarding the ethics of using Rule 2.1 given that it is likely to be used disproportionately against self-represented litigants.

151 Walker, supra note 5 at 697, quoting Irving Ungerman Ltd v Galanis (1991), 4 OR (3d) 545 at 550-51.

152 Shantona Chaudhary, "Hryniak v. Mauldin: The Supreme Court issues a clarion call for civil justice reform" (Winter 2014) 33 Adv J No 3 (praising Hryniak); Farrow, “2012," supra note 13 (concerning proportionality); MacKenzie, supra note 5 (also praising Hryniak).

153 See e.g., $R v N S, 2012$ SCC 72, [2012] 3 SCR 726 (admittedly in a different context).

154 LeBel, supra note 82 at 53.

155 Noted in the introduction of Freya Kristjanson \& Sharon Naipul, “Active Adjudication or Entering the Arena: How Much is Too Much?” (2011) 24 Can J Admin L \& Prac 201; L'Heureux-Dubé J contemplated written submissions satisfying procedural fairness in Baker v Canada (Minister of Citizenship \& Immigration), [1999] 2 SCR 817 at para 33: it "cannot be said that an oral hearing is always necessary to ensure a fair hearing and consideration of the issues involved." 


\section{A. How the Rule Should Be Interpreted Going Forward}

\section{In Favour of a Restrictive Standard, Robustly Applied}

By its words, Rule 2.1 is meant to apply to litigation that is "on its face" frivolous, vexatious, and/or abusive. Courts have been rigorous in enforcing this requirement, even in cases where a small amount of legal argument or evidence could make the "certain to fail" nature of the litigation apparent. This standard is appropriate, partially because it accords with the Rule's words, which are always where an analysis of a statute or regulation's meaning begins, ${ }^{156}$ and also because Rule 2.1 is meant to apply very summarily, and evidence and argument would defeat that purpose.

In this sense, Rule 2.1 should not be conflated with Rules 21 or 25.11 . These rules have indispensable roles to play in the resolution of actions in certain cases, weeding out hopeless cases and clearing courts' dockets for all members of the public to use. ${ }^{157}$ Though strong cases can be made, such as those put forward by Stephen Pitel and Matthew Lerner, that such rules should be more broadly interpreted to permit the resolution of questions of law, ${ }^{158}$ this should not bleed into Rule 2.1. The common law is based on the premise that adversarial argument is likely to lead to a better resolution of questions of law - a premise that modern psychology has shown to be well-founded. ${ }^{159}$ While the virtues of summary procedures are manifold, ${ }^{160}$ Rule 2.1 is the most summary of all, dispensing with evidence, discovery, and legal argument. Restricting its use to the "clearest of cases" is therefore appropriate from a policy perspective. If the law needs to be explained, a factum is necessary and Rule 2.1 is inappropriate. Therefore, judges should be reluctant to order notice if there is even a whiff of a cause of action. The cases where Rule 2.1 has been an obvious access to justice hindrance are instances where notice was ordered and then the judge declined to use the Rule after receiving the plaintiff's submissions. Obviously, if a plaintiff explains, though submissions, that his or her action is not abusive, a judge should not dismiss it - that is the purpose of notice. ${ }^{161}$ But no plaintiff should be put in that situation unnecessarily.

Although Rule 2.1 contemplates submissions from responding parties, judges issuing notice should consider whether they are truly necessary. This is not to suggest that a court should never reach out to a responding party for representations if the goal is to help redirect the plaintiff to an appropriate, potentially non-legal, forum for assistance. For instance, the ability to reach out to responding counsel to discern whether "something horrible [i]s indeed happening" that would require intervention, albeit not in the civil courts, seems eminently reasonable. ${ }^{162}$ Generally, however, a responding party will have little to add about whether a pleading is "on its face" abusive, making responding submissions a waste of resources.

In this vein, one decision where Rule 2.1 was used to dismiss a claim arguably seemed inappropriate. In Beatty, ${ }^{163}$ the plaintiff sought to sue, among other parties, the Office of the Children's Lawyer [OCL]

\footnotetext{
156 Ruth Sullivan, Sullivan on the Construction of Statutes, 6th ed (Toronto: Butterworths, 2014) at $\S 23.81$, quoting Re Rizzo \& Rizzo Shoes Ltd, [1998] 1 SCR 27 at para 35.

$157 R$ v Imperial Tobacco Canada Ltd, 2011 SCC 42, [2011] 3 SCR 45 at paras 18-19.

158 See e.g. Pitel \& Lerner, supra note 19; Gerard J Kennedy \& Mary Angela Rowe, “Tanudjaja v. Canada (Attorney General): Distinguishing Injusticiability and Deference on Motions to Strike” (2015) 44 Adv Q 391.

159 See e.g. Haidt, supra note 83; Lauwers, supra note 83.

160 See e.g. Pitel \& Lerner, supra 19; Hryniak, supra note 6; MacKenzie, supra note 5.

161 See Part III.E, supra.

162 Kadiri, supra note 57 at para 7.

163 Supra note 63.
} 
for, among other things, many acts for which the OCL is prima facie immune under the CJA. ${ }^{164}$ The claim bore many hallmarks of abusive litigation and was also an attempt to re-litigate some matters raised in the pleading. ${ }^{165}$ The issue of immunity was the only issue that gave the judge pause in concluding that there was no valid cause of action buried within the claim as the OCL's immunity is not absolute. He engaged in eleven paragraphs of legal analysis to determine that no applicable exceptions applied, concluding that aspects of the pleading that could suggest an exception applied appeared to have been inserted for colour. ${ }^{166}$ With respect, this amount of legal analysis leads one to wonder if the claim was actually "on its face" frivolous, vexatious, or abusive; read generously, there appeared to be a (weak) cause of action lurking in the pleading and a pleadings motion may have been more appropriate.

Given that this is the only claim I have read where I felt the employment of Rule 2.1 was inappropriate, and given that no substantive injustice seems to have occurred, this does not detract from the overall effectiveness of the Rule in enhancing access to justice. However, it does appear to be an instance where Rule 2.1 was arguably, albeit understandably, used to "shortcut" proper procedure where adversarial argument would have been helpful.

\section{The "Attempt to Re-Litigate" Exception}

An exception to the "on its face" requirement is appropriate where a pleading may contain a cause of action, but the proceeding is an obvious attempt to re-litigate issues that have already been finally determined. Traditionally, attempts to re-litigate issues had to be addressed by either a vexatious litigant proceeding under s 140 of the CJA, ${ }^{167}$ or a motion under Rule 21 or $25.11 .{ }^{168}$ As noted above in Section I.B, these are time-consuming and expensive. It is unjust to force a defendant, having already participated in litigation that determined an issue, to do so again. As such, it would appear appropriate to allow a responding party to direct a one sentence explanation letter to the Court, merely pointing in the direction of the release or past decision. If there is any ambiguity about the binding nature of the release or decision, as there sometimes will be, ${ }^{169}$ the Court should decline to use Rule 2.1. But if the pleading, when combined with the precedent or release, leads to the abusiveness of the new pleading being apparent "on its face," Rule 2.1 is appropriate. After all, attempting to re-litigate issues is a hallmark of abusive litigation. ${ }^{170}$

\section{Cause of Action Buried in an Abusive Pleading}

When a pleading potentially contains a scintilla of a cause of action, but is otherwise obviously abusive, ${ }^{171}$ it would appear unfair to force the defendant to respond to obviously inappropriate and/or irrelevant material. It is also not in a plaintiff's best interest to allow him or her to make irrelevant

164 CJA, supra note 9, s 142.

165 Beatty, supra note 63 at para 28.

166 Ibid at paras 36-46.

167 See e.g. Pagourov, supra note 38.

168 See e.g. Power Tax Corp v Millar, 2013 ONSC 135, 113 OR (3d) 502 (SCJ).

169 See supra note 105.

170 Gao \#2, supra note 64 at para 15; Behn, supra note 27 at para 40, quoting Canam, supra note 28 at para 56.

171 Rallis, supra note 74, was, as discussed above, an instance where the plaintiff made a vexatious rant in the context of claiming, without obvious implausibility, medical malpractice. 
arguments that are destined to fail. ${ }^{172}$ As such, judicial intervention may be warranted as at least parts of the proceeding are "on their face" abusive. However, the appropriate remedy in these circumstances would be to order that a new pleading be delivered. ${ }^{173}$ This preserves any legitimate interest of the plaintiff, but makes it clear that he or she cannot proceed in an abusive fashion. The case law has already illustrated that this can be a valuable use of Rule 2.1. ${ }^{174}$

\section{A Standard Form?}

A primary cause of unsuccessful uses of Rule 2.1 is attempts by responding parties to explain why a proceeding is abusive, whether through obviously inappropriate legal argument and attempts to put unsworn evidence before the Court; ${ }^{175}$ or more understandable, but still inappropriate, explanations of the allegedly vexatious party's past behaviour. ${ }^{176}$ These concerns could potentially be addressed by a standard form that any request to use Rule 2.1 would have to follow. Such a form could integrate all potential nuances to the "on its face" requirement very simply. An example appears in Appendix E. I express no strong opinion on whether such a form would be desirable. The improper uses of the Rule are rare enough that asking parties to submit such a form may be needless complication to the simple procedure that is Rule 2.1. The civil justice system does not suffer from a lack of paperwork. Having said that, a standard form could also streamline all cases under the Rule, and prevent improper uses of the Rule early on in the process. As such, a pilot project in Toronto - a Superior Court jurisdiction with many practice directions for uses of particular elements of procedural law ${ }^{177}$ - may be an experiment worth considering.

\section{Dispensing with Notice}

Some internal angst seems to be apparent among Rule 2.1 judges about when it is appropriate to dispense with the notice requirement. The common law has always emphasized that some type of hearing before a decision is made affecting one's legal interests is an essential part of fairness. Fortescue $J$ famously wrote in Dr. Bentley's Case in 1723, that "even God himself did not pass sentence upon Adam before he was called upon to make his defence [...] And the same question was put to Eve also." ${ }^{, 178}$ But submissions filed in response to notice ordered pursuant to Rule 2.1 can generally encompass the party's opportunity to be heard. ${ }^{179}$

In thirteen cases, the notice requirement was dispensed with, usually because the proceeding was commenced in violation of a vexatious litigant order, had manifestly been brought in the wrong court, and/or was an obvious attempt to re-litigate. I am inclined to agree that ordering notice in cases such as these is neither necessary nor appropriate. Most importantly, the purpose of notice - the opportunity to be heard by a judge - had already been fulfilled or could be fulfilled in another venue. Moreover, the wording

Shafirovitch, supra note 81 at paras 3, 5.

173 Rallis, supra note 74.

174 Ibid; Asghar v Alon, supra note 61.

175 Ramlall v Jahir Ullah Pharmacy Inc \#1333, 2016 ONSC 2705, [2016] OJ No 2139 (SCJ) at para 3.

176 Raji \#1, supra note 7.

177 Ontario Superior Court of Justice, "Practice Directions and Policies: Toronto," online: Ontario Courts $<\mathrm{http}: / /$ www.ontariocourts.ca/scj/practice/practice-directions/toronto/>.

$178 R v$ Chancellor, Masters and Scholars of the University of Cambridge (Dr Bentley's Case) (1723) 1 Str 557 at 567.

179 This is most obviously apparent in administrative law: LeBel, supra note 82. 
of Rule 2.1 prescribes notice "unless the Court orders otherwise." Given that the possibility of dispensing with notice is therefore contemplated, this minimizes the rule of law concerns that come with dispensing with it. ${ }^{180}$ Finally, in many situations, it was in the moving party's own best interest that they be redirected to a new procedure as soon as possible - particularly, the instances where the matter had been brought in the wrong Court ${ }^{181}$ or time was ticking on an appeal period. ${ }^{182}$

The one case where this was most difficult - and where Myers J appeared to have the greatest struggle - was Shafirovitch, where the plaintiff alleged that the military had implanted brainwashing devices in him, and hospital staff threw bugs on him so he could be interrogated. If true, these facts would amount to a cause of action. But it also seems appropriate to take judicial notice that these facts would not have occurred, ${ }^{183}$ and the plaintiff was therefore behaving vexatiously deliberately or, more likely, was mentally ill. Myers J held that "realistically, there is nothing" the plaintiff could have said that would have led to his not dismissing the action. ${ }^{184}$ He then compassionately referred the plaintiff to the Public Guardian and Trustee. ${ }^{185}$ This was understandable, especially as it may have appeared disingenuous to have allowed the plaintiff to have made submissions in these circumstances. ${ }^{186}$ However, the "right to be heard" principle is so important in the common law, and the precedent of allowing judges to comment on the merits of a dispute without any submissions so potentially dangerous, that I would be inclined to mandate submissions in these circumstances. This would leave the "no submissions" cases confined to instances where the plaintiffs have either already had an opportunity to be head, or are certain to have that opportunity in another venue. That Shafirovitch was the only case where notice was dispensed with that did not fall into these categories suggests that the costs of mandating notice in cases such as Shafirovitch are not great, while also ensuring that justice is seen to be done.

\section{B. A More Active Role for the Court}

Rule 2.1's wording suggests the Court itself is to be the primary gatekeeper on its use. However, the Rule is almost always used as a result of a responding party's request. To some extent, this could indicate understandable risk-averseness from both common law judges trained to be passive listeners, as well as registrars who are not meant to be decision-makers. The registrars are likely the primary reason the Court seldom employs Rule 2.1 without a responding party's request. After all, registrars see the originating

180 Ignoring a statute or regulation's language is antithetical to the rule of law, though how this principle is applied in marginal cases is of course contestable: see, e.g. Stéphane Beaulac, "Parliamentary Debates in Statutory Interpretation: A Question of Admissibility or Weight" (Aug, 1998) 43 McGill LJ 287 at 322.

181 The access to justice implications of Ontario having multiple appellate venues is an important topic for another day.

182 Lin $v$ Rock, supra note 2 at para 12.

183 Judicial notice is available when something is "either (1) so notorious or generally accepted as not to be the subject of debate among reasonable persons, or (2) capable of immediate and accurate demonstration by resort to readily accessible sources of indisputable accuracy": $R v$ Spence, 2005 SCC 71, [2005] 3 SCR 458 at para 53, quoting $R v$ Find, 2001 SCC 32 , [2001] 1 SCR 863 at para 48. That Canadian hospitals do not throw bugs upon individuals so that they can be interrogated appears to fall within the first branch. Even if the allegation that the military implanting brainwashing devices in persons does not fall within this category (though I am inclined to the view that it does), it is difficult to fathom how the plaintiff would or could have proven such an allegation.

184

185

186 .

Myers J's concern in Shafirovitch, ibid at para 3. 
documents when they are filed, whereas judges seldom do. This reticence has advantages - Rule 2.1 is an extremely powerful tool and there have been no "false positives" when registrars or judges commenced the Rule 2.1 process unprompted.

While caution is the side on which the registrars should likely err, simple training to look for obviously vexatious actions could be helpful, also assisting registrars in their duties under Rule 2.1.01(7). As Myers $\mathrm{J}$ once told a Continuing Professional Development class, he tells registrars that "if you get a claim and it's written in crayon, call me." ${ }^{\text {187 }}$ This comment could be interpreted flippantly but his jurisprudence indicates that he is willing to give the benefit of the doubt to any pleading with even a semblance of a cause of action.

Two practical suggestions may be of assistance. First, registrars could have a list of persons against whom Rule 2.1 orders have been made. Such persons should be able to file pleadings (unless subject to a vexatious litigant order) but these pleadings could be sent to a judge to review. While it is possible that these persons could bring a legitimate proceeding, given that more than $40 \%$ of proper uses of Rule 2.1 are the result of "frequent fliers," a simple review of their pleadings by a judge appears prudent. Given the minimal time investment in having a judge review a single originating document, such a review could have minimal costs but substantial savings to all parties.

Second, in order to ensure that such a list is as comprehensive as possible, judges should report their decisions to use Rule 2.1. There are several good reasons to believe that this is not always done. First, I discovered many instances where one, but not all, of an appeal, order of notice, and/or first disposition was reported. Second, the Toronto Star uncovered, after an investigation, that one individual has commenced vastly more proceedings than have been reported. ${ }^{188}$ Third, Sachs J referred to another individual having commenced fifteen proceedings in the Divisional Court in a period of less than three years, most of which were not reported. ${ }^{189}$

\section{Specialized Decision-Makers}

Specialized decision-makers can become familiar with the substantive law and procedure related to a particular area of law. In addition to increasing efficiency and leading to a more consistent jurisprudence, this is also likely to minimize errors. ${ }^{190}$ This has been particularly discussed in the family law context, ${ }^{191}$ but has been considered in the civil context as well. For example, the Toronto Commercial List has been praised as a specialized group of Superior Court judges working in a particular context, and in doing so improving access to justice. ${ }^{192}$

187 Made at Ontario Bar Association Young Lawyers Division, Evening Reception with The Honourable Mr. Justice Fred Myers, March 22, 2016; reported in Gerard J Kennedy, "Justice for Some" The Walrus (Nov 2017) 47 at 53.

188 Mathieu \& McLean, supra note 150, contra the five cases reported in Appendix B.

189 Lin v ICBC, supra note 119, contra the cases actually reported in the Divisional Court, in Appendix B.

190 Kennedy, supra note 114 at 105-106.

191 See Kennedy, ibid; Action Committee on Access to Justice in Civil and Family Matters, Access to Civil \& Family Justice: A Roadmap for Change (Ottawa: Action Committee on Access to Justice in Civil and Family Matters, Oct 2013) at 16: Canadian Forum for Civil Justice, online: $<$ http:// www.cfcj-

fcjc.org/sites/default/files/docs/2013/AC_Report_English_Final.pdf>, cited in Kennedy, ibid at 106.

192 See e.g. Warren K Winkler, “The Vanishing Trial” (Autumn 2008) 27:2 Advocates' Soc J 3 at 4, cited in Kennedy, ibid at 106. 
Myers J, as well as, to a lesser extent, Beaudoin and Nordheimer JJ, have had a disproportionate influence on the development of Rule 2.1. Myers $\mathrm{J}$ was designated as the Toronto judge responsible for Rule 2.1 shortly after his appointment to the bench. ${ }^{193}$ Of the 162 Superior Court decisions, 96 were decided by Myers J, and 24 were decided by Beaudoin J. This represents nearly $75 \%$ of the Superior Court decisions. Nordheimer J decided 13 of the 21 Divisional Court decisions prior to his elevation to the Court of Appeal. This appears to have resulted in a streamlined approach to the use of Rule 2.1, leading to predictability, relatively few improper uses, and very few successful appeals. Although Myers J wrote vastly more reported decisions, the fact that Beaudoin and Nordheimer JJ also wrote a substantial minority of decisions mitigated the risk that the idiosyncratic views of a single judge would have disproportionate influence. Having a limited group of judges - particularly in jurisdictions such as Toronto and Ottawa review cases such as these therefore appears to be a beneficial idea from the perspective of access to justice. None of Justices Myers, Beaudoin, nor Nordheimer wrote either of the two successfully appealed decisions. ${ }^{194}$

There are disadvantages to specialization. For instance, specialization can lead to a judge's burn-out due to lack of exposure to new issues. Specialization can also lead to a resistance to considering new ideas. ${ }^{195}$ However, these risks must be weighed against the benefits of specialization. In any event, they can be mitigated by "rotating" the specialized judges, which occurs in the context of class actions in Toronto. ${ }^{196}$ Ultimately, therefore, Rule 2.1 appears to be an instance where specialization has been a success. Not only should this be continued in this context, this could potentially be applied to other areas of civil litigation.

\section{Dealing with Self-Represented Litigants and the Mentally Ill}

Before giving an unequivocal endorsement to Rule 2.1, it is important to consider the ethical implications of the Rule. It has now become trite law that Rule 2.1 is "not for close cases." 197 It is easy to imagine how Rule 2.1, given its extremely summary nature without in-face court time, can be used against disadvantaged, frequently self-represented, persons. As the National Self-Represented Litigants Project has noted, self-represented litigants frequently do not understand summary procedures and can feel ambushed when responding to them. ${ }^{198}$ The above analysis indicates that the Rule is more likely to be

193 Brown v Loblaws Companies Limited, 2015 ONSC 7629, [2015] OJ No 6394 at para 4.

194 Frick, supra note 107; Khan, supra note 65.

195 See e.g. Freeda Steel, “The Unified Family Court - Ten Years Later" (1996) 24 Man LJ 381 at 388.

196 Traditionally, three judges serve in this respect, though that was reduced to two after Strathy J was elevated to the Court of Appeal: Drew Hasselback, "The billion-dollar judge: Class action lawsuits about more than frivolous claims"

Financial Post, online: < http://business.financialpost.com/legal-post/the-billion-dollar-judge-class-action-lawsuits-areabout-more-than-frivolous-claims>. In addition to Strathy J, Perrell J (see e.g. Spina v Shoppers Drug Mart Inc, 2012 ONSC 5563, [2012] OJ No 4659 (SCJ)), Conway J (see e.g. Clark (Litigation Gguardian of) v Ontario, 2014 ONSC 1283, 2014 CarswellOnt 2725 (SCJ)), Belobaba J (see e.g. Goldsmith v National Bank of Canada, 2015 ONSC 2746, 126 OR (3d) 191 (SCJ)), and Horkins J (see e.g. Sagharian (Litigation Guardian of) v Ontario (Minister of Education), 2012 ONSC 3478, 2012 CarswellOnt 8513 (SCJ)) have also served in this respect this decade.

197 Raji \#1, supra note 7 at para 9.

198 Julie Macfarlane, Katrina Trask \& Erin Chesney, “The Use of Summary Judgment Procedures Against Self-Represented Litigants: Efficient Case Management or Denial of Access to Justice?" (Windsor, ON: The National Self-Represented Litigants Project, The University of Windsor, Nov 2015) [Macfarlane, Trask \& Chesney, "Vexatiousness"]. 
successfully employed against self-represented litigants. This should create ethical pause before the Rule is employed. There is also good reason for believing that several individuals against whom Rule 2.1 is employed are mentally ill, presenting unique challenges to ensure their rights are respected. ${ }^{199}$

The Law Society of Ontario's Rules of Professional Conduct ${ }^{200}$ only prescribe basic standards regarding professional obligations. ${ }^{201}$ Nonetheless, while they are clearly not a sufficient basis upon which to form an ethical decision, they are still relevant and need to be considered. The LSO Rules prescribe particular duties when a party in litigation is self-represented. ${ }^{202}$ As one example, counsel have a duty not to conceal a binding authority even if not raised by other parties. ${ }^{203}$ Though this duty applies to counsel in all cases, it is likely to be especially germane when a self-represented litigant is on the other side. ${ }^{204}$ In summary procedures, it is particularly important that this rule not be ignored, ${ }^{205}$ as there is likely less opportunity for counsel and the judge to recognize the omission of an on-point authority. Firm admonishments and costs consequences in the face of improper uses of Rule 2.1, as have been seen to date, ${ }^{206}$ appear warranted.

But the real bulwarks against abuse of Rule 2.1 are judges - the individuals assigned to assess whether any particular potential use of the Rule is appropriate. The above cases illustrate that judges are cognizant of their obligation to grant more indulgences to self-represented litigants, particularly on procedural matters. ${ }^{207}$ However, Rule 2.1 does not provide for any "in court" time for a party to explain his or her case to a judge. This reduces the opportunities that a judge has to ensure that the rights of self-represented litigants are protected. ${ }^{208}$ This could illustrate public dispute resolution systems adopting many of the features of private dispute resolution, including a lesser amount of procedural protections. While at times this is desirable, in the name of efficiency and proportionality, it also creates risks, particularly for vulnerable parties. This could in fact illustrate that privatization of civil justice results in some of the

199 See e.g. Shafirovitch, supra note 81.

200 Law Society of Upper Canada, Rules of Professional Conduct, Toronto: LSUC, 2014 [LSO, "Rules"].

201 Adam Dodek \& Alice Woolley, "Introduction” in Dodek \& Woolley, supra note 14 at 5; Gerard J Kennedy, "Searching Through Storytelling: Book Review of In Search of the Ethical Lawyer: Stories from the Canadian Legal Profession" (2016) 33:1 Windsor YB Access Just 177.

202 LSO Rules, supra note 200, Rule 7.2-9 (Unrepresented persons) and the commentary to Rules 3.2-4 (Encouraging Compromise or Settlement) and 5.1-2 (Advocacy).

203 The contours of this duty, and its appropriateness in all circumstances, are controversial: Stephen GA Pitel \& Yu Seon Gadsden-Chung, "Reconsidering a Lawyer's Obligation to Raise Adverse Authority" (2016) 49:2 UBC L Rev 521.

204 See LSUC's “Dealing With Self-Represented Litigants," online: The Law Society of Upper Canada $<$ http://www.lsuc.on.ca/with.aspx?id=2147499412>.

205 Pitel \& Gadsden-Chung, supra note 203, suggest that this apply not only in cases of intentional misleading, but also when the omission occurred as a result of recklessness or carelessness.

206 Supra note 99.

207 Davids v Davids (1999), 125 OAC 375 (CA) at para 36.

208 See the discussion in Sanzone v Schechter, 2016 ONCA 566, 402 DLR (4th) 135 ["Sanzone"]. There is similar concern that the use of the technology in the courtroom could disadvantage marginalized populations: see, e.g., Suzanne Bouclin, Jena McGill \& Amy Salyzyn, "Mobile and Web-Based Legal Apps: Opportunities, Risks and Information Gaps" (April 28, 2017). Canadian Journal of Law and Technology, Fall 2017, Forthcoming; Ottawa Faculty of Law Working Paper No. 2017-17. Available at SSRN: <https://ssrn.com/abstract=2960207>. 
negative consequences Farrow describes arising even in the public justice system as courts feel obliged to "compete" with more efficient, private alternatives. ${ }^{209}$

Appellate courts have repeatedly held that the Rules must be interpreted flexibly to treat selfrepresented litigants fairly. For instance, in Sanzone $v$ Schechter, the Ontario Court of Appeal held that a motions judge held a self-represented litigant to an unrealistic standard of what constituted an expert report while responding to the defendants' summary judgment motion. ${ }^{210}$ In Wouters $v$ Wouters, the same court held that it was inappropriate to strike a self-represented litigant's pleadings after, among other things, the motion judge failed to turn his mind to whether any of the - admittedly improperly prepared - materials before him could have been of assistance. ${ }^{211}$ In Pintea $v$ Johns, Karakatsanis J ruled on behalf of a unanimous Supreme Court of Canada that a motion judge gave insufficient consideration to whether it was proven beyond a reasonable doubt that a self-represented litigant had actual knowledge of two orders she was held in contempt for violating. ${ }^{212}$ In Bernard $v$ Canada, Rothstein J cautioned against overly technical interpretations of court rulings that would prevent a self-represented litigant from raising an argument. $^{213}$

The National Self-Represented Litigants Project [NSRLP] has suggested that Rules 20 and 21 should be applied with particular restraint against self-represented litigants, noting that self-represented litigants frequently feel "ambushed" by summary procedures, and that judicial education and further monitoring of the outcomes of summary procedures may be appropriate. ${ }^{214}$ The NSRLP has also suggested that "vexatious" is a term disproportionately levelled against self-represented litigants. ${ }^{215}$

These concerns are real, and there would appear little downside to the NSRLP's encouragement of further judicial training to manage allegedly vexatious litigation. ${ }^{216}$ So why I am sanguine that these concerns can be mitigated in the context of Rule 2.1? Largely because Rule 2.1 addresses cases that are so egregious that there is every reason - theoretical and empirical - to believe that robustly enforced substantive and procedural doctrine will constrain the potential for abuse. Rule 2.1 is designed to address matters that are on their face destined to fail because they are manifestly abusive - a much higher standard than Rules 20 and 21. As Lorne Sossin has observed, even when procedural restraint is called for, "it should not permit frivolous and vexatious matters to tie up judicial resources." 217 Procedurally, unlike the NSRLP's concerns regarding Rules 20 and 21, the responding party is not permitted to bamboozle a selfrepresented litigant through lawyerly tactics because they are not allowed to make submissions at all. An

209 Farrow, "Book," supra note 109 at, e.g., 232-251.

210 Sanzone, supra note 208.

2112018 ONCA 26, 6 RFL (8th) 305 [Wouters] at paras 36-38. The impropriety was obvious but technical, exemplified in the failure to present evidence under oath.

2122017 SCC 23, [2017] 1 SCR 470 [“Pintea"].

2132014 SCC 13, [2014] 1 SCR 227 (partially dissenting, though the majority did not address this issue).

214 Macfarlane, Trask \& Chesney, "Vexatiousness," supra note 198.

215 Sandra Shushani, Lidia Imbrogno \& Julie Macfarlane, "Introducing the Self-Represented Litigant Database” (Windsor, ON: The National Self-Represented Litigants Project, the University of Windsor, Dec 2017) [Shushani, Imbrogno \& MacFarlane, "NRSLP Database"] at 7-9.

216 Macfarlane, Trask \& Chesney, "Vexatiousness," supra note 198; see also Macfarlane, "Main Report," supra note 144 at 125.

217 Gerard J Kennedy \& Lorne Sossin, "Justiciability, Access to Justice \& the Development of Constitutional Law in Canada" (2017) 45:4 Fed LR 707 at 713. 
extremely generous screening of each case is required, responding to the NSRLP's concerns that vexatiousness and lack of merit will be conflated. ${ }^{218}$ Adding further procedural protections would defeat the purpose of the Rule, which is to keep the responding party's costs to an absolute minimum. It is important to remember that Karakatsanis J, the author of the unanimous Pintea, was also author of the unanimous Hryniak, calling for broader use of summary procedures. And as explained above, having read all 190 reported cases using the Rule from its first three years, none where its use was ultimately upheld seemed to have tenable causes of action. Many of them originate from the same querulant individuals. It appears to be genuine vexatiousness - and not mere inability to properly fill out court forms ${ }^{219}$ - that leads to the use of Rule 2.1 .

There are, moreover, numerous examples of judges offering procedural assistance to parties before them in Rule 2.1 cases - Di Luca J in Van Sluytman v Orillia Soliders' Memorial Hospital is an eloquent example: "In reviewing this claim, I consider the fact that the Plaintiff is self-represented and of low income. I am not holding his statement of claim to the standard regularly expected with material prepared by counsel." 220 This is in line with the Court of Appeal's instruction in Wouters that the Rules "are not so rigid or inflexible as to preclude the court from examining non-compliant documents submitted by selfrepresented litigants to ensure that any properly admissible portions are received."221 As long as judges continue to recognize that even a hint of a tenable cause of action is a reason to decline to use Rule 2.1, the risk of abuse of minimal. Other instances of judges assisting self-represented litigants have included suggesting where to obtain legal advice, ${ }^{222}$ noting that the litigant has brought an appeal in the wrong court, ${ }^{223}$ and pointing to a resource on drafting pleadings. ${ }^{224}$ While this may pose some concerns that judges are no longer strictly neutral, ${ }^{225}$ it still appears the best way to achieve efficient access to justice, and respect the rights of self-represented litigants. ${ }^{226}$ So long as judges continue to fulfill their duties in

218 Shushani, Imbrogno \& MacFarlane, "NRSLP Database," supra note 215 at 9.

219 As noted in Wouters, supra note 211, these are very different phenomena. See also Ashley Haines, "When Dealing with a Self-Represented Litigant, Judges May Accept Non-Compliant Documents Where Appropriate" CanLII Connects (19 March 2018), online: <http://canliiconnects.org/en/commentaries/54989>.

220 Van Sluytman v Orillia Soldiers' Memorial Hospital, 2017 ONSC 692, [2017] OJ No 445 (SCJ) at para 12.

221 Wouters, supra note 211 at para 38.

222 Lee v Future Bakery Ltd, 2015 ONSC 3208, 2015 CarswellOnt 7464 (SCJ) at para 5.

223 Lin v Fluery, supra note 78.

224 Rallis, supra note 74 at para 5.

225 A concern famously flagged by Lord Denning in Jones v National Coal Board (1957), [1957] 2 ALL ER 155 (CA), citing Yuill v Yuill (1944), [1945] 1 All ER 183 (CA); Freya Kristjanson (as she then was) and Sharon Naipul also explored this in Kristjanson \& Naipul, supra note 155.

226 Kristjanson \& Naipul, ibid at 221-222, explore the tests imposed by appellate courts with respect to limits in this regard. The test for reasonable apprehension of bias remains the final bulwark against a judge who assumes the role of advocate: Committee for Justice and Liberty et al v National Energy Board et al, [1978] 1 SCR 369 at 394 (per de Grandpré J, dissenting but widely cited since then for the test for reasonable apprehension of bias: see e.g. Stuart Budd \& Sons Limited v IFS Vehicle Distributors ULC, 2016 ONCA 60, 129 OR (3d) 37). The theoretical difficulties with the adversarial system of litigation as a mechanism to achieve access to justice - and whether such a system even exists - is a very interesting topic (see e.g. Sasha Lallouz, "A Call for Ethical Accountability: The Necessity for Lawyer-Client Ethical Dialogue in a One-Sided Adversarial System" (2016) Windsor Rev Legal \& Soc Issues 37), albeit one far beyond the scope of this article. 
this regard, there is every reason to believe that concerns with denying vulnerable parties a hearing in the face of truly vexatious matters will be mitigated.

The need for judges to offer assistance to parties - and read pleadings extremely generously - is heightened when there is a concern that a party is suffering from mental illness. In this vein, giving extensions of time ${ }^{227}$ or asking clarifications about the nature of a party's allegations may be appropriate. Such correspondence would not technically be ex parte, as responding parties would be copied, but would presumably involve minimal expense for responding parties, thus according with the spirit of Rule 2.1.

Having said that, frivolous claims remain frivolous claims. If an individual is suffering from a mental illness, the response must be compassionate and may have to be societal. But the courts are unlikely to be the appropriate forum for such a response. As noted above, in one case Myers J referred the plaintiff to the Public Guardian and Trustee ${ }^{228}$ - this is not something that judges should hesitate to do. Ultimately, this case recognizes that treating a mentally ill litigant with compassion can still be accompanied by the use of Rule 2.1. In many cases it seems essential to remove a person who needs help from a forum - the courts - incapable of providing that help. ${ }^{229}$

Finally, it is also worth remembering that demanding procedural protections of a nature such that there is literally no potential of an unjust result would likely be so costly as to defeat the goal of summary procedures. ${ }^{230}$ Lest there be any confusion, as I have emphasized throughout this article, not using Rule 2.1 is the side on which judges should err. This is both because the need to ensure just outcomes should not be compromised ${ }^{231}$ and because justice must generally trump efficiency if they are in a zero-sum conflict. ${ }^{232}$ Moreover, there are enough summary alternatives to Rule 2.1 that electing to not use Rule 2.1 in a marginal case is likely to have costs for a defendant that are small when compared to the interest of preserving not only justice, but its appearance. However, the desire to pursue a substantively fair outcome, without consideration of the costs, can be taken to an unhealthy extreme. ${ }^{233}$

227 Seen in, e.g., Goralczyk v The Beer Store, 2016 ONSC 1699, [2016] OJ No 1196 at para 5.

228 Shafirovitch, supra note 81 at para 5.

229 The institutional difficulty of the courts to address and assess mental illness is noted (admittedly in another context) in Hugh Harradence, "Re-Applying the Standard of Fitness to Stand Trial" (2013) 59 CLQ 511 at 537, summarizing Richard D Schneider, Hy Bloom \& Mark Herrema, Mental Health Courts Decriminalizing the Mentally Ill (Toronto: Irwin Law, 2007), including quoting p 145.

230 As Karakatsanis J noted in Hryniak, supra note 6 at para 29: "There is, of course, always some tension between accessibility and the truth-seeking function but, much as one would not expect a jury trial over a contested parking ticket, the procedures used to adjudicate civil disputes must fit the nature of the claim. If the process is disproportionate to the nature of the dispute and the interests involved, then it will not achieve a fair and just result."

231 Hryniak, ibid at para 23.

232 Farrow, "Book," supra note 109 at 271.

233 As an example, the experience of expanded discovery rights is frequently cited as an example of a change to procedural law to minimize substantive injustices that has seemingly had minimal effects in doing so while also greatly increasing costs. Justice Thomas Cromwell noted as much in extrajudicial comments in 2013 while still serving on the Supreme Court: Beverley Spencer, "The Road to Justice Reform: An Interview with Supreme Court of Canada Justice Thomas Cromwell” The National (July-Aug 2013), online: National Magazine <http://nationalmagazine.ca/Articles/Recent4/Theroad-to-justice-reform.aspx $>$. This is also a common hypothesis in the United States: see e.g. Judge (as he then was) Neil Gorsuch, "13th Annual Barbara K. Olson Memorial Lecture" (Address Delivered at the Federalist Society for Law and Public Policy's 2013 National Lawyers Convention, The Mayflower Hotel, Washington, DC, 15 Nov 2013), online: $<$ https://www.youtube.com/watch?v=VI_c-5S4S6Y> at 6:15-10:30. See also Hryniak, supra note 6 at para 29. 


\section{CONCLUSION}

In 2017, one Ontario judge made headlines when he criticized - in mocking tone - parties for coming before him to deal with a matter he considered frivolous and manifestly a waste of the Court's resources. ${ }^{234}$ But after a few days of mostly gleeful media praise, ${ }^{235}$ Alice Woolley (prior to her appointment to the bench) wrote a thoughtful article in which she noted that the parties had a legitimate grievance, and regardless of how efficient the judge thought his solution was, it could never have been upheld by an appellate court as it was based on contradictory suppositions. ${ }^{236}$ This instance therefore recognizes the dangers of judges using their powers, including their powers to summarily dismiss matters, inappropriately. And as damaging as vexatious litigation can be from the perspective of the court system, well-resourced defendants can at times claim "abusive" when litigation is anything but - demonstrating the danger that the term, like "civility," could be used to attempt to silence those who seek to disrupt the status quo. ${ }^{237}$ Occasionally, judges even fall into the trap of emphasizing efficiency over justice. This trap must be strenuously avoided, particularly when there is a self-represented litigant or a concern that a person suffering from mental illness is affected.

Simultaneously, litigation that is vexatious can cause significant problems. When a poorly resourced, potentially self-represented party comes before the Court, judges should be inclined to grant the party more indulgences. ${ }^{238}$ However, the fact that a party is on the margins of society does not mean that he or she has a legitimate legal grievance. The disproportionate damage that vexatious litigation can do to the civil justice system, as well as societal perceptions of it, ${ }^{239}$ is undeniable. Though such litigation is far from the norm, the above analysis explains how there are still dozens of reported examples of it in Ontario alone every year. Inflicting the costs of this upon innocent parties - even well-resourced innocent parties - is manifestly unjust.

In light of these concerns, Rule 2.1 sought to balance the interests of the court system, plaintiffs, and defendants. And, despite minor hiccoughs, it appears to have succeeded. Civil procedure reform is hardly a catch-all solution for ensuring access to justice, but it can surely play a role. Rule 2.1 has allowed judges to address truly frivolous, vexatious, and/or abusive motions and actions in a way that is fair to the affected parties, recognizing that what constitutes a fair hearing varies according to the circumstances. Other jurisdictions should take note if they have not already done so. ${ }^{240}$ There are risks created by the Rule -

234 Abdulaali v Salih, 2017 ONSC 1609, 92 RFL (7th) 355 (SCJ).

235 See e.g. Christie Blatchford, "Getting to the root of Ontario's family law mess" National Post (21 March 2017), online:

$<$ http://nationalpost.com/opinion/christie-blatchford-getting-to-the-root-of-ontarios-family-law-mess $>$.

236 “Judgmental Judges," Slaw (22 March 2017); online: <http://www.slaw.ca/2017/03/22/judgmental-judges/>.

See e.g. Constance Backhouse, "Gender and Race in the Construction of 'Legal Professionalism': Historical

Perspectives" in Dodek \& Woolley, supra note 14 at 128.

238 Supra, Part IV.A.6.

239 Mathieu \& McLean, supra note 150.

240 Some jurisdictions already have such rules, such as Prince Edward Island (Rule 2.1 of the Prince Edward Island Rules of Civil Procedure, based on the fact that PEI largely uses the same Rules as Ontario: see Doyle v Roberts \& PEI Mutual, 2015 PEISC 2, 361 Nfld \& PEIR 127, explaining the link with Ontario, and Taha v Government of PEI, 2018 PEICA 18, 2018 CarswellPEI 56, explaining the integration of Rule 2.1) and Alberta: Court of Queen's Bench, Civil Practice Court: Note 7, online: Alberta Courts $<$ https://albertacourts.ca/docs/default-source/qb/civil-practice-note-7---vexatiousapplication-proceeding-show-cause-procedure.pdf?sfvrsn=cb2fa480 4>, effective Sept 4, 2018. Manitoba and 
and potential ways to make its application more streamlined - but these are minimal and/or can be managed. Access to justice has been improved in narrow but very real circumstances. A simple amendment to the Rules - which are not merely regulatory but can also have valuable hortatory effects has achieved this. ${ }^{241}$ That is worth celebrating.

\section{APPENDIX A - METHODOLOGY}

I attempted to find all reported cases using Rule 2.1 from its coming into force on July 1, 2014 through June 30, 2017. I have done this through searching QuickLaw and Westlaw throughout 2017. There are limitations of such an approach. Notably, though QuickLaw and Westlaw report most decided reported cases in Ontario, they do not necessarily report every single case. ${ }^{242}$ Nonetheless, quantitative analyses of case law frequently proceed from their use. ${ }^{243}$ Moreover, given the summary nature of Rule 2.1 , there is good reason to suspect many decisions that use it are not reported. There are also inherent limitations to a quantitative analysis of case law - notably, it is difficult to draw normative lessons from such an analysis. ${ }^{244}$ However, I address the normative values implicated by Rule 2.1 in Parts II, III, and particularly IV, of this article.

While reviewing these cases, I kept track of the following facts:

- What cases have emerged as "leading" to provide guidance to members of the bar and bench on how to apply the Rule.

- How many cases were being resolved pursuant to the Rule and how many attempts to use the Rule are successful: I analyzed whether the Rule is enabling the prompt resolution of claims on their merits, which would be the case if there are a large number of successful uses, and a minimal number of unsuccessful uses.

- The rates of appeals and successful appeals, which suggest something about the clarity of the Rule's meaning and/or whether the judges are misapplying it (accepting that an appellate court overruling a lower court is not necessarily an indictment of the lower court decision $^{245}$ ).

- Any costs orders involved, as costs orders shed light on financial expense, and are thus relevant to assessing whether the Rule is having a positive effect on access to justice

Saskatchewan also allow a judge to waive the Court of Queen's Bench Rules (potentially sua sponte) in response to vexatious actions: Court of Queen's Bench Rules, Man Reg 553/88, Rule 2.04; The Queen's Bench Rules, Rule 5-3. These are nonetheless distinguishable (e.g. Alberta's procedure gives a different timeframe for response). 991 at 1013.

242 Brown v Lloyds of London Insurance Market, 2015 ONCA 235, [2015] OJ No 1739 is an appeal of an unreported trial decision.

243 See e.g. Craig E Jones \& Micah B Rankin, "Justice as a Rounding Error? Evidence of Subconscious Bias in SecondDegree Murder Sentences in Canada" (2014) 52 Osgoode Hall LJ 109 at 121, fn 58; Kennedy, supra note 114.

244 See e.g. Joshua B Fischman, "Reuniting 'Ought' and 'Is' in Empirical Legal Scholarship" (2013) 162:1 U Pa L Rev 117; Kennedy, ibid.

245 Fischman, ibid at 142. 
(recognizing that costs awards typically reflect only about half of actual costs incurred $^{246}$ ).

- How long Rule 2.1 is delaying the resolution of actions: in the case of successful uses of the Rule, it is evidence of how promptly cases are being resolved on their merits. In the case of unsuccessful uses, I can assess whether the Rule is in fact a hindrance to access to justice, as this must be weighed against the Rule's ability to help achieve access to justice in other cases.

- The identity of the judge deciding the motion and whether this affects the aforementioned "access to justice"-related variables. This is particularly important to analyze given that Justice Fred Myers has decided a disproportionate number of cases, having been appointed by the Toronto Team Leader-Civil to address the Rule. ${ }^{247}$ Justices Robert Beaudoin of the Superior Court in Ottawa and Ian Nordheimer sitting on the Divisional Court in Toronto (prior to his elevation to the Court of Appeal) have also decided a disproportionate number of cases using Rule 2.1.

- Whether the case was prompted by a judge's own initiative, or referred to the judge by a responding party or the registrar, to discover who is employing the Rule.

- The reason why the proceeding was alleged to be vexatious. I include very short descriptions of all in Appendix B, though I highlight certain prominent types of cases in Parts IIC2 and IIC5.

- Whether the party against whom Rule 2.1 was sought to be employed was a selfrepresented litigant.

All of these details are recorded in Appendix B.

\section{APPENDIX B - ALL CASES BY DATE}

\begin{tabular}{|c|c|c|c|c|c|c|c|c|c|c|c|c|c|}
\hline & $\begin{array}{l}\text { Case } \\
\text { Name }\end{array}$ & $\begin{array}{l}\text { Resolu } \\
\text { tion } \\
\text { Date }\end{array}$ & Court & Source & $\begin{array}{l}\text { Notice } \\
\text { Ordered? }\end{array}$ & Decision & Result & Appeal & Costs & $\begin{array}{l}\text { Delay: } \\
\text { Notice to } \\
\text { Final } \\
\text { Dispositi } \\
\text { on }\end{array}$ & Judge(s) & Claim Type & $\begin{array}{l}\text { Self- } \\
\text { Rep? }\end{array}$ \\
\hline 1 & $\begin{array}{l}\text { Gao v } \\
\text { Ontario } \\
\text { (Workpla } \\
\text { ce Safety } \\
\text { and } \\
\text { Insurance } \\
\text { Board) }\end{array}$ & $\begin{array}{l}07- \\
\text { Nov- } \\
14\end{array}$ & SCJ & $\begin{array}{l}\text { Respond } \\
\text { ing Party }\end{array}$ & $\begin{array}{l}2014 \\
\text { ONSC } \\
6100,37 \\
\text { CLR (4th) } \\
1\end{array}$ & $\begin{array}{l}2014 \\
\text { ONSC } \\
6497,31 \\
\text { CPC } \\
\text { (7th) } 153\end{array}$ & $\begin{array}{l}\text { Granted } \\
\text { After } \\
\text { Notice }\end{array}$ & N/A & None & $\begin{array}{l}18 \text { Days: } \\
\text { Oct } 20 \text {, } \\
2014 \text { to } \\
\text { Nov } 7 \\
2014\end{array}$ & Myers & $\begin{array}{l}\text { Motion in } \\
\text { dismissed } \\
\text { claim }\end{array}$ & $\begin{array}{l}\text { Uncl } \\
\text { ear }\end{array}$ \\
\hline 2 & $\begin{array}{l}\text { Markowa } \\
v \\
\text { Adamson } \\
\text { Cosmetic } \\
\text { Facial } \\
\text { Surgery } \\
\text { Inc }\end{array}$ & $\begin{array}{l}14- \\
\text { Nov- } \\
14\end{array}$ & SCJ & Unclear & N/A & $\begin{array}{l}2014 \\
\text { ONSC } \\
6664, \\
{[2014]} \\
\text { OJ No } \\
5430\end{array}$ & $\begin{array}{l}\text { Granted } \\
\text { After } \\
\text { Notice }\end{array}$ & N/A & Unclear & $\begin{array}{l}25 \text { Days: } \\
\text { Oct } 20 \text {, } \\
2014 \text { to } \\
\text { Nov } 14 \text {, } \\
2014\end{array}$ & Myers & $\begin{array}{l}\text { Attempt to } \\
\text { re-litigate }\end{array}$ & Yes \\
\hline
\end{tabular}

\footnotetext{
246 See e.g. Horne, supra note 136 at 61.
}

247 Goralczyk \#1, supra note 134 at para 6. 


\begin{tabular}{|c|c|c|c|c|c|c|c|c|c|c|c|c|c|}
\hline 3 & Ali v Ford & $\begin{array}{l}14- \\
\text { Nov- } \\
14\end{array}$ & SCJ & Unclear & N/A & $\begin{array}{l}2014 \\
\text { ONSC } \\
6665, \\
{[2014]} \\
\text { OJ No } \\
5426\end{array}$ & $\begin{array}{l}\text { Granted } \\
\text { After } \\
\text { Notice }\end{array}$ & N/A & Unclear & $\begin{array}{l}25 \text { Days: } \\
\text { Oct } 20 \text {, } \\
2014 \text { to } \\
\text { Nov } 14 \text {, } \\
2014\end{array}$ & Myers & OPCA & Yes \\
\hline 4 & $\begin{array}{l}\text { Crawford } \\
v \text { Carey }\end{array}$ & $\begin{array}{l}05- \\
\text { Dec- } \\
14\end{array}$ & SCJ & Unclear & N/A & $\begin{array}{l}2014 \\
\text { ONSC } \\
7054, \\
{[2014]} \\
\text { OJ No } \\
5824\end{array}$ & $\begin{array}{l}\text { Dismisse } \\
\text { d After } \\
\text { Notice }\end{array}$ & N/A & Unclear & $\begin{array}{l}28 \text { Days: } \\
\text { Nov } 7 \text {, } \\
2014 \text { to } \\
\text { Dec } 5 \text {, } \\
2014\end{array}$ & Myers & $\begin{array}{l}\text { Tortious acts } \\
\text { of building } \\
\text { owner and } \\
\text { developer }\end{array}$ & $\begin{array}{l}\text { Uncl } \\
\text { ear }\end{array}$ \\
\hline 5 & $\begin{array}{l}\text { Nolan v } \\
\text { Law } \\
\text { Society of } \\
\text { Upper } \\
\text { Canada }\end{array}$ & $\begin{array}{l}11- \\
\text { Dec- } \\
14\end{array}$ & SCJ & Unclear & N/A & $\begin{array}{l}2014 \\
\text { ONSC } \\
7196, \\
{[2014]} \\
\text { OJ No } \\
5989\end{array}$ & $\begin{array}{l}\text { Granted } \\
\text { After } \\
\text { Notice }\end{array}$ & N/A & Unclear & $\begin{array}{l}\text { 52 Days: } \\
\text { Oct 20, } \\
2014 \text { to } \\
\text { Dec } 11, \\
2014 \\
\text { (Plaintiff } \\
\text { could not } \\
\text { be } \\
\text { reached) }\end{array}$ & Myers & $\begin{array}{l}\text { Forced } \\
\text { resignation } \\
\text { from LSUC } \\
\text { in } 1986\end{array}$ & $\begin{array}{l}\text { Uncl } \\
\text { ear }\end{array}$ \\
\hline 6 & $\begin{array}{l}\text { Brown v } \\
\text { Lloyds of } \\
\text { London } \\
\text { Insurance } \\
\text { Market }\end{array}$ & $\begin{array}{l}05- \\
\text { Jan-15 }\end{array}$ & SCJ & Unclear & N/A & N/A & $\begin{array}{l}\text { Granted } \\
\text { After } \\
\text { Notice }\end{array}$ & $\begin{array}{l}\text { Affirme } \\
\text { d: } 2015 \\
\text { ONCA } \\
235, \\
{[2015]} \\
\text { OJ No } \\
1739\end{array}$ & None & $\begin{array}{l}\text { Unclear/ } \\
\text { About } \\
120 \\
\text { Days: } \\
\text { Unclear } \\
\text { to Dec } \\
2014 \text { to } \\
\text { April 9, } \\
2015 \\
\text { (appeal) }\end{array}$ & Myers & $\begin{array}{l}\text { Not } \\
\text { discernible; } \\
\text { no cause of } \\
\text { action }\end{array}$ & Yes \\
\hline 7 & $\begin{array}{l}\text { Hawkins } \\
v \\
\text { Schlosser }\end{array}$ & $\begin{array}{l}28- \\
\text { Jan-15 }\end{array}$ & SCJ & Unclear & N/A & $\begin{array}{l}2015 \\
\text { ONSC } \\
646, \\
{[2015]} \\
\text { OJ No } \\
372\end{array}$ & $\begin{array}{l}\text { Granted } \\
\text { After } \\
\text { Notice }\end{array}$ & N/A & $\begin{array}{l}\$ 1,148 . \\
02: \\
2015 \\
\text { ONSC } \\
1691, \\
{[2015]} \\
\text { OJ No } \\
1346\end{array}$ & $\begin{array}{l}13 \text { Days: } \\
\text { Jan } 15 \text {, } \\
2015 \text { to } \\
\text { Jan } 28 \text {, } \\
2015\end{array}$ & Ellies & $\begin{array}{l}\text { Procedurally } \\
\text { flawed family } \\
\text { proceeding }\end{array}$ & $\begin{array}{l}\text { Uncl } \\
\text { ear }\end{array}$ \\
\hline 8 & $\begin{array}{l}\text { Stefanizzi } \\
v \text { Ontario } \\
\text { (Landlord } \\
\text { and } \\
\text { Tenant } \\
\text { Board) }\end{array}$ & $\begin{array}{l}05- \\
\text { Feb- } \\
15\end{array}$ & SCJ & Registrar & N/A & $\begin{array}{l}2015 \\
\text { ONSC } \\
859, \\
{[2015]} \\
\text { OJ No } \\
562\end{array}$ & $\begin{array}{l}\text { Granted } \\
\text { After } \\
\text { Notice }\end{array}$ & N/A & Unclear & $\begin{array}{l}\text { 11 Days: } \\
\text { Jan 25, } \\
2015 \text { to } \\
\text { Feb 5, } \\
2015\end{array}$ & Kurke & $\begin{array}{l}\text { Attempt to } \\
\text { re-litigate }\end{array}$ & $\begin{array}{l}\text { Uncl } \\
\text { ear }\end{array}$ \\
\hline 9 & $\begin{array}{l}\text { Williams } \\
v \text { Law } \\
\text { Society of } \\
\text { Upper } \\
\text { Canada }\end{array}$ & $\begin{array}{l}09- \\
\text { Feb- } \\
15\end{array}$ & SCJ & $\begin{array}{l}\text { Respond } \\
\text { ing Party }\end{array}$ & $\begin{array}{l}2015 \\
\text { ONSC } \\
913, \\
{[2015] \text { OJ }} \\
\text { No } 619\end{array}$ & N/A & $\begin{array}{l}\text { Notice } \\
\text { Ordered; } \\
\text { Unclear } \\
\text { Result }\end{array}$ & N/A & Unclear & N/A & Myers & $\begin{array}{l}\text { Mental } \\
\text { distress due } \\
\text { to poor } \\
\text { LSUC } \\
\text { regulation }\end{array}$ & $\begin{array}{l}\text { Uncl } \\
\text { ear }\end{array}$ \\
\hline 10 & $\begin{array}{l}\text { Parkv } \\
\text { Short }\end{array}$ & $\begin{array}{l}26- \\
\text { Feb- } \\
15\end{array}$ & SCJ & $\begin{array}{l}\text { Respond } \\
\text { ing Party }\end{array}$ & $\mathrm{N} / \mathrm{A}$ & $\begin{array}{l}2015 \\
\text { ONSC } \\
1292, \\
{[2015]} \\
\text { OJ No } \\
926\end{array}$ & $\begin{array}{l}\text { Granted } \\
\text { Without } \\
\text { Notice }\end{array}$ & N/A & Unclear & 0 Days & Myers & $\begin{array}{l}\text { Commenced } \\
\text { in violation } \\
\text { of vexatious } \\
\text { litigant order }\end{array}$ & Yes \\
\hline
\end{tabular}




\begin{tabular}{|c|c|c|c|c|c|c|c|c|c|c|c|c|c|}
\hline 11 & $\begin{array}{l}\text { Rousay v } \\
\text { Rousay }\end{array}$ & $\begin{array}{l}27- \\
\text { Feb- } \\
15\end{array}$ & SCJ & $\begin{array}{l}\text { Respond } \\
\text { ing Party }\end{array}$ & N/A & $\begin{array}{l}2015 \\
\text { ONSC } \\
1336 \\
{[2015]} \\
\text { OJ No } \\
930\end{array}$ & $\begin{array}{l}\text { Granted } \\
\text { After } \\
\text { Notice }\end{array}$ & N/A & Unclear & $\begin{array}{l}66 \text { Days: } \\
\text { Dec 23, } \\
2014 \text { to } \\
\text { Feb } 27 \\
2015\end{array}$ & $\begin{array}{l}\text { McEwe } \\
\mathrm{n}\end{array}$ & $\begin{array}{l}\text { Attempt to } \\
\text { re-litigate; } \\
\text { not } \\
\text { discernible }\end{array}$ & Yes \\
\hline 12 & $\begin{array}{l}\text { Raji v } \\
\text { Borden } \\
\text { Ladner } \\
\text { and } \\
\text { Gervais } \\
\text { LLP }\end{array}$ & $\begin{array}{l}02- \\
\text { Mar- } \\
15\end{array}$ & SCJ & $\begin{array}{l}\text { Respond } \\
\text { ing Party }\end{array}$ & $\begin{array}{l}2015 \\
\text { ONSC } \\
801, \\
{[2015] \text { OJ }} \\
\text { No } 307\end{array}$ & $\begin{array}{l}2015 \\
\text { ONSC } \\
2915 \\
{[2015]} \\
\text { OJ No } \\
976\end{array}$ & $\begin{array}{l}\text { Granted } \\
\text { After } \\
\text { Notice }\end{array}$ & $\mathrm{N} / \mathrm{A}$ & Unclear & $\begin{array}{l}\text { 35 Days: } \\
\text { Jan 26, } \\
2015 \text { to } \\
\text { March 2, } \\
2015\end{array}$ & Myers & $\begin{array}{l}\text { Attempt to } \\
\text { re-litigate }\end{array}$ & $\begin{array}{l}\text { Uncl } \\
\text { ear }\end{array}$ \\
\hline 13 & $\begin{array}{l}\text { Chowdhu } \\
\text { ryv } \\
\text { Banglade } \\
\text { shi- } \\
\text { Canadian } \\
\text { Communi } \\
\text { ty } \\
\text { Services } \\
\end{array}$ & $\begin{array}{l}06- \\
\text { Mar- } \\
15\end{array}$ & SCJ & $\begin{array}{l}\text { Respond } \\
\text { ing Party }\end{array}$ & $\begin{array}{l}2015 \\
\text { ONSC } \\
1534, \\
{[2015] \text { OJ }} \\
\text { No } 1081\end{array}$ & $\mathrm{~N} / \mathrm{A}$ & $\begin{array}{l}\text { Notice } \\
\text { Not } \\
\text { Ordered }\end{array}$ & $\mathrm{N} / \mathrm{A}$ & Unclear & $\mathrm{N} / \mathrm{A}$ & Myers & $\begin{array}{l}\text { Argument } \\
\text { Plaintiff's } \\
\text { Motion } \\
\text { Premature }\end{array}$ & $\begin{array}{l}\text { Uncl } \\
\text { ear }\end{array}$ \\
\hline 14 & $\begin{array}{l}\text { Beatty v } \\
\text { Ontario } \\
\text { (Attorney } \\
\text { General) }\end{array}$ & $\begin{array}{l}06- \\
\text { Mar- } \\
15\end{array}$ & SCJ & Unclear & N/A & $\begin{array}{l}2015 \\
\text { ONSC } \\
1519 \\
{[2015]} \\
\text { OJ No } \\
1290\end{array}$ & $\begin{array}{l}\text { Granted } \\
\text { After } \\
\text { Notice }\end{array}$ & $\mathrm{N} / \mathrm{A}$ & None & $\begin{array}{l}28 \text { Days: } \\
\text { Feb 6, } \\
2015 \text { to } \\
\text { March 6, } \\
2015\end{array}$ & Gray & $\begin{array}{l}\text { Attempt to } \\
\text { force } \\
\text { province to } \\
\text { alter policies } \\
\text { in absence of } \\
\text { factual basis }\end{array}$ & Yes \\
\hline 15 & $\begin{array}{l}\text { Lin } v \\
\text { Greither }\end{array}$ & $\begin{array}{l}09- \\
\text { Mar- } \\
15\end{array}$ & SCJ & Unclear & N/A & $\begin{array}{l}2015 \\
\text { ONSC } \\
1541 \\
{[2015]} \\
\text { OJ No } \\
1086\end{array}$ & $\begin{array}{l}\text { Granted } \\
\text { After } \\
\text { Notice }\end{array}$ & N/A & Unclear & $\begin{array}{l}\text { 19 days: } \\
\text { Feb 18, } \\
2015 \text { to } \\
\text { March 9, } \\
2015\end{array}$ & Myers & $\begin{array}{l}\text { Wrongful } \\
\text { dismissal in } \\
2009 \text { in } \\
\text { Vancouver; } \\
\text { complaints } \\
\text { against court } \\
\text { for } \\
\text { judgments; } \\
\text { complaints } \\
\text { against police } \\
\text { for failing to } \\
\text { investigate } \\
\text { crime }\end{array}$ & Yes \\
\hline 16 & $\begin{array}{l}\text { Gledhillv } \\
\text { Toronto } \\
\text { (City) } \\
\text { Police } \\
\text { Services } \\
\text { Board }\end{array}$ & $\begin{array}{l}18- \\
\text { Mar- } \\
15\end{array}$ & SCJ & $\begin{array}{l}\text { Respond } \\
\text { ing Party }\end{array}$ & $\begin{array}{l}2015 \\
\text { ONSC } \\
1006, \\
{[2015] \text { OJ }} \\
\text { No 733 } \\
\text { (second } \\
\text { notice) }\end{array}$ & $\begin{array}{l}2015 \\
\text { ONSC } \\
1755 \\
{[2015]} \\
\text { OJ No } \\
1297\end{array}$ & $\begin{array}{l}\text { Granted } \\
\text { After } \\
\text { Notice }\end{array}$ & $\mathrm{N} / \mathrm{A}$ & Unclear & $\begin{array}{l}33 \text { Days: } \\
\text { Feb 13, } \\
2015 \text { to } \\
\text { March } \\
18,2015\end{array}$ & Myers & $\begin{array}{l}\text { Not } \\
\text { discernible } \\
\text { and attempt } \\
\text { to re-litigate }\end{array}$ & Yes \\
\hline 17 & $\begin{array}{l}\text { Clarke v } \\
\text { Canada } \\
\text { (Human } \\
\text { Rights } \\
\text { Commissi } \\
\text { on) }\end{array}$ & $\begin{array}{l}18- \\
\text { Mar- } \\
15\end{array}$ & SCJ & Unclear & $\begin{array}{l}2015 \\
\text { ONSC } \\
1789, \\
{[2015] \text { OJ }} \\
\text { No } 1341\end{array}$ & $\begin{array}{l}2015 \\
\text { ONSC } \\
2564, \\
2015 \\
\text { Carswell } \\
\text { Ont 5611 }\end{array}$ & $\begin{array}{l}\text { Claim } \\
\text { Withdra } \\
\text { wn } \\
\text { Against } \\
1 \\
\text { Defenda } \\
\text { nt on } \\
\text { Consent }\end{array}$ & $\mathrm{N} / \mathrm{A}$ & None & $\begin{array}{l}\text { 27 Days: } \\
\text { Feb 19, } \\
2015 \text { to } \\
\text { March } \\
18,2015\end{array}$ & Myers & $\begin{array}{l}\text { Medical } \\
\text { malpractice } \\
\text { claim against } \\
\text { improper } \\
\text { defendant }\end{array}$ & Yes \\
\hline 18 & $\begin{array}{l}\text { Husain v } \\
\text { Craig }\end{array}$ & $\begin{array}{l}18- \\
\text { Mar- } \\
15\end{array}$ & SCJ & $\begin{array}{l}\text { Respond } \\
\text { ing Party }\end{array}$ & $\begin{array}{l}2015 \\
\text { ONSC } \\
1754, \\
{[2015] \text { OJ }} \\
\text { No } 1300\end{array}$ & $\mathrm{~N} / \mathrm{A}$ & $\begin{array}{l}\text { Notice } \\
\text { Not } \\
\text { Ordered }\end{array}$ & $\mathrm{N} / \mathrm{A}$ & Unclear & $\mathrm{N} / \mathrm{A}$ & Myers & $\begin{array}{l}\text { Claim } \\
\text { Against } \\
\text { Criminal } \\
\text { Defence } \\
\text { Lawyer }\end{array}$ & Yes \\
\hline
\end{tabular}




\begin{tabular}{|c|c|c|c|c|c|c|c|c|c|c|c|c|c|}
\hline 19 & $\begin{array}{l}\text { Di Marco } \\
\text { v Lattuca }\end{array}$ & $\begin{array}{l}10- \\
\text { Apr- } \\
15\end{array}$ & SCJ & Unclear & N/A & $\begin{array}{l}2015 \\
\text { ONSC } \\
2341, \\
{[2015]} \\
\text { OJ No } \\
1845\end{array}$ & $\begin{array}{l}\text { Granted } \\
\text { After } \\
\text { Notice }\end{array}$ & N/A & Unclear & $\begin{array}{l}50 \text { Days: } \\
\text { Feb 19, } \\
2015 \text { to } \\
\text { April 10, } \\
2015\end{array}$ & Myers & $\begin{array}{l}\text { Attempt to } \\
\text { re-litigate }\end{array}$ & $\begin{array}{l}\text { Uncl } \\
\text { ear }\end{array}$ \\
\hline 20 & $\begin{array}{l}\text { Lin v } \\
\text { Rock }\end{array}$ & $\begin{array}{l}14- \\
\text { Apr- } \\
15\end{array}$ & SCJ & $\begin{array}{l}\text { Respond } \\
\text { ing Party }\end{array}$ & N/A & $\begin{array}{l}2015 \\
\text { ONSC } \\
2421, \\
{[2015]} \\
\text { OJ No } \\
1851\end{array}$ & $\begin{array}{l}\text { Granted } \\
\text { Without } \\
\text { Notice }\end{array}$ & $\mathrm{N} / \mathrm{A}$ & None & N/A & Myers & $\begin{array}{l}\text { Motion } \\
\text { brought } \\
\text { before wrong } \\
\text { decision- } \\
\text { maker }\end{array}$ & Yes \\
\hline 21 & $\begin{array}{l}\text { Gledhill v } \\
\text { Toronto } \\
\text { (City) } \\
\text { Police } \\
\text { Services } \\
\text { Board }\end{array}$ & $\begin{array}{l}14- \\
\text { Apr- } \\
15\end{array}$ & SCJ & Unclear & $\begin{array}{l}2015 \\
\text { ONSC } \\
2068, \\
2015 \\
\text { Carswell } \\
\text { Ont 5323 }\end{array}$ & $\begin{array}{l}2015 \\
\text { ONSC } \\
2418, \\
{[2015]} \\
\text { OJ No } \\
1847\end{array}$ & $\begin{array}{l}\text { Granted } \\
\text { After } \\
\text { Notice }\end{array}$ & $\mathrm{N} / \mathrm{A}$ & Unclear & $\begin{array}{l}\text { 15 Days: } \\
\text { March } \\
30,2015 \\
\text { to April } \\
14,2015\end{array}$ & Myers & $\begin{array}{l}\text { Attempt to } \\
\text { re-litigate }\end{array}$ & Yes \\
\hline 22 & $\begin{array}{l}\text { Covenoho } \\
v \\
\text { Ceridian } \\
\text { Canada }\end{array}$ & $\begin{array}{l}16- \\
\text { Apr- } \\
15\end{array}$ & SCJ & $\begin{array}{l}\text { Respond } \\
\text { ing Party }\end{array}$ & $\begin{array}{l}2015 \\
\text { ONSC } \\
2468, \\
{[2015] \text { OJ }} \\
\text { No } 1889\end{array}$ & N/A & $\begin{array}{l}\text { Notice } \\
\text { Not } \\
\text { Ordered }\end{array}$ & N/A & Unclear & N/A & Myers & $\begin{array}{l}\text { Defendants } \\
\text { attempt to } \\
\text { raise merits } \\
\text { in } 6 \text { page } \\
\text { submissions }\end{array}$ & Yes \\
\hline 23 & $\begin{array}{l}\text { Cao v } \\
\text { Whirlpool } \\
\text { Corp }\end{array}$ & $\begin{array}{l}20- \\
\text { Apr- } \\
15\end{array}$ & SCJ & $\begin{array}{l}\text { Respond } \\
\text { ing Party }\end{array}$ & $\begin{array}{l}2015 \\
\text { ONSC } \\
1266, \\
{[2015] \text { OJ }} \\
\text { No } 884\end{array}$ & $\begin{array}{l}2015 \\
\text { ONSC } \\
2582, \\
{[2015]} \\
\text { OJ No } \\
1990\end{array}$ & $\begin{array}{l}\text { Granted } \\
\text { After } \\
\text { Notice }\end{array}$ & N/A & Unclear & $\begin{array}{l}\text { 54 Days: } \\
\text { Feb 25, } \\
2015 \text { to } \\
\text { April 20, } \\
2015\end{array}$ & Myers & $\begin{array}{l}\text { Attempt to } \\
\text { bring motion } \\
\text { in dismissed } \\
\text { action }\end{array}$ & Yes \\
\hline 24 & $\begin{array}{l}\text { Tunney } v \\
51 \\
\text { Toronto } \\
\text { (City) } \\
\text { Police }\end{array}$ & $\begin{array}{l}24- \\
\text { Apr- } \\
15\end{array}$ & SCJ & Unclear & $\begin{array}{l}{[2015] \text { OJ }} \\
\text { No } 2148\end{array}$ & $\begin{array}{l}2015 \\
\text { Carswell } \\
\text { Ont } 6140\end{array}$ & $\begin{array}{l}\text { Granted } \\
\text { After } \\
\text { Notice }\end{array}$ & N/A & Unclear & $\begin{array}{l}\text { 37 Days: } \\
\text { March } \\
18,2015 \\
\text { to April } \\
24,2015\end{array}$ & Myers & $\begin{array}{l}\text { Purporting to } \\
\text { sue on behalf } \\
\text { of another } \\
\text { without } \\
\text { standing }\end{array}$ & Yes \\
\hline 25 & $\begin{array}{l}\text { Nguyen v } \\
\text { Economic } \\
\text { al Mutual } \\
\text { Insurance } \\
\text { Co }\end{array}$ & $\begin{array}{l}24- \\
\text { Apr- } \\
15\end{array}$ & SCJ & $\begin{array}{l}\text { Respond } \\
\text { ing Party }\end{array}$ & N/A & $\begin{array}{l}2015 \\
\text { ONSC } \\
2646,49 \\
\text { CCLI } \\
\text { (5th) } 144\end{array}$ & $\begin{array}{l}\text { Dismisse } \\
\mathrm{d} \text { in } \\
\text { Context } \\
\text { of Other } \\
\text { Motion }\end{array}$ & N/A & $\begin{array}{l}2,000 \\
\text { (to } \\
\text { Defend } \\
\text { ant } \\
\text { given } \\
\text { other } \\
\text { success) }\end{array}$ & N/A & Dow & $\begin{array}{l}\text { Insurance } \\
\text { claim } \\
\text { (procedural } \\
\text { error by } \\
\text { defendant) }\end{array}$ & Yes \\
\hline 26 & $\begin{array}{l}\text { Salman } v \\
\text { Patey }\end{array}$ & $\begin{array}{l}27- \\
\text { Apr- } \\
15\end{array}$ & SCJ & $\begin{array}{l}\text { Respond } \\
\text { ing Party }\end{array}$ & $\begin{array}{l}2015 \\
\text { ONSC } \\
2727,72 \\
\text { CPC (7th) } \\
368\end{array}$ & N/A & $\begin{array}{l}\text { Notice } \\
\text { Not } \\
\text { Ordered }\end{array}$ & N/A & Unclear & N/A & Myers & $\begin{array}{l}\text { Lawyer's } \\
\text { negligence } \\
\text { (alleged res } \\
\text { judicata) }\end{array}$ & Yes \\
\hline 27 & $\begin{array}{l}\text { Haidari v } \\
\text { Sedeghi- } \\
\text { Pour }\end{array}$ & $\begin{array}{l}04- \\
\text { May- } \\
15\end{array}$ & SCJ & $\begin{array}{l}\text { Respond } \\
\text { ing Party }\end{array}$ & $\begin{array}{l}2015 \\
\text { ONSC } \\
2904,73 \\
\text { CPC (7th) } \\
191\end{array}$ & N/A & $\begin{array}{l}\text { Notice } \\
\text { Not } \\
\text { Ordered }\end{array}$ & N/A & Unclear & N/A & Myers & Car accident & No \\
\hline 28 & $\begin{array}{l}\text { Scaduto v } \\
\text { Law } \\
\text { Society of } \\
\text { Upper } \\
\text { Canada }\end{array}$ & $\begin{array}{l}05- \\
\text { May- } \\
15\end{array}$ & SCJ & $\begin{array}{l}\text { Respond } \\
\text { ing Party }\end{array}$ & $\begin{array}{l}2015 \\
\text { ONSC } \\
2563, \\
{[2015] \text { OJ }} \\
\text { No 2005 }\end{array}$ & N/A & $\begin{array}{l}\text { Granted } \\
\text { After } \\
\text { Notice }\end{array}$ & $\begin{array}{l}\text { Affirme } \\
\text { d: } 2015 \\
\text { ONCA } \\
733,343 \\
\text { OAC } 87, \\
\text { leave to }\end{array}$ & Unclear & $\begin{array}{l}\text { 15 Days: } \\
\text { April 20, } \\
2015 \text { to } \\
\text { May 5, } \\
2015 \text { to } \\
\text { Nov 2, }\end{array}$ & Myers & $\begin{array}{l}\text { Allegations } \\
\text { against } \\
\text { LSUC for } \\
\text { permitting a } \\
\text { lecture }\end{array}$ & Yes \\
\hline
\end{tabular}




\begin{tabular}{|c|c|c|c|c|c|c|c|c|c|c|c|c|c|}
\hline & & & & & & & & $\begin{array}{l}\text { appeal } \\
\text { ref'd, } \\
{[2015]} \\
\text { SCCA } \\
\text { No } 488\end{array}$ & & $\begin{array}{l}2015 \text { to } \\
\text { April 21, } \\
2016\end{array}$ & & & \\
\hline 29 & $\begin{array}{l}\text { Guettler v } \\
\text { Royal } \\
\text { Bank of } \\
\text { Canada }\end{array}$ & $\begin{array}{l}05- \\
\text { May- } \\
15\end{array}$ & SCJ & Unclear & N/A & $\begin{array}{l}2015 \\
\text { ONSC } \\
2905,72 \\
\text { CPC } \\
\text { (7th) } 295\end{array}$ & $\begin{array}{l}\text { Granted } \\
\text { After } \\
\text { Notice }\end{array}$ & N/A & Unclear & $\begin{array}{l}176 \\
\text { Days: } \\
\text { Nov 10, } \\
2014 \text { to } \\
\text { May 5, } \\
2015\end{array}$ & $\begin{array}{l}\text { Di } \\
\text { Tomaso }\end{array}$ & $\begin{array}{l}\text { Wilful } \\
\text { interference } \\
\text { with right to } \\
\text { peaceful life }\end{array}$ & Yes \\
\hline 30 & $\begin{array}{l}\text { Pilieciv } \\
\text { Ontario } \\
\text { (Attorney } \\
\text { General) }\end{array}$ & $\begin{array}{l}25- \\
\text { May- } \\
15\end{array}$ & SCJ & $\begin{array}{l}\text { Respond } \\
\text { ing Party }\end{array}$ & $\begin{array}{l}2015 \\
\text { ONSC } \\
3298, \\
{[2015] \text { OJ }} \\
\text { No 2616 }\end{array}$ & N/A & $\begin{array}{l}\text { Notice } \\
\text { Ordered; } \\
\text { Unclear } \\
\text { Result }\end{array}$ & N/A & Unclear & N/A & Myers & $\begin{array}{l}\text { Attempt to } \\
\text { sue court } \\
\text { staff for how } \\
\text { another } \\
\text { proceeding } \\
\text { was handled }\end{array}$ & Yes \\
\hline 31 & $\begin{array}{l}\text { Brown v } \\
\text { Fred } \\
\text { Victor } \\
\text { Organizat } \\
\text { ion }\end{array}$ & $\begin{array}{l}28- \\
\text { May- } \\
15\end{array}$ & SCJ & $\begin{array}{l}\text { Respond } \\
\text { ing Party }\end{array}$ & $\begin{array}{l}2015 \\
\text { ONSC } \\
2728, \\
{[2015] \text { OJ }} \\
\text { No } 2133\end{array}$ & $\begin{array}{l}2015 \\
\text { ONSC } \\
3421, \\
{[2015]} \\
\text { OJ No } \\
2681\end{array}$ & $\begin{array}{l}\text { Granted } \\
\text { After } \\
\text { Notice }\end{array}$ & N/A & Unclear & $\begin{array}{l}\text { 31 Days: } \\
\text { April 27, } \\
2015 \text { to } \\
\text { May 28, } \\
2015\end{array}$ & Myers & $\begin{array}{l}\text { Not } \\
\text { discernable; } \\
\text { failure to } \\
\text { respond to } \\
\text { offers to } \\
\text { settle }\end{array}$ & Yes \\
\hline 32 & $\begin{array}{l}\text { Keediv } \\
\text { McDonal } \\
\text { d's Corp } \\
\text { Canada }\end{array}$ & $\begin{array}{l}01- \\
\text { Jun-15 }\end{array}$ & SCJ & Unclear & N/A & $\begin{array}{l}2015 \\
\text { ONSC } \\
3516, \\
{[2015]} \\
\text { OJ No } \\
3428\end{array}$ & $\begin{array}{l}\text { Granted } \\
\text { After } \\
\text { Notice }\end{array}$ & N/A & None & $\begin{array}{l}\text { 45 Days: } \\
\text { April 17, } \\
2015 \text { to } \\
\text { June } 1 \text {, } \\
2015\end{array}$ & $\begin{array}{l}\text { Beaudoi } \\
\mathrm{n}\end{array}$ & Unintelligible & Yes \\
\hline 33 & $\begin{array}{l}\text { Becky v } \\
\text { Ontario } \\
\text { (Attorney } \\
\text { General) }\end{array}$ & $\begin{array}{l}04- \\
\text { Jun-15 }\end{array}$ & SCJ & $\begin{array}{l}\text { Respond } \\
\text { ing Party }\end{array}$ & N/A & $\begin{array}{l}\text { [2015] } \\
\text { OJ No } \\
4061, \\
2015 \\
\text { Carswell } \\
\text { Ont } \\
12048\end{array}$ & $\begin{array}{l}\text { Granted } \\
\text { After } \\
\text { Notice }\end{array}$ & N/A & Unclear & $\begin{array}{l}\text { 37 Days: } \\
\text { March } \\
30,2015 \\
\text { to May } \\
6,2015\end{array}$ & Grace & $\begin{array}{l}\text { Upset police } \\
\text { entered } \\
\text { apartment } \\
\text { complex and } \\
\text { sued the } \\
\text { world }\end{array}$ & Yes \\
\hline 34 & $\begin{array}{l}\text { Nemmour } \\
\text { v Durdle }\end{array}$ & $\begin{array}{l}12- \\
\text { Jun-15 }\end{array}$ & SCJ & $\begin{array}{l}\text { Respond } \\
\text { ing Party }\end{array}$ & $\begin{array}{l}2015 \\
\text { ONSC } \\
2561, \\
{[2015] \text { OJ }} \\
\text { No } 1999\end{array}$ & $\begin{array}{l}2015 \\
\text { ONSC } \\
3772, \\
{[2015]} \\
\text { OJ No } \\
3074\end{array}$ & $\begin{array}{l}\text { Granted } \\
\text { After } \\
\text { Notice }\end{array}$ & N/A & Unclear & $\begin{array}{l}53 \text { days: } \\
\text { April 20, } \\
2015 \text { to } \\
\text { June 12, } \\
2015\end{array}$ & Myers & $\begin{array}{l}\text { Allegations } \\
\text { against city re } \\
\text { shelter }\end{array}$ & Yes \\
\hline 35 & $\begin{array}{l}\text { Godzicz v } \\
\text { McPherso } \\
n\end{array}$ & $\begin{array}{l}12- \\
\text { Jun-15 }\end{array}$ & SCJ & Unclear & $\mathrm{N} / \mathrm{A}$ & $\begin{array}{l}2015 \\
\text { ONSC } \\
3776, \\
\text { [2015] } \\
\text { OJ No } \\
3071\end{array}$ & $\begin{array}{l}\text { Granted } \\
\text { After } \\
\text { Notice }\end{array}$ & N/A & Unclear & $\begin{array}{l}\text { 38 Days: } \\
\text { May 5, } \\
2015 \text { to } \\
\text { June } 12, \\
2015\end{array}$ & Myers & $\begin{array}{l}\text { Excessively } \\
\text { long and not } \\
\text { discernable }\end{array}$ & Yes \\
\hline 36 & $\begin{array}{l}\text { Craven v } \\
\text { Chmura }\end{array}$ & $\begin{array}{l}12- \\
\text { Jun-15 }\end{array}$ & SCJ & Unclear & 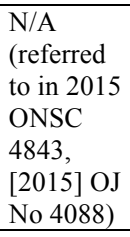 & $\mathrm{N} / \mathrm{A}$ & $\begin{array}{l}\text { Notice } \\
\text { Not } \\
\text { Ordered }\end{array}$ & N/A & Unclear & N/A & Broad & $\begin{array}{l}\text { Motion } \\
\text { within } \\
\text { broader case }\end{array}$ & No \\
\hline
\end{tabular}




\begin{tabular}{|c|c|c|c|c|c|c|c|c|c|c|c|c|c|}
\hline 37 & $\begin{array}{l}\text { Ibrahim v } \\
\text { Toronto } \\
\text { Transit } \\
\text { Commissi } \\
\text { on }\end{array}$ & $\begin{array}{l}17- \\
\text { Jun-15 }\end{array}$ & SCJ & Judge & N/A & $\begin{array}{l}2015 \\
\text { ONSC } \\
3912, \\
{[2015]} \\
\text { OJ No } \\
3155\end{array}$ & $\begin{array}{l}\text { Granted } \\
\text { After } \\
\text { Notice }\end{array}$ & $\begin{array}{l}\text { Affirme } \\
\text { d: } 2016 \\
\text { ONCA } \\
234, \\
\text { [2016] } \\
\text { OJ No } \\
1631 \text {, } \\
\text { leave to } \\
\text { appeal } \\
\text { ref'd, } \\
\text { [2016] } \\
\text { SCCA } \\
\text { No 231 }\end{array}$ & Unclear & $\begin{array}{l}\text { 20 Days: } \\
\text { May 28, } \\
2015 \text { to } \\
\text { June } 17, \\
2015 \text { to } \\
\text { March } \\
31,2016 \\
\text { to Oct } 6 \text {, } \\
2016\end{array}$ & Myers & $\begin{array}{l}\text { Not } \\
\text { something } \\
\text { civil action } \\
\text { can redress }\end{array}$ & Yes \\
\hline 38 & $\begin{array}{l}\text { Vasiliou v } \\
\text { Hallett }\end{array}$ & $\begin{array}{l}19- \\
\text { Jun-15 }\end{array}$ & SCJ & $\begin{array}{l}\text { Respond } \\
\text { ing Party }\end{array}$ & $\begin{array}{l}2015 \\
\text { ONSC } \\
3207, \\
{[2015] \text { OJ }} \\
\text { No } 2567\end{array}$ & $\begin{array}{l}2015 \\
\text { ONSC } \\
3997, \\
{[2015]} \\
\text { OJ No } \\
3227\end{array}$ & $\begin{array}{l}\text { Granted } \\
\text { After } \\
\text { Notice }\end{array}$ & N/A & Unclear & $\begin{array}{l}\text { 30 Days: } \\
\text { May 20, } \\
2015 \text { to } \\
\text { June 19, } \\
2015\end{array}$ & Myers & $\begin{array}{l}\text { Litigation } \\
\text { over will of } \\
\text { mother }\end{array}$ & Yes \\
\hline 39 & $\begin{array}{l}\text { Leev } \\
\text { Future } \\
\text { Bakery } \\
\text { ltd }\end{array}$ & $\begin{array}{l}19- \\
\text { Jun-15 }\end{array}$ & SCJ & $\begin{array}{l}\text { Respond } \\
\text { ing Party }\end{array}$ & $\begin{array}{l}2015 \\
\text { ONSC } \\
3208, \\
{[2015] \text { OJ }} \\
\text { No 2546 }\end{array}$ & $\begin{array}{l}2015 \\
\text { ONSC } \\
3996, \\
{[2015]} \\
\text { OJ No } \\
3217\end{array}$ & $\begin{array}{l}\text { Granted } \\
\text { After } \\
\text { Notice }\end{array}$ & $\mathrm{N} / \mathrm{A}$ & Unclear & $\begin{array}{l}30 \text { Days: } \\
\text { May 20, } \\
2015 \text { to } \\
\text { June } 19 \text {, } \\
2015\end{array}$ & Myers & $\begin{array}{l}\text { Non- } \\
\text { comprehensib } \\
\text { le } \\
\text { interlocutory } \\
\text { step brought }\end{array}$ & Yes \\
\hline 40 & $\begin{array}{l}\text { Posadas v } \\
\text { Khan }\end{array}$ & $\begin{array}{l}23- \\
\text { Jun-15 }\end{array}$ & SCJ & $\begin{array}{l}\text { Respond } \\
\text { ing Party }\end{array}$ & $\begin{array}{l}2015 \\
\text { ONSC } \\
4077,75 \\
\text { CPC (7th) } \\
118\end{array}$ & N/A & $\begin{array}{l}\text { Notice } \\
\text { Not } \\
\text { Ordered }\end{array}$ & $\mathrm{N} / \mathrm{A}$ & Unclear & N/A & Myers & $\begin{array}{l}\text { Badly } \\
\text { phrased } \\
\text { counterclaims }\end{array}$ & $\begin{array}{l}\text { Yes } \\
\text { (but } \\
\text { lawy } \\
\text { er) }\end{array}$ \\
\hline 41 & $\begin{array}{l}\text { Asghar v } \\
\text { Ontario }\end{array}$ & $\begin{array}{l}23- \\
\text { Jun-15 }\end{array}$ & SCJ & $\begin{array}{l}\text { Respond } \\
\text { ing Party }\end{array}$ & $\begin{array}{l}2015 \\
\text { ONSC } \\
4071, \\
{[2015] \text { OJ }} \\
\text { No 3326 }\end{array}$ & $\mathrm{N} / \mathrm{A}$ & $\begin{array}{l}\text { Notice } \\
\text { Ordered; } \\
\text { Unclear } \\
\text { Result }\end{array}$ & $\mathrm{N} / \mathrm{A}$ & Unclear & N/A & Myers & $\begin{array}{l}\text { Asks } \\
\text { province to } \\
\text { provide job, } \\
\text { fix romance } \\
\text { issues, etc. }\end{array}$ & Yes \\
\hline 42 & $\begin{array}{l}\text { Raji v } \\
\text { Myers }\end{array}$ & $\begin{array}{l}23- \\
\text { Jun-15 }\end{array}$ & SCJ & Unclear & N/A & $\begin{array}{l}2015 \\
\text { ONSC } \\
4066,75 \\
\text { CPC } \\
\text { (7th) } 115\end{array}$ & $\begin{array}{l}\text { Granted } \\
\text { After } \\
\text { Notice }\end{array}$ & N/A & Unclear & N/A & $\begin{array}{l}\text { Beaudoi } \\
\mathrm{n}\end{array}$ & Sues Myers J & Yes \\
\hline 43 & $\begin{array}{l}\text { Clancy v } \\
\text { Ontario }\end{array}$ & $\begin{array}{l}29- \\
\text { Jun-15 }\end{array}$ & SCJ & Unclear & N/A & $\begin{array}{l}2015 \\
\text { ONSC } \\
4194, \\
{[2015]} \\
\text { OJ No } \\
3422\end{array}$ & $\begin{array}{l}\text { Granted } \\
\text { After } \\
\text { Notice }\end{array}$ & N/A & Unclear & $\begin{array}{l}116 \\
\text { days: } \\
\text { March 5, } \\
2015 \text { to } \\
\text { June 29, } \\
2015\end{array}$ & $\begin{array}{l}\text { Johnsto } \\
\mathrm{n}\end{array}$ & $\begin{array}{l}\text { Attempt to } \\
\text { re-litigate }\end{array}$ & Yes \\
\hline 44 & $\begin{array}{l}\text { Hurontari } \\
\text { o Travel } \\
\text { Centre v } \\
\text { Ontario } \\
\text { (Attorney } \\
\text { General) }\end{array}$ & $\begin{array}{l}30- \\
\text { Jun-15 }\end{array}$ & SCJ & $\begin{array}{l}\text { Respond } \\
\text { ing Party }\end{array}$ & $\begin{array}{l}2015 \\
\text { ONSC } \\
3296, \\
{[2015] \text { OJ }} \\
\text { No 2613 }\end{array}$ & $\begin{array}{l}2015 \\
\text { ONSC } \\
4246, \\
{[2015]} \\
\text { OJ No } \\
3469\end{array}$ & $\begin{array}{l}\text { Granted } \\
\text { After } \\
\text { Notice }\end{array}$ & N/A & Unclear & $\begin{array}{l}\text { 36 Days: } \\
\text { May 25, } \\
2015 \text { to } \\
\text { June } 30 \text {, } \\
2015\end{array}$ & Myers & $\begin{array}{l}\text { Attempt to } \\
\text { re-litigate }\end{array}$ & Yes \\
\hline
\end{tabular}




\begin{tabular}{|c|c|c|c|c|c|c|c|c|c|c|c|c|c|}
\hline 45 & $\begin{array}{l}\text { Maden } v \\
\text { Longstree } \\
t\end{array}$ & $\begin{array}{l}30- \\
\text { Jun-15 }\end{array}$ & SCJ & $\begin{array}{l}\text { Respond } \\
\text { ing Party }\end{array}$ & $\begin{array}{l}2015 \\
\text { ONSC } \\
3425, \\
{[2015] \text { OJ }} \\
\text { No 2691 }\end{array}$ & $\begin{array}{l}2015 \\
\text { ONSC } \\
4247, \\
{[2015]} \\
\text { OJ No } \\
3473\end{array}$ & $\begin{array}{l}\text { Granted } \\
\text { After } \\
\text { Notice }\end{array}$ & N/A & None & $\begin{array}{l}\text { 34 Days: } \\
\text { May 27, } \\
2015 \text { to } \\
\text { June } 30 \text {, } \\
2015\end{array}$ & Myers & $\begin{array}{l}\text { Not } \\
\text { discernable } \\
\text { claim against } \\
\text { lawyer }\end{array}$ & Yes \\
\hline 46 & $\begin{array}{l}\text { Persaud v } \\
\text { Boundry } \\
\text { Road } \\
\text { Apts Ltd }\end{array}$ & $\begin{array}{l}02- \\
\text { Jul-15 }\end{array}$ & SCJ & $\begin{array}{l}\text { Respond } \\
\text { ing Party }\end{array}$ & N/A & $\begin{array}{l}2015 \\
\text { ONSC } \\
4275, \\
{[2015]} \\
\text { OJ No } \\
3586\end{array}$ & $\begin{array}{l}\text { Granted } \\
\text { After } \\
\text { Notice }\end{array}$ & N/A & Unclear & N/A & Daley & $\begin{array}{l}\text { Unintelligible } \\
\text {, attempt to } \\
\text { re-litigate, no } \\
\text { standing }\end{array}$ & Yes \\
\hline 47 & $\begin{array}{l}\text { Allevio } \\
\text { Healthcar } \\
\text { e Inc v } \\
\text { Kirsh }\end{array}$ & $\begin{array}{l}14- \\
\text { Jul-15 }\end{array}$ & SCJ & $\begin{array}{l}\text { Respond } \\
\text { ing Party }\end{array}$ & $\begin{array}{l}2015 \\
\text { ONSC } \\
4539,77 \\
\text { CPC (7th) } \\
211\end{array}$ & N/A & $\begin{array}{l}\text { Notice } \\
\text { Not } \\
\text { Ordered }\end{array}$ & N/A & Unclear & N/A & Myers & $\begin{array}{l}\text { Defamation } \\
\text { claim based } \\
\text { on privileged } \\
\text { communicati } \\
\text { ons - requires } \\
\text { hearing }\end{array}$ & $\begin{array}{l}\text { Uncl } \\
\text { ear }\end{array}$ \\
\hline 48 & $\begin{array}{l}\text { Asghar v } \\
\text { Toronto } \\
\text { (City) }\end{array}$ & $\begin{array}{l}20- \\
\text { Jul-15 }\end{array}$ & SCJ & $\begin{array}{l}\text { Respond } \\
\text { ing Party }\end{array}$ & $\begin{array}{l}2015 \\
\text { ONSC } \\
4075, \\
{[2015] \text { OJ }} \\
\text { No 3325 }\end{array}$ & $\begin{array}{l}\frac{2015}{\mathrm{ONSC}} \\
\frac{4650,42}{\text { MPLR }} \\
\frac{(5 \text { th }) 138}{4} \\
\end{array}$ & $\begin{array}{l}\text { Granted } \\
\text { After } \\
\text { Notice }\end{array}$ & N/A & Unclear & $\begin{array}{l}\text { 27 Days: } \\
\text { June 23, } \\
2015 \text { to } \\
\text { July 20, } \\
2015\end{array}$ & Myers & $\begin{array}{l}\text { Sued city } \\
\text { after } \\
\text { lifeguard said } \\
\text { he was } \\
\text { swimming } \\
\text { too slowly in } \\
\text { fast lane }\end{array}$ & Yes \\
\hline 49 & $\begin{array}{l}\text { Kadiri v } \\
\text { Harikuma } \\
r\end{array}$ & $\begin{array}{l}04- \\
\text { Aug- } \\
15\end{array}$ & SCJ & $\begin{array}{l}\text { Respond } \\
\text { ing Party }\end{array}$ & $\begin{array}{l}2015 \\
\text { ONSC } \\
3777, \\
{[2015] \text { OJ }} \\
\text { No 3073 }\end{array}$ & $\begin{array}{l}2015 \\
\text { ONSC } \\
4894, \\
{[2015]} \\
\text { OJ No } \\
4103\end{array}$ & $\begin{array}{l}\text { Granted } \\
\text { After } \\
\text { Notice }\end{array}$ & N/A & $\begin{array}{l}\text { Unclear } \\
\text { (Substa } \\
\text { ntial) }\end{array}$ & $\begin{array}{l}53 \text { Days: } \\
\text { June 12, } \\
2015 \text { to } \\
\text { Aug 4, } \\
2015\end{array}$ & Myers & $\begin{array}{l}\text { Allegation } \\
\text { that baby was } \\
\text { stolen }\end{array}$ & Yes \\
\hline 50 & $\begin{array}{l}\text { Cheng v } \\
\text { Lee }\end{array}$ & $\begin{array}{l}14- \\
\text { Aug- } \\
15\end{array}$ & SCJ & $\begin{array}{l}\text { Respond } \\
\text { ing Party }\end{array}$ & $\begin{array}{l}2015 \\
\text { ONSC } \\
5148,77 \\
\text { CPC (7th) } \\
141\end{array}$ & N/A & $\begin{array}{l}\text { Notice } \\
\text { Not } \\
\text { Ordered }\end{array}$ & N/A & Unclear & N/A & Myers & $\begin{array}{l}\text { Accusations } \\
\text { of sabotaging } \\
\text { business } \\
\text { (\$25M } \\
\text { counterclaim } \\
\text { on } \$ 30 \mathrm{~K} \\
\text { claim) }\end{array}$ & Yes \\
\hline 51 & $\begin{array}{l}\text { Tunney v } \\
\text { Crew \& } \\
\text { Tango }\end{array}$ & $\begin{array}{l}15- \\
\text { Aug- } \\
14\end{array}$ & SCJ & $\begin{array}{l}\text { Respond } \\
\text { ing Party }\end{array}$ & $\begin{array}{l}2015 \\
\text { ONSC } \\
4537, \\
{[2015] \text { OJ }} \\
\text { No 3875 }\end{array}$ & $\begin{array}{l}2015 \\
\text { ONSC } \\
5140, \\
2015 \\
\text { Carswell } \\
\text { Ont } \\
12347\end{array}$ & $\begin{array}{l}\text { Granted } \\
\text { After } \\
\text { Notice }\end{array}$ & N/A & Unclear & $\begin{array}{l}\text { 31 Days: } \\
\text { July 14, } \\
2015 \text { to } \\
\text { Aug 14, } \\
2015\end{array}$ & Myers & $\begin{array}{l}\text { Plaintiff } \\
\text { upset police } \\
\text { arrested his } \\
\text { tenant }\end{array}$ & Yes \\
\hline 52 & $\begin{array}{l}\text { Ebriniss v } \\
D^{\prime} \text { Ovidio }\end{array}$ & $\begin{array}{l}24- \\
\text { Aug- } \\
15\end{array}$ & SCJ & $\begin{array}{l}\text { Respond } \\
\text { ing Party }\end{array}$ & $\begin{array}{l}2015 \\
\text { ONSC } \\
4649, \\
{[2015] \text { OJ }} \\
\text { No } 3842\end{array}$ & $\begin{array}{l}2015 \\
\text { ONSC } \\
5295, \\
{[2015]} \\
\text { OJ No } \\
4446\end{array}$ & $\begin{array}{l}\text { Granted } \\
\text { After } \\
\text { Notice }\end{array}$ & N/A & Unclear & $\begin{array}{l}\text { 35 Days: } \\
\text { July 20, } \\
2015 \text { to } \\
\text { Aug 24, } \\
2015\end{array}$ & Myers & $\begin{array}{l}\text { Baseless } \\
\text { claim in } \\
\text { occupier's } \\
\text { liability - on } \\
\text { its face } \\
\text { cannot } \\
\text { succeed } \\
\text { (acknowledge } \\
\text { s self-reps } \\
\text { need help) }\end{array}$ & Yes \\
\hline
\end{tabular}




\begin{tabular}{|c|c|c|c|c|c|c|c|c|c|c|c|c|c|}
\hline 53 & $\begin{array}{l}\text { Gallion v } \\
\text { Ontario } \\
\text { Mortgage } \\
\text { Corp }\end{array}$ & $\begin{array}{l}25- \\
\text { Aug- } \\
15\end{array}$ & SCJ & $\begin{array}{l}\text { Respond } \\
\text { ing Party }\end{array}$ & $\begin{array}{l}2015 \\
\text { ONSC } \\
4770, \\
{[2015] \text { OJ }} \\
\text { No } 3966\end{array}$ & $\begin{array}{l}2015 \\
\text { ONSC } \\
5320 \\
{[2015]} \\
\text { OJ No } \\
4433\end{array}$ & $\begin{array}{l}\text { Granted } \\
\text { After } \\
\text { Notice }\end{array}$ & N/A & None & $\begin{array}{l}29 \text { Days: } \\
\text { July 27, } \\
2015 \text { to } \\
\text { Aug } 25 \text {, } \\
2015\end{array}$ & Myers & $\begin{array}{l}\text { Eviction } 35 \\
\text { years ago }\end{array}$ & Yes \\
\hline 54 & $\begin{array}{l}\text { Asghar v } \\
\text { Avepoint } \\
\text { Toronto }\end{array}$ & $\begin{array}{l}04- \\
\text { Sep- } \\
15\end{array}$ & SCJ & $\begin{array}{l}\text { Respond } \\
\text { ing Party }\end{array}$ & $\begin{array}{l}2015 \\
\text { ONSC } \\
5164, \\
{[2015] \text { OJ }} \\
\text { No 4331 }\end{array}$ & $\begin{array}{l}\frac{2015}{\overline{\mathrm{ONSC}}} \\
5544, \\
2015] \\
\underline{\text { OJ No }} \\
\underline{4611} \\
\end{array}$ & $\begin{array}{l}\text { Granted } \\
\text { After } \\
\text { Notice }\end{array}$ & N/A & None & $\begin{array}{l}21 \text { Days: } \\
\text { Aug 14, } \\
2015 \text { to } \\
\text { Sept } 4 \text {, } \\
2015\end{array}$ & Myers & $\begin{array}{l}\text { Defendant } \\
\text { offered and } \\
\text { then reneged } \\
\text { on job } \\
\text { interview }\end{array}$ & Yes \\
\hline 55 & $\begin{array}{l}\text { Kyriakop } \\
\text { oulos v } \\
\text { Lafontain } \\
e\end{array}$ & $\begin{array}{l}30- \\
\text { Sep- } \\
15\end{array}$ & SCJ & $\begin{array}{l}\text { Respond } \\
\text { ing Party }\end{array}$ & $\begin{array}{l}2015 \\
\text { ONSC } \\
6067, \\
{[2015] \text { OJ }} \\
\text { No } 5029\end{array}$ & $\mathrm{~N} / \mathrm{A}$ & $\begin{array}{l}\text { Notice } \\
\text { Not } \\
\text { Ordered }\end{array}$ & N/A & Unclear & N/A & Myers & $\begin{array}{l}\text { "Wholly } \\
\text { inappropriate } \\
\text { use of Rule } \\
2.1 "\end{array}$ & No \\
\hline 56 & $\begin{array}{l}\text { Mesa v } \\
\text { TD Direct } \\
\text { Investmen } \\
t\end{array}$ & $\begin{array}{l}14- \\
\text { Oct-15 }\end{array}$ & SCJ & $\begin{array}{l}\text { Respond } \\
\text { ing Party }\end{array}$ & $\begin{array}{l}2015 \\
\text { ONSC } \\
5543, \\
{[2015] \text { OJ }} \\
\text { No 4589 }\end{array}$ & $\begin{array}{l}2015 \\
\text { ONSC } \\
6337 \\
{[2015]} \\
\text { OJ No } \\
5292\end{array}$ & $\begin{array}{l}\text { Granted } \\
\text { After } \\
\text { Notice }\end{array}$ & N/A & Unclear & $\begin{array}{l}\text { 40 Days: } \\
\text { Sept 4, } \\
2015 \text { to } \\
\text { Oct } 14 \text {, } \\
2015\end{array}$ & Myers & $\begin{array}{l}\text { Alleged } \\
\text { failure to pay } \\
\text { over } \\
\text { investment }\end{array}$ & Yes \\
\hline 57 & $\begin{array}{l}\text { Fine v } \\
\text { Botelho }\end{array}$ & $\begin{array}{l}15- \\
\text { Oct-15 }\end{array}$ & SCJ & $\begin{array}{l}\text { Respond } \\
\text { ing Party }\end{array}$ & $\mathrm{N} / \mathrm{A}$ & $\begin{array}{l}2015 \\
\text { ONSC } \\
6284 \\
{[2015]} \\
\text { OJ No } \\
5321\end{array}$ & $\begin{array}{l}\text { Dismisse } \\
\mathrm{d} \text { in } \\
\text { Context } \\
\text { of Other } \\
\text { Motion }\end{array}$ & N/A & $\begin{array}{l}\text { Not } \\
\text { Applica } \\
\text { ble } \\
\text { (other } \\
\text { issues) }\end{array}$ & $\mathrm{N} / \mathrm{A}$ & Graham & $\begin{array}{l}\text { Declined to } \\
\text { use in context } \\
\text { of broader } \\
\text { motion }\end{array}$ & Yes \\
\hline 58 & $\begin{array}{l}\text { Rajiv } \\
\text { Canada } \\
(\text { RCMP) }\end{array}$ & $\begin{array}{l}16- \\
\text { Oct-15 }\end{array}$ & SCJ & $\begin{array}{l}\text { Respond } \\
\text { ing Party }\end{array}$ & $\begin{array}{l}2015 \\
\text { ONSC } \\
5414, \\
{[2015] \text { OJ }} \\
\text { No 4515 }\end{array}$ & $\begin{array}{l}2015 \\
\text { ONSC } \\
6392, \\
{[2015]} \\
\text { OJ No } \\
5486\end{array}$ & $\begin{array}{l}\text { Granted } \\
\text { After } \\
\text { Notice }\end{array}$ & N/A & Unclear & $\begin{array}{l}53 \text { Days: } \\
\text { Aug 24, } \\
2015 \text { to } \\
\text { Oct } 16 \text {, } \\
2015\end{array}$ & $\begin{array}{l}\text { Beaudoi } \\
\mathrm{n}\end{array}$ & $\begin{array}{l}\text { Massive } \\
\text { attempt to re- } \\
\text { litigate } \\
\text { terrorist plot } \\
\text { against } \\
\text { plaintiff }\end{array}$ & Yes \\
\hline 59 & $\begin{array}{l}\text { Rajiv } \\
\text { Downtow } \\
n \text { Legal } \\
\text { Services }\end{array}$ & $\begin{array}{l}16- \\
\text { Oct-15 }\end{array}$ & SCJ & $\begin{array}{l}\text { Respond } \\
\text { ing Party }\end{array}$ & $\begin{array}{l}2015 \\
\text { ONSC } \\
5770, \\
{[2015] \text { OJ }} \\
\text { No 4812 }\end{array}$ & $\begin{array}{l}2015 \\
\text { ONSC } \\
6391, \\
{[2015]} \\
\text { OJ No } \\
5474\end{array}$ & $\begin{array}{l}\text { Granted } \\
\text { After } \\
\text { Notice }\end{array}$ & N/A & Unclear & $\begin{array}{l}\text { 29 Days: } \\
\text { Sept } 17 \text {, } \\
2015 \text { to } \\
\text { Oct } 16 \text {, } \\
2015\end{array}$ & $\begin{array}{l}\text { Beaudoi } \\
\mathrm{n}\end{array}$ & $\begin{array}{l}\text { Collateral } \\
\text { attack on } \\
\text { provincial } \\
\text { court } \\
\text { decision }\end{array}$ & Yes \\
\hline 60 & $\begin{array}{l}\text { Grigorov } \\
v \text { Booth }\end{array}$ & $\begin{array}{l}04- \\
\text { Nov- } \\
15\end{array}$ & SCJ & $\begin{array}{l}\text { Respond } \\
\text { ing Party }\end{array}$ & $\begin{array}{l}2015 \\
\text { ONSC } \\
6066, \\
{[2015] \text { OJ }} \\
\text { No 5025 }\end{array}$ & $\begin{array}{l}2015 \\
\text { ONSC } \\
6804 \\
{[2015]} \\
\text { OJ No } \\
5745\end{array}$ & $\begin{array}{l}\text { Granted } \\
\text { After } \\
\text { Notice }\end{array}$ & N/A & Unclear & $\begin{array}{l}\text { 35 Days: } \\
\text { Sept 30, } \\
2015 \text { to } \\
\text { Nov 4, } \\
2015\end{array}$ & Myers & $\begin{array}{l}\text { Lawyer's } \\
\text { Negligence }\end{array}$ & Yes \\
\hline 61 & $\begin{array}{l}\text { Minor } v \\
\text { Leonard }\end{array}$ & $\begin{array}{l}04- \\
\text { Nov- } \\
15\end{array}$ & SCJ & $\begin{array}{l}\text { Respond } \\
\text { ing Party }\end{array}$ & $\begin{array}{l}2015 \\
\text { ONSC } \\
6069, \\
{[2015] \text { OJ }} \\
\text { No 5293 }\end{array}$ & $\begin{array}{l}2015 \\
\text { ONSC } \\
6801, \\
{[2015]} \\
\text { OJ No } \\
5744\end{array}$ & $\begin{array}{l}\text { Granted } \\
\text { After } \\
\text { Notice }\end{array}$ & N/A & $\begin{array}{l}\text { Unclear } \\
\text { ("with } \\
\text { costs") }\end{array}$ & $\begin{array}{l}\text { 35 Days: } \\
\text { Sept 30, } \\
2015 \text { to } \\
\text { Nov 4, } \\
2015\end{array}$ & Myers & $\begin{array}{l}\text { Damages } \\
\text { based on } \\
\text { absolutely } \\
\text { privileged } \\
\text { events from } \\
\text { previous } \\
\text { cases }\end{array}$ & Yes \\
\hline
\end{tabular}




\begin{tabular}{|c|c|c|c|c|c|c|c|c|c|c|c|c|c|}
\hline 62 & $\begin{array}{l}\text { Obermull } \\
\text { er } v \\
\text { Kenfinch } \\
\text { Co- } \\
\text { Operative } \\
\text { Housing } \\
\text { Inc }\end{array}$ & $\begin{array}{l}04- \\
\text { Nov- } \\
15\end{array}$ & SCJ & $\begin{array}{l}\text { Respond } \\
\text { ing Party }\end{array}$ & $\begin{array}{l}2015 \\
\text { ONSC } \\
6065, \\
{[2015] \text { OJ }} \\
\text { No 5031 }\end{array}$ & $\begin{array}{l}2015 \\
\text { ONSC } \\
6800, \\
{[2015]} \\
\text { OJ No } \\
5743\end{array}$ & $\begin{array}{l}\text { Granted } \\
\text { After } \\
\text { Notice }\end{array}$ & $\begin{array}{l}\text { Affirme } \\
\text { d: } 2016 \\
\text { ONCA } \\
330, \\
{[2016]} \\
\text { OJ No } \\
2362\end{array}$ & $\begin{array}{l}\text { Unclear } \\
\text { (trial); } \\
\$ 2,000 \\
\text { (appeal) }\end{array}$ & $\begin{array}{l}35 \text { Days: } \\
\text { Sept 30, } \\
2015 \text { to } \\
\text { Nov 4, } \\
2015 \text { to } \\
\text { May 3, } \\
2016\end{array}$ & Myers & $\begin{array}{l}\text { Attempt to } \\
\text { re-litigate } \\
\text { Landlord- } \\
\text { Tenant Board } \\
\text { proceedings }\end{array}$ & Yes \\
\hline 63 & $\begin{array}{l}\text { Charendo } \\
\text { ff } v \\
\text { McLenna } \\
n\end{array}$ & $\begin{array}{l}09- \\
\text { Nov- } \\
15\end{array}$ & SCJ & $\begin{array}{l}\text { Respond } \\
\text { ing Party }\end{array}$ & $\begin{array}{l}2015 \\
\text { ONSC } \\
6883, \\
{[2015] \text { OJ }} \\
\text { No } 6469\end{array}$ & N/A & $\begin{array}{l}\text { Notice } \\
\text { Not } \\
\text { Ordered }\end{array}$ & N/A & None & N/A & Myers & $\begin{array}{l}\text { Questionable } \\
\text { late attempt } \\
\text { to add } \\
\text { plaintiff's } \\
\text { lawyer as } \\
\text { third party }\end{array}$ & No \\
\hline 64 & $\begin{array}{l}\text { Kavuru v } \\
\text { Ontario } \\
\text { (Public } \\
\text { Guardian } \\
\text { and } \\
\text { Trustee) }\end{array}$ & $\begin{array}{l}09- \\
\text { Nov- } \\
15\end{array}$ & SCJ & $\begin{array}{l}\text { Respond } \\
\text { ing Party }\end{array}$ & $\begin{array}{l}2015 \\
\text { ONSC } \\
6344, \\
{[2015] \text { OJ }} \\
\text { No 5288 }\end{array}$ & $\begin{array}{l}2015 \\
\text { ONSC } \\
6877, \\
2015 \\
\text { Carswell } \\
\text { Ont } \\
18764 \\
\text { (partial); } \\
2015 \\
\text { ONSC } \\
7697, \\
\text { [2015] } \\
\text { OJ No } \\
6468 \\
\text { (full) }\end{array}$ & $\begin{array}{l}\text { Granted } \\
\text { After } \\
\text { Notice }\end{array}$ & $\begin{array}{l}\text { Affirme } \\
\text { d: } 2016 \\
\text { ONCA } \\
758, \\
{[2016]} \\
\text { OJ No } \\
5557\end{array}$ & Unclear & $\begin{array}{l}\text { 27 Days: } \\
\text { Oct 13, } \\
2015 \text { to } \\
\text { Nov 9, } \\
2015 \text { (to } \\
\text { Dec } 9 \text {, } \\
2015 \text { to } \\
\text { Oct } 14 \text {, } \\
2016 \text { ) }\end{array}$ & Myers & $\begin{array}{l}\text { Suit against } \\
\text { A-G due to } \\
\text { decision of } \\
\text { Divisional } \\
\text { Court and } \\
\text { other claims } \\
\text { against PGT }\end{array}$ & Yes \\
\hline 65 & $\begin{array}{l}\text { Perkins- } \\
\text { Aboagye } \\
v \text { Becker }\end{array}$ & $\begin{array}{l}26- \\
\text { Nov- } \\
15\end{array}$ & SCJ & $\begin{array}{l}\text { Respond } \\
\text { ing Party }\end{array}$ & $\begin{array}{l}2015 \\
\text { ONSC } \\
6812, \\
{[2015] \text { OJ }} \\
\text { No } 6472\end{array}$ & $\begin{array}{l}2015 \\
\text { ONSC } \\
7366, \\
{[2015]} \\
\text { OJ No } \\
6291\end{array}$ & $\begin{array}{l}\text { Granted } \\
\text { After } \\
\text { Notice }\end{array}$ & N/A & Unclear & $\begin{array}{l}23 \text { Days: } \\
\text { Nov 3, } \\
2015 \text { to } \\
\text { Nov 26, } \\
2015\end{array}$ & $\begin{array}{l}\text { Beaudoi } \\
\mathrm{n}\end{array}$ & $\begin{array}{l}\text { Attempt to } \\
\text { re-litigate }\end{array}$ & Yes \\
\hline 66 & $\begin{array}{l}\text { Hagey v } \\
\text { Ontario } \\
\text { (Racing } \\
\text { Commissi } \\
\text { on) }\end{array}$ & $\begin{array}{l}27- \\
\text { Nov- } \\
15\end{array}$ & SCJ & Unclear & N/A & $\begin{array}{l}2015 \\
\text { ONSC } \\
7506, \\
{[2015]} \\
\text { OJ No } \\
6203\end{array}$ & $\begin{array}{l}\text { Granted } \\
\text { After } \\
\text { Notice }\end{array}$ & N/A & Unclear & Unclear & Nadeau & $\begin{array}{l}\text { Claim for } \\
\text { breach of } \\
\text { procedural } \\
\text { fairness by } \\
\text { Racing } \\
\text { Commission }\end{array}$ & Yes \\
\hline 67 & $\begin{array}{l}\text { Nguyen v } \\
\text { Economic } \\
\text { al Mutual } \\
\text { Insurance } \\
\text { Co }\end{array}$ & $\begin{array}{l}01- \\
\text { Dec- } \\
15\end{array}$ & SCJ & Unclear & $\begin{array}{l}2015 \\
\text { ONSC } \\
6802, \\
{[2015] \text { OJ }} \\
\text { No } 5723\end{array}$ & $\begin{array}{l}2015 \\
\text { ONSC } \\
7449, \\
{[2015]} \\
\text { OJ No } \\
6251\end{array}$ & $\begin{array}{l}\text { Granted } \\
\text { After } \\
\text { Notice }\end{array}$ & N/A & None & $\begin{array}{l}27 \text { Days: } \\
\text { Nov 4, } \\
2015 \text { to } \\
\text { Dec } 1 \text {, } \\
2015\end{array}$ & Myers & $\begin{array}{l}\text { Attempt to } \\
\text { re-litigate }\end{array}$ & Yes \\
\hline 68 & $\begin{array}{l}\text { Munroe v } \\
\text { Salvation } \\
\text { Army }\end{array}$ & $\begin{array}{l}01- \\
\text { Dec- } \\
15\end{array}$ & SCJ & $\begin{array}{l}\text { Respond } \\
\text { ing Party }\end{array}$ & $\begin{array}{l}2015 \\
\text { ONSC } \\
7448, \\
{[2015] \text { OJ }} \\
\text { No } 6220\end{array}$ & N/A & $\begin{array}{l}\text { Lack of } \\
\text { Notice } \\
\text { Reconsi } \\
\text { dered: } \\
2016 \\
\text { ONSC } \\
5564, \\
{[2016]} \\
\text { OJ No } \\
4643\end{array}$ & N/A & Unclear & N/A & Myers & $\begin{array}{l}\text { Wrongful } \\
\text { dismissal } \\
\text { with } \\
\text { outrageous } \\
\text { facts }\end{array}$ & Yes \\
\hline
\end{tabular}




\begin{tabular}{|c|c|c|c|c|c|c|c|c|c|c|c|c|c|}
\hline 69 & $\begin{array}{l}\text { Gebremar } \\
\text { iam v } \\
\text { Toronto } \\
\text { (City) } \\
\text { Police } \\
\text { Service }\end{array}$ & $\begin{array}{l}01- \\
\text { Dec- } \\
15\end{array}$ & SCJ & $\begin{array}{l}\text { Respond } \\
\text { ing Party }\end{array}$ & $\begin{array}{l}2015 \\
\text { ONSC } \\
7447, \\
{[2015] \text { OJ }} \\
\text { No } 6243\end{array}$ & N/A & $\begin{array}{l}\text { Notice } \\
\text { Not } \\
\text { Ordered }\end{array}$ & N/A & Unclear & N/A & Myers & $\begin{array}{l}\text { Police } \\
\text { brutality }\end{array}$ & $\begin{array}{l}\text { Uncl } \\
\text { ear }\end{array}$ \\
\hline 70 & $\begin{array}{l}\text { Ghasemp } \\
\text { oor v } \\
\text { DSM } \\
\text { Leasing } \\
\text { Ltd }\end{array}$ & $\begin{array}{l}07- \\
\text { Dec- } \\
15\end{array}$ & $\mathrm{SCJ}$ & $\begin{array}{l}\text { Respond } \\
\text { ing Party }\end{array}$ & $\begin{array}{l}2015 \\
\text { ONSC } \\
7628, \\
{[2015] \text { OJ }} \\
\text { No } 6422\end{array}$ & $\mathrm{~N} / \mathrm{A}$ & $\begin{array}{l}\text { Notice } \\
\text { Not } \\
\text { Ordered }\end{array}$ & N/A & Unclear & N/A & Myers & $\begin{array}{l}\text { Equipment } \\
\text { lease }\end{array}$ & Yes \\
\hline 71 & $\begin{array}{l}\text { Shafirovit } \\
\text { ch } v \\
\text { Scarboro } \\
\text { ugh } \\
\text { Hospital }\end{array}$ & $\begin{array}{l}07- \\
\text { Dec- } \\
15\end{array}$ & SCJ & $\begin{array}{l}\text { Respond } \\
\text { ing Party }\end{array}$ & $\begin{array}{l}\text { Dismisse } \\
\text { d without } \\
\text { notice }\end{array}$ & $\begin{array}{l}\frac{2015}{\mathrm{ONSC}} \\
\frac{7627,85}{\mathrm{CPC}} \\
\frac{(7 \mathrm{th})}{149} \\
\end{array}$ & $\begin{array}{l}\text { Granted } \\
\text { Without } \\
\text { Notice }\end{array}$ & N/A & None & 0 Days & Myers & $\begin{array}{l}\text { Belief } \\
\text { hospital } \\
\text { threw bugs at } \\
\text { him }\end{array}$ & Yes \\
\hline 72 & $\begin{array}{l}\text { Brown v } \\
\text { Loblaws } \\
\text { Companie } \\
\text { s Ltd }\end{array}$ & $\begin{array}{l}07- \\
\text { Dec- } \\
15\end{array}$ & SCJ & $\begin{array}{l}\text { Respond } \\
\text { ing Party }\end{array}$ & $\begin{array}{l}2015 \\
\text { ONSC } \\
6501, \\
{[2015] \text { OJ }} \\
\text { No } 5440\end{array}$ & $\begin{array}{l}2015 \\
\text { ONSC } \\
7629, \\
{[2015]} \\
\text { OJ No } \\
6394\end{array}$ & $\begin{array}{l}\text { Granted } \\
\text { After } \\
\text { Notice }\end{array}$ & $\mathrm{N} / \mathrm{A}$ & None & $\begin{array}{l}\text { 47 Days: } \\
\text { Oct } 21 \text {, } \\
2015 \text { to } \\
\text { Dec } 7 \text {, } \\
2015\end{array}$ & Myers & $\begin{array}{l}\text { Claims } \\
\text { related to } \\
\text { denied credit } \\
\text { card } \\
\text { application }\end{array}$ & Yes \\
\hline 73 & $\begin{array}{l}\text { Asghar v } \\
\text { Alon }\end{array}$ & $\begin{array}{l}14- \\
\text { Dec- } \\
15\end{array}$ & SCJ & $\begin{array}{l}\text { Respond } \\
\text { ing Party }\end{array}$ & $\begin{array}{l}\frac{2015}{\mathrm{ONSC}} \\
\frac{3835,74}{\mathrm{CPC}(7 \mathrm{th})} \\
\frac{311}{\underline{11}}\end{array}$ & $\begin{array}{l}2015 \\
\text { ONSC } \\
7823, \\
\text { [2015] } \\
\text { OJ No } \\
6573\end{array}$ & $\begin{array}{l}\text { Dismisse } \\
\text { d After } \\
\text { Notice }\end{array}$ & $\mathrm{N} / \mathrm{A}$ & Unclear & $\begin{array}{l}182 \\
\text { Days: } \\
\text { June 15, } \\
2015 \text { to } \\
\text { Dec 14, } \\
2015\end{array}$ & Myers & Libel & Yes \\
\hline 74 & $\begin{array}{l}\text { MacLeod } \\
v \text { Bell } \\
\text { Canada } \\
\text { Enterpris } \\
\text { es }\end{array}$ & $\begin{array}{l}22- \\
\text { Dec- } \\
15\end{array}$ & SCJ & $\begin{array}{l}\text { Respond } \\
\text { ing Party }\end{array}$ & $\begin{array}{l}2015 \\
\text { ONSC } \\
7116, \\
\text { [2015] OJ } \\
\text { No 5958 }\end{array}$ & $\begin{array}{l}2015 \\
\text { ONSC } \\
8019, \\
{[2015]} \\
\text { OJ No } \\
6770\end{array}$ & $\begin{array}{l}\text { Granted } \\
\text { After } \\
\text { Notice }\end{array}$ & N/A & None & $\begin{array}{l}\text { 35 Days: } \\
\text { Nov 17, } \\
2015 \text { to } \\
\text { Dec 22, } \\
2015\end{array}$ & Myers & $\begin{array}{l}\text { Simply gave } \\
\text { a collection } \\
\text { of bills }\end{array}$ & Yes \\
\hline 75 & $\begin{array}{l}\text { MacLeod } \\
\text { v Ontario }\end{array}$ & $\begin{array}{l}22- \\
\text { Dec- } \\
15\end{array}$ & SCJ & $\begin{array}{l}\text { Respond } \\
\text { ing Party }\end{array}$ & $\begin{array}{l}2015 \\
\text { ONSC } \\
7240, \\
\text { [2015] OJ } \\
\text { No } 6047\end{array}$ & $\begin{array}{l}2015 \\
\text { ONSC } \\
8020, \\
\text { [2015] } \\
\text { OJ No } \\
6772\end{array}$ & $\begin{array}{l}\text { Granted } \\
\text { After } \\
\text { Notice }\end{array}$ & N/A & None & $\begin{array}{l}\text { 32 Days: } \\
\text { Nov 20, } \\
2015 \text { to } \\
\text { Dec 22, } \\
2015\end{array}$ & Myers & $\begin{array}{l}\text { Incomprehen } \\
\text { sible; request } \\
\text { for } \\
\text { exemption } \\
\text { from credit } \\
\text { check }\end{array}$ & Yes \\
\hline 76 & $\begin{array}{l}\text { MacLeod } \\
v \\
\text { Hanrahan } \\
\text { Youth } \\
\text { Services }\end{array}$ & $\begin{array}{l}22- \\
\text { Dec- } \\
15\end{array}$ & SCJ & $\begin{array}{l}\text { Respond } \\
\text { ing Party }\end{array}$ & $\begin{array}{l}2015 \\
\text { ONSC } \\
8018, \\
\text { [2015] OJ } \\
\text { No 6771 }\end{array}$ & $\mathrm{N} / \mathrm{A}$ & $\begin{array}{l}\text { Notice } \\
\text { Not } \\
\text { Ordered }\end{array}$ & N/A & Unclear & 0 Days & Myers & $\begin{array}{l}\text { Request to } \\
\text { dismiss } \\
\text { defendant's } \\
\text { motion (itself } \\
\text { frivolous and } \\
\text { vexatious) }\end{array}$ & Yes \\
\hline 77 & $\begin{array}{l}\text { Reyes } v \\
\text { Esbin }\end{array}$ & $\begin{array}{l}11- \\
\text { Jan-16 }\end{array}$ & $\mathrm{SCJ}$ & $\begin{array}{l}\text { Respond } \\
\text { ing Party }\end{array}$ & $\begin{array}{l}2015 \\
\text { ONSC } \\
6885, \\
{[2015] \text { OJ }} \\
\text { No } 6469\end{array}$ & $\begin{array}{l}2015 \\
\text { ONSC } \\
254, \\
{[2015]} \\
\text { OJ No } 97\end{array}$ & $\begin{array}{l}\text { Partially } \\
\text { Granted }\end{array}$ & N/A & $\begin{array}{l}\text { Unclear } \\
\text { (submis } \\
\text { sions } \\
\text { called } \\
\text { for) }\end{array}$ & $\begin{array}{l}63 \text { Days: } \\
\text { Nov } 9 \text {, } \\
2015 \text { to } \\
\text { Jan } 11 \text {, } \\
2016\end{array}$ & Myers & $\begin{array}{l}\text { Loss of } \\
\text { valuable } \\
\text { chattels after } \\
\text { eviction }\end{array}$ & Yes \\
\hline 78 & $\begin{array}{l}\text { Frickv } \\
\text { Frick }\end{array}$ & $\begin{array}{l}18- \\
\text { Feb- } \\
16\end{array}$ & SCJ & $\begin{array}{l}\text { Respond } \\
\text { ing Party }\end{array}$ & $\begin{array}{l}\text { N/A - } \\
\text { Formal } \\
\text { Motion } \\
\text { Brought }\end{array}$ & $\begin{array}{l}2016 \\
\text { ONSC } \\
359,78\end{array}$ & $\begin{array}{l}\text { Dismisse } \\
\text { d After } \\
\text { Appeal }\end{array}$ & $\begin{array}{l}\text { Allowed } \\
\text { in Part: } \\
2016 \\
\text { ONCA }\end{array}$ & Unclear & $\begin{array}{l}70 \text { Days: } \\
\text { Dec } 10, \\
2015 \text { to } \\
\text { Feb } 18,\end{array}$ & Ellies & $\begin{array}{l}\text { Family law } \\
\text { use }\end{array}$ & No \\
\hline
\end{tabular}




\begin{tabular}{|c|c|c|c|c|c|c|c|c|c|c|c|c|c|}
\hline & & & & & & $\begin{array}{l}\text { RFL } \\
\text { (7th) } 430\end{array}$ & & $\begin{array}{l}799,132 \\
\text { OR (3d) } \\
321\end{array}$ & & $\begin{array}{l}2016 \text { to } \\
\text { Oct } 31, \\
2016\end{array}$ & & & \\
\hline 79 & $\begin{array}{l}\text { Purcaru v } \\
\text { Vacaru }\end{array}$ & $\begin{array}{l}07- \\
\text { Mar- } \\
16\end{array}$ & SCJ & $\begin{array}{l}\text { Respond } \\
\text { ing Party }\end{array}$ & $\begin{array}{l}2016 \\
\text { ONSC } \\
1037, \\
{[2016] \text { OJ }} \\
\text { No } 726\end{array}$ & $\begin{array}{l}2016 \\
\text { ONSC } \\
1609,76 \\
\text { RFL } \\
\text { (7th) } 333\end{array}$ & $\begin{array}{l}\text { Dismisse } \\
\text { d After } \\
\text { Notice }\end{array}$ & N/A & Unclear & $\begin{array}{l}25 \text { Days: } \\
\text { Feb 10, } \\
2016 \text { to } \\
\text { March } 7, \\
2016\end{array}$ & Myers & $\begin{array}{l}\text { Family law } \\
\text { dispute }\end{array}$ & Yes \\
\hline 80 & $\begin{array}{l}\text { Dias } v \\
\text { Ontario } \\
\text { (Workpla } \\
\text { ce Safety } \\
\& \\
\text { Insurance } \\
\text { Board) }\end{array}$ & $\begin{array}{l}10- \\
\text { Mar- } \\
16\end{array}$ & SCJ & $\begin{array}{l}\text { Respond } \\
\text { ing Party }\end{array}$ & $\begin{array}{l}2016 \\
\text { ONSC } \\
980, \\
{[2016] \text { OJ }} \\
\text { No 671 }\end{array}$ & $\begin{array}{l}2016 \\
\text { ONSC } \\
1752 \\
{[2016]} \\
\text { OJ No } \\
2464\end{array}$ & $\begin{array}{l}\text { Granted } \\
\text { After } \\
\text { Notice }\end{array}$ & N/A & Unclear & $\begin{array}{l}\text { 30 Days: } \\
\text { Feb 8, } \\
2016 \text { to } \\
\text { March } \\
10,2016\end{array}$ & Myers & $\begin{array}{l}\text { Attempt to } \\
\text { re-litigate } \\
\text { WSIB }\end{array}$ & Yes \\
\hline 81 & $\begin{array}{l}\text { Leev v } \\
\text { Future } \\
\text { Bakery } \\
\text { ltd }\end{array}$ & $\begin{array}{l}10- \\
\text { Mar- } \\
16\end{array}$ & SCJ & Unclear & N/A & $\begin{array}{l}2016 \\
\text { ONSC } \\
1764, \\
{[2016]} \\
\text { OJ No } \\
1266\end{array}$ & $\begin{array}{l}\text { Granted } \\
\text { Without } \\
\text { Notice }\end{array}$ & N/A & Unclear & 0 Days & Myers & $\begin{array}{l}\text { Attempt to } \\
\text { re-litigate }\end{array}$ & $\begin{array}{l}\text { Uncl } \\
\text { ear }\end{array}$ \\
\hline 82 & $\begin{array}{l}\text { Ochnik v } \\
\text { Belusa }\end{array}$ & $\begin{array}{l}10- \\
\text { Mar- } \\
16\end{array}$ & SCJ & Unclear & N/A & $\begin{array}{l}2016 \\
\text { ONSC } \\
1767, \\
{[2016]} \\
\text { OJ No } \\
1302\end{array}$ & $\begin{array}{l}\text { Granted } \\
\text { - Notice } \\
\text { Unclear }\end{array}$ & N/A & Unclear & N/A & Myers & $\begin{array}{l}\text { Attempt to } \\
\text { re-litigate but } \\
\text { different } \\
\text { party }\end{array}$ & $\begin{array}{l}\text { Uncl } \\
\text { ear }\end{array}$ \\
\hline 83 & $\begin{array}{l}\text { Ochnik v } \\
\text { Belusa }\end{array}$ & $\begin{array}{l}10- \\
\text { Mar- } \\
16\end{array}$ & SCJ & Unclear & N/A & $\begin{array}{l}2016 \\
\text { ONSC } \\
1861 \\
{[2016]} \\
\text { OJ No } \\
1386\end{array}$ & $\begin{array}{l}\text { Granted } \\
\text { - Notice } \\
\text { Unclear }\end{array}$ & $\mathrm{N} / \mathrm{A}$ & Unclear & N/A & Myers & $\begin{array}{l}\text { Attempt to } \\
\text { re-litigate but } \\
\text { different } \\
\text { party }\end{array}$ & $\begin{array}{l}\text { Uncl } \\
\text { ear }\end{array}$ \\
\hline 84 & $\begin{array}{l}\text { Noddle v } \\
\text { Attorney } \\
\text { General } \\
\text { (Ontario) }\end{array}$ & $\begin{array}{l}14- \\
\text { Mar- } \\
16\end{array}$ & SCJ & $\begin{array}{l}\text { Respond } \\
\text { ing Party }\end{array}$ & $\begin{array}{l}2016 \\
\text { ONSC } \\
1826, \\
{[2016] \text { OJ }} \\
\text { No } 1317\end{array}$ & N/A & $\begin{array}{l}\text { Notice } \\
\text { Not } \\
\text { Ordered }\end{array}$ & $\mathrm{N} / \mathrm{A}$ & None & N/A & Myers & $\begin{array}{l}\text { Claim } \\
\text { Against } \\
\text { Gov’t for } \\
\text { Med Mal and } \\
\text { Incarceration }\end{array}$ & Yes \\
\hline 85 & $\begin{array}{l}\text { Rallis } v \\
\text { Scarboro } \\
\text { ugh } \\
\text { Hospital }\end{array}$ & $\begin{array}{l}04- \\
\text { Apr- } \\
16\end{array}$ & SCJ & Unclear & $\begin{array}{l}2016 \\
\text { ONSC } \\
1763, \\
{[2016] \text { OJ }} \\
\text { No } 1264\end{array}$ & $\begin{array}{l}2016 \\
\text { ONSC } \\
2263 \\
{[2016]} \\
\text { OJ No } \\
1773\end{array}$ & $\begin{array}{l}\text { Ordered } \\
\text { to Serve } \\
\text { Amende } \\
d \\
\text { Pleading }\end{array}$ & N/A & Unclear & $\begin{array}{l}\text { 25 Days: } \\
\text { March } \\
\text { 10, } 2016 \\
\text { to April } \\
\text { 4, } 2016\end{array}$ & Myers & $\begin{array}{l}\text { Medical } \\
\text { malpractice }\end{array}$ & Yes \\
\hline 86 & $\begin{array}{l}\text { Goralczyk } \\
\text { v Beer } \\
\text { Store }\end{array}$ & $\begin{array}{l}04- \\
\text { Apr- } \\
16\end{array}$ & SCJ & $\begin{array}{l}\text { Respond } \\
\text { ing Party }\end{array}$ & $\begin{array}{l}2016 \\
\text { ONSC } \\
993, \\
{[2016] \text { OJ }} \\
\text { No } 675\end{array}$ & $\begin{array}{l}\begin{array}{l}\text { Mostly } \\
\text { granted: }\end{array} \\
2016 \\
\text { ONSC } \\
2265, \\
{[2016]} \\
\text { OJ No } \\
1763 \text { and } \\
\text { entirely } \\
\text { granted: } \\
2016\end{array}$ & $\begin{array}{l}\text { Granted } \\
\text { After } \\
\text { Notice }\end{array}$ & N/A & $\begin{array}{l}\begin{array}{l}\text { None } \\
\text { (against }\end{array} \\
\text { some); } \\
\text { Unclear } \\
\text { (against } \\
\text { others) }\end{array}$ & $\begin{array}{l}\text { 55 Days: } \\
\text { Feb 8, } \\
2016 \text { to } \\
\text { April 4, } \\
2016 \text { to } \\
\text { July 5, } \\
2016 \\
\text { (More } \\
\text { time } \\
\text { granted } \\
\text { on }\end{array}$ & Myers & $\begin{array}{l}\text { Mostly } \\
\text { incomprehens } \\
\text { ible claim } \\
\text { including } \\
\text { slip-and-fall }\end{array}$ & Yes \\
\hline
\end{tabular}




\begin{tabular}{|c|c|c|c|c|c|c|c|c|c|c|c|c|c|}
\hline & & & & & & $\begin{array}{l}\text { ONSC } \\
4416, \\
{[2016]} \\
\text { OJ No } \\
3597\end{array}$ & & & & $\begin{array}{l}\text { March } 9 \\
\text { and May } \\
9: 2016 \\
\text { ONSC } \\
1699, \\
{[2016]} \\
\text { OJ No } \\
1196)\end{array}$ & & & \\
\hline 87 & $\begin{array}{l}\text { Nguyen v } \\
\text { Bail }\end{array}$ & $\begin{array}{l}04- \\
\text { Apr- } \\
16\end{array}$ & SCJ & $\begin{array}{l}\text { Respond } \\
\text { ing Party }\end{array}$ & $\begin{array}{l}2016 \\
\text { ONSC } \\
1828, \\
{[2016] \text { OJ }} \\
\text { No } 1316\end{array}$ & $\begin{array}{l}2016 \\
\text { ONSC } \\
2259, \\
{[2016]} \\
\text { OJ No } \\
1769\end{array}$ & $\begin{array}{l}\text { Granted } \\
\text { After } \\
\text { Notice }\end{array}$ & N/A & None & $\begin{array}{l}\text { 21 Days: } \\
\text { March } \\
14,2016 \\
\text { to April } \\
4,2016\end{array}$ & Myers & $\begin{array}{l}\text { Attempt to } \\
\text { re-litigate }\end{array}$ & Yes \\
\hline 88 & $\begin{array}{l}\text { Nguyen v } \\
\text { Economic } \\
\text { al Mutual } \\
\text { Insurance } \\
\text { Co }\end{array}$ & $\begin{array}{l}\text { 04- } \\
\text { Apr- } \\
16\end{array}$ & SCJ & Unclear & N/A & $\begin{array}{l}2016 \\
\text { ONSC } \\
2260, \\
2016 \\
\text { Carswell } \\
\text { Ont 5186 }\end{array}$ & $\begin{array}{l}\text { Granted } \\
\text { After } \\
\text { Notice }\end{array}$ & N/A & None & $\begin{array}{l}\text { 40 Days: } \\
\text { Feb 23, } \\
2016 \text { to } \\
\text { April 4, } \\
2016\end{array}$ & Myers & $\begin{array}{l}\text { Attempt to } \\
\text { re-litigate }\end{array}$ & Yes \\
\hline 89 & $\begin{array}{l}\text { Lin } v \\
\text { ICBC } \\
\text { Vancouve } \\
\text { r Head } \\
\text { Office }\end{array}$ & $\begin{array}{l}04- \\
\text { Apr- } \\
16\end{array}$ & SCJ & Unclear & N/A & $\begin{array}{l}2016 \\
\text { ONSC } \\
2262, \\
{[2016]} \\
\text { OJ No } \\
1766\end{array}$ & $\begin{array}{l}\text { Granted } \\
\text { After } \\
\text { Notice }\end{array}$ & $\begin{array}{l}\text { Affirme } \\
\text { d: } 2016 \\
\text { ONSC } \\
3934, \\
{[2016]} \\
\text { OJ No } \\
3223 \\
\text { (Div Ct), } \\
2016 \\
\text { ONCA } \\
788, \\
\text { [2016] } \\
\text { OJ 6071, } \\
\text { leave to } \\
\text { appeal } \\
\text { ref'd, } \\
2017 \\
\text { Carswell } \\
\text { Ont } 807 \\
\text { (SCC) }\end{array}$ & Unclear & $\begin{array}{l}\text { 25 Days: } \\
\text { March } \\
\text { 10, } 2016 \\
\text { to April } \\
4,2016 \\
\text { to Oct } \\
2016 \text { to } \\
\text { April 13, } \\
2017\end{array}$ & Myers & $\begin{array}{l}\text { Attempt to } \\
\text { re-litigate - } \\
\text { appeals } \\
\text { dismissed } \\
\text { under Rule } \\
2.1\end{array}$ & Yes \\
\hline 90 & $\begin{array}{l}\text { Nguyen v } \\
\text { Bail }\end{array}$ & $\begin{array}{l}\text { 07- } \\
\text { Apr- } \\
16\end{array}$ & SCJ & Unclear & N/A & $\begin{array}{l}2016 \\
\text { ONSC } \\
2365, \\
{[2016]} \\
\text { OJ No } \\
1840\end{array}$ & $\begin{array}{l}\text { Granted } \\
\text { Without } \\
\text { Notice }\end{array}$ & N/A & Unclear & 0 Days & Myers & $\begin{array}{l}\text { Attempt to } \\
\text { re-litigate }\end{array}$ & Yes \\
\hline 91 & $\begin{array}{l}\text { Leandre v } \\
\text { Windsor } \\
\text { Regional } \\
\text { Hospital }\end{array}$ & $\begin{array}{l}20- \\
\text { Apr- } \\
16\end{array}$ & SCJ & $\begin{array}{l}\text { Respond } \\
\text { ing Party }\end{array}$ & $\begin{array}{l}2016 \\
\text { ONSC } \\
2657, \\
{[2016] \text { OJ }} \\
\text { No } 2300\end{array}$ & N/A & $\begin{array}{l}\text { Notice } \\
\text { Ordered; } \\
\text { Unclear } \\
\text { Result }\end{array}$ & N/A & Unclear & N/A & Faieta & $\begin{array}{l}\text { Discriminatio } \\
\mathrm{n} / \text { failure to } \\
\text { honour } \\
\text { insurance }\end{array}$ & $\begin{array}{l}\text { Uncl } \\
\text { ear }\end{array}$ \\
\hline 92 & $\begin{array}{l}\text { Ramlallv } \\
\text { Jahir } \\
\text { Ullah } \\
\text { Pharmacy } \\
\text { Inc \#1333 }\end{array}$ & $\begin{array}{l}22- \\
\text { Apr- } \\
16\end{array}$ & SCJ & $\begin{array}{l}\text { Respond } \\
\text { ing Party }\end{array}$ & $\begin{array}{l}2016 \\
\text { ONSC } \\
2705, \\
{[2016] \text { OJ }} \\
\text { No } 2139\end{array}$ & N/A & $\begin{array}{l}\text { Notice } \\
\text { Not } \\
\text { Ordered }\end{array}$ & N/A & Unclear & N/A & Myers & $\begin{array}{l}\text { Failure to } \\
\text { honour sale } \\
\text { prices }\end{array}$ & Yes \\
\hline
\end{tabular}




\begin{tabular}{|c|c|c|c|c|c|c|c|c|c|c|c|c|c|}
\hline 93 & $\begin{array}{l}\text { Chalupni } \\
\text { cek v } \\
\text { Children' } \\
\text { s Aid } \\
\text { Society of } \\
\text { Ottawa }\end{array}$ & $\begin{array}{l}26- \\
\text { Apr- } \\
16\end{array}$ & SCJ & $\begin{array}{l}\text { Respond } \\
\text { ing Party }\end{array}$ & $\begin{array}{l}2016 \\
\text { ONSC } \\
2353, \\
{[2016] \text { OJ }} \\
\text { No } 1940\end{array}$ & $\begin{array}{l}2016 \\
\text { ONSC } \\
2787, \\
{[2016]} \\
\text { OJ No } \\
2122\end{array}$ & $\begin{array}{l}\text { Granted } \\
\text { After } \\
\text { Notice }\end{array}$ & 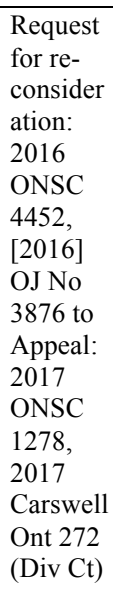 & $\begin{array}{l}\$ 17,684 \\
.83 \\
\text { (Appeal } \\
\text { - Full } \\
\text { Indemni } \\
\text { ty) }\end{array}$ & $\begin{array}{l}\text { 19 Days: } \\
\text { April 7, } \\
2016 \text { to } \\
\text { April 26, } \\
2016 \text { to } \\
\text { July 6, } \\
2016 \text { to } \\
\text { Feb 23, } \\
2017\end{array}$ & $\begin{array}{l}\text { MacLeo } \\
\mathrm{d}\end{array}$ & $\begin{array}{l}\text { Kidnapping } \\
\text { of children }\end{array}$ & No \\
\hline 94 & $\begin{array}{l}\text { Dias v } \\
\text { Ontario } \\
\text { (Liquor } \\
\text { Control } \\
\text { Board) }\end{array}$ & $\begin{array}{l}12- \\
\text { May- } \\
16\end{array}$ & SCJ & $\begin{array}{l}\text { Respond } \\
\text { ing Party }\end{array}$ & $\begin{array}{l}2016 \\
\text { ONSC } \\
2364, \\
{[2016] \text { OJ }} \\
\text { No } 1827\end{array}$ & $\begin{array}{l}2016 \\
\text { ONSC } \\
3135, \\
{[2016]} \\
\text { OJ No } \\
2465\end{array}$ & $\begin{array}{l}\text { Granted } \\
\text { After } \\
\text { Notice }\end{array}$ & N/A & Unclear & $\begin{array}{l}35 \text { Days: } \\
\text { April 7, } \\
2016 \text { to } \\
\text { May 12, } \\
2016\end{array}$ & Myers & $\begin{array}{l}\text { Attempt to } \\
\text { re-litigate }\end{array}$ & Yes \\
\hline 95 & $\begin{array}{l}\text { Murray v } \\
\text { Toronto } \\
\text { (City) }\end{array}$ & $\begin{array}{l}12- \\
\text { May- } \\
16\end{array}$ & SCJ & $\begin{array}{l}\text { Respond } \\
\text { ing Party }\end{array}$ & $\begin{array}{l}2016 \\
\text { ONSC } \\
2355, \\
{[2016] \text { OJ }} \\
1839\end{array}$ & $\begin{array}{l}2016 \\
\text { ONSC } \\
3137, \\
{[2016]} \\
\text { OJ No } \\
2472\end{array}$ & $\begin{array}{l}\text { Granted } \\
\text { After } \\
\text { Notice }\end{array}$ & N/A & Unclear & $\begin{array}{l}35 \text { Days: } \\
\text { April 7, } \\
2016 \text { to } \\
\text { May 12, } \\
2016\end{array}$ & Myers & $\begin{array}{l}\text { Seeks public } \\
\text { inquiry }\end{array}$ & Yes \\
\hline 96 & $\begin{array}{l}\text { Leandre v } \\
\text { Children' } \\
\text { s Aid } \\
\text { Society of } \\
\text { London }\end{array}$ & $\begin{array}{l}18- \\
\text { May- } \\
16\end{array}$ & SCJ & $\begin{array}{l}\text { Respond } \\
\text { ing Party }\end{array}$ & $\begin{array}{l}2016 \\
\text { ONSC } \\
2472, \\
{[2016] \text { OJ }} \\
\text { No } 1902\end{array}$ & $\begin{array}{l}2016 \\
\text { ONSC } \\
3250, \\
{[2016]} \\
\text { OJ No } \\
2959\end{array}$ & $\begin{array}{l}\text { Granted } \\
\text { After } \\
\text { Notice }\end{array}$ & N/A & Unclear & $\begin{array}{l}35 \text { Days: } \\
\text { April 13, } \\
2016 \text { to } \\
\text { May } 18, \\
2016\end{array}$ & $\begin{array}{l}\text { Diamon } \\
\mathrm{d}\end{array}$ & $\begin{array}{l}\text { Attempt to } \\
\text { re-litigate }\end{array}$ & Yes \\
\hline 97 & $\begin{array}{l}\text { Thompso } \\
n v W J \\
\text { Holdings } \\
\text { Ltd }\end{array}$ & $\begin{array}{l}31- \\
\text { May- } \\
16\end{array}$ & SCJ & $\begin{array}{l}\text { Respond } \\
\text { ing Party }\end{array}$ & $\begin{array}{l}2016 \\
\text { ONSC } \\
2704, \\
{[2016] \text { OJ }} \\
\text { No } 2145\end{array}$ & $\begin{array}{l}2016 \\
\text { ONSC } \\
3591, \\
{[2016]} \\
\text { OJ No } \\
2942\end{array}$ & $\begin{array}{l}\text { Granted } \\
\text { After } \\
\text { Notice }\end{array}$ & N/A & Unclear & $\begin{array}{l}\text { 39 Days: } \\
\text { April 22, } \\
2016 \text { to } \\
\text { May 31, } \\
2016\end{array}$ & Myers & $\begin{array}{l}\text { Attempt to } \\
\text { re-litigate }\end{array}$ & Yes \\
\hline 98 & $\begin{array}{l}\text { SC v } \\
\text { Children' } \\
\text { s Aid } \\
\text { Society }\end{array}$ & $\begin{array}{l}31- \\
\text { May- } \\
16\end{array}$ & SCJ & $\begin{array}{l}\text { Respond } \\
\text { ing Party }\end{array}$ & $\begin{array}{l}2016 \\
\text { ONSC } \\
3592, \\
{[2016] \text { OJ }} \\
\text { No } 2953\end{array}$ & N/A & $\begin{array}{l}\text { Notice } \\
\text { Not } \\
\text { Ordered }\end{array}$ & N/A & Unclear & N/A & Myers & $\begin{array}{l}\text { Claim against } \\
\text { CAS for bad } \\
\text { treatment }\end{array}$ & Yes \\
\hline 99 & $\begin{array}{l}\text { Chaloob } \\
\text { v Canada } \\
\text { (Attorney } \\
\text { General) }\end{array}$ & $\begin{array}{l}31- \\
\text { May- } \\
16\end{array}$ & SCJ & Unclear & N/A & $\begin{array}{l}2016 \\
\text { ONSC } \\
3569, \\
{[2016]} \\
\text { OJ No } \\
3002\end{array}$ & $\begin{array}{l}\text { Granted } \\
\text { After } \\
\text { Notice }\end{array}$ & N/A & Unclear & $\begin{array}{l}\text { 55 Days: } \\
\text { April 6, } \\
2016 \text { to } \\
\text { May } 31, \\
2016\end{array}$ & $\begin{array}{l}\text { Beaudoi } \\
\mathrm{n}\end{array}$ & Unclear & $\begin{array}{l}\text { Uncl } \\
\text { ear }\end{array}$ \\
\hline 100 & $\begin{array}{l}\text { Ochnikv } \\
\text { Belusa }\end{array}$ & $\begin{array}{l}31- \\
\text { May- } \\
16\end{array}$ & SCJ & Unclear & $\begin{array}{l}2016 \\
\text { ONSC } \\
1860\end{array}$ & $\begin{array}{l}2016 \\
\text { ONSC } \\
3589\end{array}$ & $\begin{array}{l}\text { Granted } \\
\text { After } \\
\text { Notice }\end{array}$ & N/A & Unclear & $\begin{array}{l}77 \text { Days: } \\
\text { March } \\
15,2016\end{array}$ & Myers & $\begin{array}{l}\text { Attempt to } \\
\text { re-litigate }\end{array}$ & Yes \\
\hline
\end{tabular}




\begin{tabular}{|c|c|c|c|c|c|c|c|c|c|c|c|c|c|}
\hline & & & & & $\begin{array}{l}\text { [2016] OJ } \\
\text { No } 1385\end{array}$ & $\begin{array}{l}\text { [2016] } \\
\text { OJ No } \\
2950\end{array}$ & & & & $\begin{array}{l}\text { to May } \\
31,2016\end{array}$ & & & \\
\hline 101 & $\begin{array}{l}\text { Leandre v } \\
\text { Collectio } \\
n \text { Services } \\
\text { of } \\
\text { Windsor } \\
\text { Ltd }\end{array}$ & $\begin{array}{l}01- \\
\text { Jun-16 }\end{array}$ & SCJ & Unclear & $\begin{array}{l}2016 \\
\text { ONSC } \\
2733, \\
{[2016] \text { OJ }} \\
\text { No } 2125\end{array}$ & $\begin{array}{l}2016 \\
\text { ONSC } \\
2733, \\
{[2016]} \\
\text { OJ No } \\
2931\end{array}$ & $\begin{array}{l}\text { Granted } \\
\text { After } \\
\text { Notice }\end{array}$ & N/A & None & $\begin{array}{l}\text { 37 Days: } \\
\text { April 25, } \\
2016 \text { to } \\
\text { June 1, } \\
2016\end{array}$ & $\begin{array}{l}\text { Diamon } \\
\text { d }\end{array}$ & $\begin{array}{l}\text { Motion to } \\
\text { seek } \\
\text { immediate } \\
\text { arrest of } \\
\text { many } \\
\text { individuals }\end{array}$ & Yes \\
\hline 102 & $\begin{array}{l}\text { TFB v } \\
\text { Office of } \\
\text { the } \\
\text { Children' } \\
\text { s Lawyer }\end{array}$ & $\begin{array}{l}07- \\
\text { Jun-16 }\end{array}$ & SCJ & Unclear & N/A & $\begin{array}{l}2016 \\
\text { ONSC } \\
3816, \\
{[2016]} \\
\text { OJ No } \\
3024\end{array}$ & $\begin{array}{l}\text { Granted } \\
\text { After } \\
\text { Notice }\end{array}$ & N/A & Unclear & $\begin{array}{l}\text { 77 Days: } \\
\text { March } \\
22,2016 \\
\text { to June } \\
7,2016\end{array}$ & Trimble & $\begin{array}{l}\text { Claims } \\
\text { against } \\
\text { children's } \\
\text { lawyer not } \\
\text { actionable }\end{array}$ & Yes \\
\hline 103 & $\begin{array}{l}\text { Mitchell v } \\
\text { Ontario } \\
\text { (Ministry } \\
\text { of } \\
\text { Transport } \\
\text { ation) }\end{array}$ & $\begin{array}{l}16- \\
\text { Jun-16 }\end{array}$ & SCJ & Unclear & N/A & $\begin{array}{l}2016 \\
\text { ONSC } \\
4016, \\
{[2016]} \\
\text { OJ No } \\
3643\end{array}$ & $\begin{array}{l}\text { Granted } \\
\text { After } \\
\text { Notice }\end{array}$ & N/A & Unclear & $\begin{array}{l}118 \\
\text { Days: } \\
\text { Feb 18, } \\
2016 \text { to } \\
\text { June 16, } \\
2016\end{array}$ & Daley & $\begin{array}{l}\text { Obviously } \\
\text { meritless } \\
\text { appeal } \\
\text { brought in } \\
\text { wrong court }\end{array}$ & $\begin{array}{l}\text { Uncl } \\
\text { ear }\end{array}$ \\
\hline 104 & $\begin{array}{l}\text { Marleau } \\
v \\
\text { Brockville } \\
\text { (City) }\end{array}$ & $\begin{array}{l}30- \\
\text { Jun-16 }\end{array}$ & SCJ & $\begin{array}{l}\text { Respond } \\
\text { ing Party }\end{array}$ & N/A & $\begin{array}{l}2016 \\
\text { ONSC } \\
4364, \\
{[2016]} \\
\text { OJ No } \\
3634\end{array}$ & $\begin{array}{l}\text { Granted } \\
\text { After } \\
\text { Notice }\end{array}$ & N/A & $\begin{array}{l}5500: \\
2016 \\
\text { ONSC } \\
5901, \\
{[2016]} \\
\text { OJ No } \\
4961\end{array}$ & Unclear & $\begin{array}{l}\text { Trousda } \\
\text { le }\end{array}$ & $\begin{array}{l}\text { Statutory } \\
\text { Abuse of } \\
\text { Power, etc }\end{array}$ & Yes \\
\hline 105 & $\begin{array}{l}\text { Jarvis v } \\
\text { Morlog }\end{array}$ & $\begin{array}{l}07- \\
\text { Jul-16 }\end{array}$ & SCJ & $\begin{array}{l}\text { Respond } \\
\text { ing Party }\end{array}$ & $\begin{array}{l}2016 \\
\text { ONSC } \\
1827, \\
{[2016] \text { OJ }} \\
\text { No } 1314\end{array}$ & $\begin{array}{l}2016 \\
\text { ONSC } \\
4476, \\
{[2016]} \\
\text { OJ No } \\
3662\end{array}$ & $\begin{array}{l}\text { Granted } \\
\text { After } \\
\text { Notice }\end{array}$ & N/A & $\begin{array}{l}\$ 2,256 . \\
39: \\
2015 \\
\text { ONSC } \\
5061 \text {, } \\
2016 \\
\text { Carswel } \\
\text { lOnt } \\
12693 \\
\text { (substan } \\
\text { tial) }\end{array}$ & $\begin{array}{l}115 \\
\text { Days: } \\
\text { March } \\
14,2016 \\
\text { to July } 7 \text {, } \\
2016\end{array}$ & Myers & $\begin{array}{l}\text { Freeman on } \\
\text { the land re } \\
\text { criminal } \\
\text { court } \\
\text { summons }\end{array}$ & Yes \\
\hline 106 & $\begin{array}{l}\text { Irmya } v \\
\text { Mijovick }\end{array}$ & $\begin{array}{l}15- \\
\text { Jul-16 }\end{array}$ & SCJ & $\begin{array}{l}\text { Respond } \\
\text { ing Party }\end{array}$ & $\begin{array}{l}2016 \\
\text { ONSC } \\
3608, \\
{[2016] \text { OJ }} \\
\text { No 2935 }\end{array}$ & $\begin{array}{l}2016 \\
\text { ONSC } \\
4629, \\
{[2016]} \\
\text { OJ No } \\
3797\end{array}$ & $\begin{array}{l}\text { Granted } \\
\text { After } \\
\text { Notice }\end{array}$ & N/A & $\begin{array}{l}\$ 13,615 \\
.94, \\
\$ 6706.6 \\
5, \\
\$ 9,865 . \\
19 \text { (full } \\
\text { indemni } \\
\text { ty): } \\
2016 \\
\text { ONSC } \\
5276, \\
{[2016]} \\
\text { OJ No } \\
4372\end{array}$ & $\begin{array}{l}\text { 45 Days: } \\
\text { May } 31, \\
2016 \text { to } \\
\text { July } 15 \text {, } \\
2016\end{array}$ & Myers & $\begin{array}{l}\text { Condo } \\
\text { dispute }\end{array}$ & Yes \\
\hline 107 & $\begin{array}{l}\text { Asgharv } \\
\text { Toronto } \\
\text { (City) }\end{array}$ & $\begin{array}{l}27- \\
\text { Jul-16 }\end{array}$ & SCJ & $\begin{array}{l}\text { Respond } \\
\text { ing Party }\end{array}$ & $\begin{array}{l}2016 \\
\text { ONSC } \\
4844\end{array}$ & N/A & $\begin{array}{l}\text { Notice } \\
\text { Ordered; }\end{array}$ & N/A & Unclear & N/A & Faieta & Unclear & $\begin{array}{l}\text { Uncl } \\
\text { ear }\end{array}$ \\
\hline
\end{tabular}




\begin{tabular}{|c|c|c|c|c|c|c|c|c|c|c|c|c|c|}
\hline & $\begin{array}{l}\text { Police } \\
\text { Services } \\
\text { Board }\end{array}$ & & & & $\begin{array}{l}\text { [2016] OJ } \\
\text { No } 4028\end{array}$ & & $\begin{array}{l}\text { Unclear } \\
\text { Result }\end{array}$ & & & & & & \\
\hline 108 & $\begin{array}{l}\text { Parkv } \\
\text { Crossgate } \\
\text { Legal } \\
\text { Services }\end{array}$ & $\begin{array}{l}28- \\
\text { Jul-16 }\end{array}$ & SCJ & Registrar & N/A & $\begin{array}{l}2016 \\
\text { ONSC } \\
4864, \\
{[2016]} \\
\text { OJ No } \\
4021\end{array}$ & $\begin{array}{l}\text { Granted } \\
\text { Without } \\
\text { Notice }\end{array}$ & N/A & Unclear & 0 Days & Myers & $\begin{array}{l}\text { Commenced } \\
\text { in violation } \\
\text { of vexatious } \\
\text { litigant order }\end{array}$ & $\begin{array}{l}\text { Uncl } \\
\text { ear }\end{array}$ \\
\hline 109 & $\begin{array}{l}\text { Noddle v } \\
\text { Canada } \\
\text { (Deputy } \\
\text { Attorney } \\
\text { General) }\end{array}$ & $\begin{array}{l}28- \\
\text { Jul-16 }\end{array}$ & SCJ & $\begin{array}{l}\text { Respond } \\
\text { ing Party }\end{array}$ & $\begin{array}{l}2016 \\
\text { ONSC } \\
4866, \\
{[2016] \text { OJ }} \\
\text { No 4038 }\end{array}$ & N/A & $\begin{array}{l}\text { Notice } \\
\text { Ordered; } \\
\text { Unclear } \\
\text { Result }\end{array}$ & N/A & Unclear & N/A & Faeita & $\begin{array}{l}\text { Suit alleging } \\
\text { defamation } \\
\text { based on } \\
\text { contents of } \\
\text { past } \\
\text { pleadings }\end{array}$ & $\begin{array}{l}\text { Uncl } \\
\text { ear }\end{array}$ \\
\hline 110 & $\begin{array}{l}\text { Polanski } \\
v \text { Scharfe }\end{array}$ & $\begin{array}{l}29- \\
\text { Jul-16 }\end{array}$ & $\mathrm{SCJ}$ & $\begin{array}{l}\text { Respond } \\
\text { ing Party }\end{array}$ & $\begin{array}{l}2016 \\
\text { ONSC } \\
4892, \\
{[2016] \text { OJ }} \\
\text { No 4039 }\end{array}$ & $\mathrm{N} / \mathrm{A}$ & $\begin{array}{l}\text { Notice } \\
\text { Not } \\
\text { Ordered }\end{array}$ & N/A & Unclear & $\mathrm{N} / \mathrm{A}$ & Myers & $\begin{array}{l}\text { Strange claim } \\
\text { based on } \\
\text { dismissal } \\
\text { from articling }\end{array}$ & $\begin{array}{l}\text { Uncl } \\
\text { ear }\end{array}$ \\
\hline 111 & $\begin{array}{l}\text { D'Orazio } \\
\text { v Ontario } \\
\text { (Attorney } \\
\text { General) }\end{array}$ & $\begin{array}{l}29- \\
\text { Jul-16 }\end{array}$ & $\mathrm{SCJ}$ & $\begin{array}{l}\text { Respond } \\
\text { ing Party }\end{array}$ & N/A & $\begin{array}{l}2016 \\
\text { ONSC } \\
4893 \\
{[2016]} \\
\text { OJ No } \\
4031\end{array}$ & $\begin{array}{l}\text { Granted } \\
\text { Without } \\
\text { Notice }\end{array}$ & N/A & $\begin{array}{l}\text { Unclear } \\
\text { (partial) }\end{array}$ & 0 Days & Myers & $\begin{array}{l}\text { Acknowledge } \\
\text { d attempt to } \\
\text { re-litigate }\end{array}$ & Yes \\
\hline 112 & $\begin{array}{l}\text { Mester v } \\
\text { Weh }\end{array}$ & $\begin{array}{l}29- \\
\text { Jul-16 }\end{array}$ & SCJ & $\begin{array}{l}\text { Respond } \\
\text { ing Party }\end{array}$ & $\begin{array}{l}\text { Dec } 17, \\
2015 \text { (not } \\
\text { reported - } \\
\text { by } \\
\text { registrar) }\end{array}$ & $\begin{array}{l}2016 \\
\text { ONSC } \\
4887, \\
{[2016]} \\
\text { OJ No } \\
4274\end{array}$ & $\begin{array}{l}\text { Dismisse } \\
\text { d After } \\
\text { Notice }\end{array}$ & N/A & None & $\begin{array}{l}252 \\
\text { Days: } \\
\text { Nov 19, } \\
2015 \text { to } \\
\text { July 29, } \\
2016\end{array}$ & $\begin{array}{l}\text { Maddale } \\
\text { na }\end{array}$ & $\begin{array}{l}\text { Serious } \\
\text { allegations } \\
\text { but detailed }\end{array}$ & $\begin{array}{l}\text { Uncl } \\
\text { ear }\end{array}$ \\
\hline 113 & $\begin{array}{l}\text { Musole v } \\
\text { Buset \& } \\
\text { Partners } \\
\text { LLP }\end{array}$ & $\begin{array}{l}02- \\
\text { Aug- } \\
16\end{array}$ & SCJ & $\begin{array}{l}\text { Respond } \\
\text { ing Party }\end{array}$ & $\begin{array}{l}2016 \\
\text { ONSC } \\
4429, \\
{[2016] \text { OJ }} \\
\text { No } 3886\end{array}$ & $\begin{array}{l}2016 \\
\text { ONSC } \\
5561, \\
{[2016]} \\
\text { OJ No } \\
4699\end{array}$ & $\begin{array}{l}\text { Granted } \\
\text { After } \\
\text { Notice }\end{array}$ & N/A & None & $\begin{array}{l}63 \text { Days: } \\
\text { July } 5 \text {, } \\
2016 \text { to } \\
\text { Sept } 6 \text {, } \\
2016\end{array}$ & $\begin{array}{l}\text { Beaudoi } \\
\mathrm{n}\end{array}$ & $\begin{array}{l}\text { Attempt to } \\
\text { re-litigate }\end{array}$ & Yes \\
\hline 114 & $\begin{array}{l}\text { Carby- } \\
\text { Samuels } v \\
\text { Carby- } \\
\text { Samuels }\end{array}$ & $\begin{array}{l}05- \\
\text { Aug- } \\
16\end{array}$ & $\mathrm{SCJ}$ & $\begin{array}{l}\text { Respond } \\
\text { ing Party }\end{array}$ & $\begin{array}{l}2016 \\
\text { ONSC } \\
4974, \\
{[2016] \text { OJ }} \\
\text { No 4188 }\end{array}$ & N/A & $\begin{array}{l}\text { Notice } \\
\text { Not } \\
\text { Ordered }\end{array}$ & N/A & Unclear & N/A & $\begin{array}{l}\text { Beaudoi } \\
\mathrm{n}\end{array}$ & $\begin{array}{l}\text { Muddled but } \\
\text { discernible } \\
\text { claim }\end{array}$ & $\begin{array}{l}\text { Uncl } \\
\text { ear }\end{array}$ \\
\hline 115 & $\begin{array}{l}\text { Graff v } \\
\text { Network } \\
\text { North } \\
\text { Reporting } \\
\text { and } \\
\text { Mediation }\end{array}$ & $\begin{array}{l}15- \\
\text { Aug- } \\
16\end{array}$ & $\overline{\mathrm{SCJ}}$ & $\begin{array}{l}\text { Respond } \\
\text { ing Party }\end{array}$ & $\begin{array}{l}2016 \\
\text { ONSC } \\
5158, \\
{[2016] \text { OJ }} \\
\text { No 4301 }\end{array}$ & N/A & $\begin{array}{l}\text { Notice } \\
\text { Not } \\
\text { Ordered }\end{array}$ & N/A & Unclear & N/A & Myers & $\begin{array}{l}\text { Claim against } \\
\text { former } \\
\text { medical } \\
\text { experts }\end{array}$ & $\begin{array}{l}\text { Uncl } \\
\text { ear }\end{array}$ \\
\hline 116 & $\begin{array}{l}\text { MacLeod } \\
\text { (Litigatio } \\
n \\
\text { guardian } \\
\text { of) } v \\
\end{array}$ & $\begin{array}{l}19- \\
\text { Aug- } \\
16\end{array}$ & $\mathrm{SCJ}$ & Unclear & $\begin{array}{l}2016 \\
\text { ONSC } \\
5231, \\
{[2016] \text { OJ }} \\
\text { No 4342 } \\
\end{array}$ & $\begin{array}{l}2016 \\
\text { ONSC } \\
5845, \\
{[2016]}\end{array}$ & $\begin{array}{l}\text { Granted } \\
\text { After } \\
\text { Notice }\end{array}$ & N/A & Unclear & $\begin{array}{l}33 \text { Days: } \\
\text { Aug } 17 \text {, } \\
2016 \text { to } \\
\text { Sept } 19 \text {, } \\
2016\end{array}$ & Myers & $\begin{array}{l}\text { Attempt to } \\
\text { litigate } \\
\text { prerogative } \\
\text { of family } \\
\text { courts }\end{array}$ & Yes \\
\hline
\end{tabular}




\begin{tabular}{|c|c|c|c|c|c|c|c|c|c|c|c|c|c|}
\hline & $\begin{array}{l}\text { Hanrahan } \\
\text { Youth } \\
\text { Services }\end{array}$ & & & & & $\begin{array}{l}\text { OJ No } \\
4814\end{array}$ & & & & & & & \\
\hline 117 & $\begin{array}{l}\text { Lochner } v \\
\text { Toronto } \\
\text { (City) } \\
\text { Police } \\
\text { Service }\end{array}$ & $\begin{array}{l}26- \\
\text { Aug- } \\
16\end{array}$ & SCJ & $\begin{array}{l}\text { Respond } \\
\text { ing Party }\end{array}$ & $\begin{array}{l}2016 \\
\text { ONSC } \\
5384, \\
{[2016] \text { OJ }} \\
\text { No } 4534\end{array}$ & N/A & $\begin{array}{l}\text { Notice } \\
\text { Ordered; } \\
\text { Unclear } \\
\text { Result }\end{array}$ & N/A & Unclear & N/A & $\begin{array}{l}\text { Goldstei } \\
\mathrm{n}\end{array}$ & $\begin{array}{l}\text { Motion was } \\
2.1 \text { ed after } \\
\text { determination } \\
\text { on other } \\
\text { issues } \\
\text { appears to } \\
\text { have } \\
\text { rendered } \\
\text { moot }\end{array}$ & Yes \\
\hline 118 & $\begin{array}{l}\text { Zhang } v \\
\text { Oh }\end{array}$ & $\begin{array}{l}31- \\
\text { Aug- } \\
16\end{array}$ & SCJ & $\begin{array}{l}\text { Respond } \\
\text { ing Party }\end{array}$ & $\begin{array}{l}2016 \\
\text { ONSC } \\
3734, \\
{[2016] \text { OJ }} \\
\text { No } 3021\end{array}$ & $\begin{array}{l}2016 \\
\text { ONSC } \\
5484, \\
{[2016]} \\
\text { OJ No } \\
4710\end{array}$ & $\begin{array}{l}\text { Granted } \\
\text { After } \\
\text { Notice }\end{array}$ & N/A & Unclear & $\begin{array}{l}\text { 86 Days: } \\
\text { June 6, } \\
2016 \text { to } \\
\text { Aug } 31 \text {, } \\
2016\end{array}$ & $\begin{array}{l}\text { Beaudoi } \\
\mathrm{n}\end{array}$ & $\begin{array}{l}\text { Suit of } \\
\text { senator for } \\
\text { being spy }\end{array}$ & Yes \\
\hline 119 & $\begin{array}{l}\text { Reyes } v \\
\text { Buhler }\end{array}$ & $\begin{array}{l}06- \\
\text { Sep- } \\
16\end{array}$ & SCJ & Unclear & N/A & $\begin{array}{l}2016 \\
\text { ONSC } \\
5559, \\
{[2016]} \\
\text { OJ No } \\
4635\end{array}$ & $\begin{array}{l}\text { Granted } \\
\text { Without } \\
\text { Notice }\end{array}$ & N/A & $\begin{array}{l}\text { Unclear } \\
\text { (Full) }\end{array}$ & N/A & Myers & $\begin{array}{l}\text { Commenced } \\
\text { in violation } \\
\text { of vexatious } \\
\text { litigant order }\end{array}$ & $\begin{array}{l}\text { Uncl } \\
\text { ear }\end{array}$ \\
\hline 120 & $\begin{array}{l}\text { Reyes } v \\
\text { Jocelyn }\end{array}$ & $\begin{array}{l}06- \\
\text { Sep- } \\
16\end{array}$ & SCJ & Unclear & N/A & $\begin{array}{l}2016 \\
\text { ONSC } \\
5568, \\
{[2016]} \\
\text { OJ No } \\
4642\end{array}$ & $\begin{array}{l}\text { Granted } \\
\text { Without } \\
\text { Notice }\end{array}$ & N/A & $\begin{array}{l}\text { Unclear } \\
\text { (Full) }\end{array}$ & N/A & Myers & $\begin{array}{l}\text { Commenced } \\
\text { in violation } \\
\text { of vexatious } \\
\text { litigant order }\end{array}$ & $\begin{array}{l}\text { Uncl } \\
\text { ear }\end{array}$ \\
\hline 121 & $\begin{array}{l}\text { Reyes } v \\
\text { Embry }\end{array}$ & $\begin{array}{l}06- \\
\text { Sep- } \\
16\end{array}$ & SCJ & Unclear & N/A & $\begin{array}{l}2016 \\
\text { ONSC } \\
5558, \\
{[2016]} \\
\text { OJ No } \\
4636\end{array}$ & $\begin{array}{l}\text { Granted } \\
\text { Without } \\
\text { Notice }\end{array}$ & N/A & $\begin{array}{l}\text { Unclear } \\
\text { (Full) }\end{array}$ & N/A & Myers & $\begin{array}{l}\text { Commenced } \\
\text { in violation } \\
\text { of vexatious } \\
\text { litigant order }\end{array}$ & $\begin{array}{l}\text { Uncl } \\
\text { ear }\end{array}$ \\
\hline 122 & $\begin{array}{l}\text { Dias v } \\
\text { Ontario } \\
\text { (Workpla } \\
\text { ce Safety } \\
\& \\
\text { Insurance } \\
\text { Board) }\end{array}$ & $\begin{array}{l}\text { 09- } \\
\text { Sep- } \\
16\end{array}$ & SCJ & $\begin{array}{l}\text { Respond } \\
\text { ing Party }\end{array}$ & $\begin{array}{l}2016 \\
\text { ONSC } \\
5226, \\
{[2016] \text { OJ }} \\
\text { No } 4355\end{array}$ & $\begin{array}{l}2016 \\
\text { ONSC } \\
5636, \\
{[2016]} \\
\text { OJ No } \\
4662\end{array}$ & $\begin{array}{l}\text { Granted } \\
\text { After } \\
\text { Notice }\end{array}$ & N/A & Unclear & $\begin{array}{l}23 \text { Days: } \\
\text { Aug 17, } \\
2016 \text { to } \\
\text { Sept } 9 \text {, } \\
2016\end{array}$ & Braid & $\begin{array}{l}\text { Attempt to } \\
\text { re-litigate } \\
\text { Toronto } \\
\text { actions }\end{array}$ & Yes \\
\hline 123 & $\begin{array}{l}\text { Sagos v } \\
\text { Edelson }\end{array}$ & $\begin{array}{l}23- \\
\text { Sep- } \\
16\end{array}$ & SCJ & $\begin{array}{l}\text { Respond } \\
\text { ing Party }\end{array}$ & $\begin{array}{l}2016 \\
\text { ONSC } \\
4482, \\
{[2016] \text { OJ }} \\
\text { No } 3894\end{array}$ & $\begin{array}{l}2016 \\
\text { ONSC } \\
5987, \\
{[2016]} \\
\text { OJ No } \\
4936\end{array}$ & $\begin{array}{l}\text { Granted } \\
\text { After } \\
\text { Notice }\end{array}$ & N/A & Unclear & $\begin{array}{l}78 \text { Days: } \\
\text { July } 7 \text {, } \\
2016 \text { to } \\
\text { Sept } 23 \text {, } \\
2016\end{array}$ & $\begin{array}{l}\text { Beaudoi } \\
\mathrm{n}\end{array}$ & $\begin{array}{l}\text { Statute- } \\
\text { barred, likely } \\
\text { jurisdiction- } \\
\text { barred, } \\
\text { unclear claim } \\
\text { against } \\
\text { lawyer }\end{array}$ & Yes \\
\hline 124 & $\begin{array}{l}\text { Bisumbul } \\
e v \\
\text { Conway }\end{array}$ & $\begin{array}{l}30- \\
\text { Sep- } \\
16\end{array}$ & SCJ & $\begin{array}{l}\text { Respond } \\
\text { ing Party }\end{array}$ & $\begin{array}{l}2016 \\
\text { ONSC } \\
6138, \\
{[2016] \text { OJ }} \\
\text { No } 5209\end{array}$ & N/A & $\begin{array}{l}\text { Notice } \\
\text { Not } \\
\text { Ordered }\end{array}$ & N/A & Unclear & N/A & $\begin{array}{l}\text { Beaudoi } \\
\mathrm{n}\end{array}$ & $\begin{array}{l}\text { Arguable res } \\
\text { judicata/limit } \\
\text { ations period }\end{array}$ & $\begin{array}{l}\text { Uncl } \\
\text { ear }\end{array}$ \\
\hline
\end{tabular}




\begin{tabular}{|c|c|c|c|c|c|c|c|c|c|c|c|c|c|}
\hline 125 & $\begin{array}{l}\text { Troncana } \\
d a \& \\
\text { Associate } \\
s v \\
\text { B2Gold } \\
\text { Corp }\end{array}$ & $\begin{array}{l}06- \\
\text { Oct-16 }\end{array}$ & $\mathrm{SCJ}$ & $\begin{array}{l}\text { Respond } \\
\text { ing Party }\end{array}$ & $\begin{array}{l}2016 \\
\text { ONSC } \\
6271, \\
{[2016] \text { OJ }} \\
\text { No } 5190\end{array}$ & N/A & $\begin{array}{l}\text { Notice } \\
\text { Not } \\
\text { Ordered }\end{array}$ & N/A & Unclear & N/A & Dow & $\begin{array}{l}\text { Arguable } \\
\text { attempt to re- } \\
\text { litigate }\end{array}$ & $\begin{array}{l}\text { Uncl } \\
\text { ear }\end{array}$ \\
\hline 126 & $\begin{array}{l}\text { M.S. } v \\
\text { Elia } \\
\text { Associate } \\
\text { s } \\
\text { Professio } \\
\text { nal Corp }\end{array}$ & $\begin{array}{l}26- \\
\text { Oct-16 }\end{array}$ & SCJ & $\begin{array}{l}\text { Respond } \\
\text { ing Party }\end{array}$ & $\begin{array}{l}2016 \\
\text { ONSC } \\
5375, \\
{[2016] \text { OJ }} \\
\text { No } 4479\end{array}$ & $\begin{array}{l}2016 \\
\text { ONSC } \\
6714, \\
{[2016]} \\
\text { OJ No } \\
5628\end{array}$ & $\begin{array}{l}\text { Granted } \\
\text { After } \\
\text { Notice }\end{array}$ & N/A & Unclear & $\begin{array}{l}\text { 62 Days: } \\
\text { Aug 25, } \\
2016 \text { to } \\
\text { Oct } 26 \text {, } \\
2016\end{array}$ & $\begin{array}{l}\text { Beaudoi } \\
\mathrm{n}\end{array}$ & $\begin{array}{l}\text { Attempt to } \\
\text { re-litigate }\end{array}$ & Yes \\
\hline 127 & $\begin{array}{l}\text { Sagos v } \\
\text { Bermuda } \\
\text { (Attorney } \\
\text { General) }\end{array}$ & $\begin{array}{l}01- \\
\text { Nov- } \\
16\end{array}$ & $\mathrm{SCJ}$ & $\begin{array}{l}\text { Respond } \\
\text { ing Party }\end{array}$ & $\begin{array}{l}2016 \\
\text { ONSC } \\
5664, \\
{[2016] \text { OJ }} \\
\text { No } 4709\end{array}$ & $\begin{array}{l}2016 \\
\text { ONSC } \\
6806, \\
2016 \\
\text { Carswell } \\
\text { Ont } \\
17293\end{array}$ & $\begin{array}{l}\text { Granted } \\
\text { After } \\
\text { Notice }\end{array}$ & N/A & Unclear & $\begin{array}{l}\text { 52 Days: } \\
\text { Sept 12, } \\
2016 \text { to } \\
\text { Nov 1, } \\
2016\end{array}$ & $\begin{array}{l}\text { Beaudoi } \\
\mathrm{n}\end{array}$ & $\begin{array}{l}\text { Attempt to } \\
\text { sue } \\
\text { Bermudan } \\
\text { police in } \\
\text { Ontario }\end{array}$ & Yes \\
\hline 128 & $\begin{array}{l}\text { Chapadea } \\
u v \\
\text { Addelman }\end{array}$ & $\begin{array}{l}01- \\
\text { Nov- } \\
16\end{array}$ & $\mathrm{SCJ}$ & $\begin{array}{l}\text { Respond } \\
\text { ing Party }\end{array}$ & $\begin{array}{l}2016 \\
\text { ONSC } \\
6803, \\
{[2016] \text { OJ }} \\
\text { No } 5655\end{array}$ & $\mathrm{~N} / \mathrm{A}$ & $\begin{array}{l}\text { Notice } \\
\text { Not } \\
\text { Ordered }\end{array}$ & N/A & None & $\mathrm{N} / \mathrm{A}$ & $\begin{array}{l}\text { Beaudoi } \\
\mathrm{n}\end{array}$ & $\begin{array}{l}\text { "Arguable } \\
\text { issues" }\end{array}$ & $\begin{array}{l}\text { Uncl } \\
\text { ear }\end{array}$ \\
\hline 129 & $\begin{array}{l}\text { Bouragba } \\
\text { v Conseil } \\
\text { des } \\
\text { Écoles } \\
\text { Publiques } \\
\text { de l'Est } \\
\text { de } \\
\text { l'Ontario }\end{array}$ & $\begin{array}{l}01- \\
\text { Nov- } \\
16\end{array}$ & $\mathrm{SCJ}$ & $\begin{array}{l}\text { Respond } \\
\text { ing Party }\end{array}$ & $\begin{array}{l}2016 \\
\text { ONSC } \\
6810, \\
{[2016] \text { OJ }} \\
\text { No } 5652\end{array}$ & $\mathrm{~N} / \mathrm{A}$ & $\begin{array}{l}\text { Notice } \\
\text { Ordered; } \\
\text { Unclear } \\
\text { Result }\end{array}$ & N/A & Unclear & N/A & $\begin{array}{l}\text { Beaudoi } \\
\mathrm{n}\end{array}$ & $\begin{array}{l}\text { Claims } \\
\text { arising from } \\
\text { suspension } \\
\text { from school }\end{array}$ & Yes \\
\hline 130 & $\begin{array}{l}\text { Zeleny v } \\
\text { Canada }\end{array}$ & $\begin{array}{l}18- \\
\text { Nov- } \\
16\end{array}$ & SCJ & $\begin{array}{l}\text { Respond } \\
\text { ing Party }\end{array}$ & N/A & $\begin{array}{l}2016 \\
\text { ONSC } \\
7226, \\
{[2016]} \\
\text { OJ No } \\
6101\end{array}$ & $\begin{array}{l}\text { Granted } \\
\text { After } \\
\text { Notice }\end{array}$ & N/A & None & N/A & $\begin{array}{l}\text { Minnem } \\
\text { a }\end{array}$ & $\begin{array}{l}\text { Sought half- } \\
\text { billion dollars } \\
\text { as per } \\
\text { obviously } \\
\text { fake bonds }\end{array}$ & Yes \\
\hline 131 & $\begin{array}{l}\text { Clarkv } \\
\text { Sports } \\
\text { Cafe } \\
\text { Champio } \\
\text { ns }\end{array}$ & $\begin{array}{l}21- \\
\text { Nov- } \\
16\end{array}$ & $\mathrm{SCJ}$ & $\begin{array}{l}\text { Respond } \\
\text { ing Party }\end{array}$ & $\begin{array}{l}2016 \\
\text { ONSC } \\
7303, \\
{[2016] \text { OJ }} \\
\text { No } 5991\end{array}$ & $\begin{array}{l}2016 \\
\text { ONSC } \\
8046, \\
{[2016]} \\
\text { OJ No } \\
6605\end{array}$ & $\begin{array}{l}\text { Granted } \\
\text { After } \\
\text { Notice }\end{array}$ & N/A & None & $\begin{array}{l}28 \text { Days: } \\
\text { Nov 23, } \\
2016 \text { to } \\
\text { Dec } 21, \\
2016\end{array}$ & Myers & $\begin{array}{l}\text { Wrong } \\
\text { forum, no } \\
\text { standing }\end{array}$ & Yes \\
\hline 132 & $\begin{array}{l}\text { Beseiso v } \\
\text { Halton } \\
\text { (Regional } \\
\text { ) Police }\end{array}$ & $\begin{array}{l}17- \\
\text { Dec- } \\
16\end{array}$ & SCJ & Unclear & N/A & $\begin{array}{l}2016 \\
\text { ONSC } \\
7986, \\
{[2016]} \\
\text { OJ No } \\
6752\end{array}$ & $\begin{array}{l}\text { Granted } \\
\text { After } \\
\text { Notice }\end{array}$ & N/A & Unclear & $\begin{array}{l}23 \text { Days: } \\
\text { Nov 24, } \\
2016 \text { to } \\
\text { Dec } 17 \text {, } \\
2016\end{array}$ & $\begin{array}{l}\text { Beaudoi } \\
\mathrm{n}\end{array}$ & Unclear & Yes \\
\hline 133 & $\begin{array}{l}R v \\
\text { Samuels }\end{array}$ & $\begin{array}{l}04- \\
\text { Jan-17 }\end{array}$ & $\mathrm{SCJ}$ & $\begin{array}{l}\text { Respond } \\
\text { ing Party }\end{array}$ & $\begin{array}{l}2016 \\
\text { ONSC } \\
7748, \\
\end{array}$ & $\begin{array}{l}2017 \\
\text { ONSC } \\
67, \\
\end{array}$ & $\begin{array}{l}\text { Granted } \\
\text { After } \\
\text { Notice } \\
\end{array}$ & N/A & Unclear & $\begin{array}{l}25 \text { Days: } \\
\text { Dec } 9 \text {, } \\
2016 \text { to }\end{array}$ & Myers & $\begin{array}{l}\text { Attempt to } \\
\text { stay criminal } \\
\text { case through }\end{array}$ & Yes \\
\hline
\end{tabular}




\begin{tabular}{|c|c|c|c|c|c|c|c|c|c|c|c|c|c|}
\hline & & & & & $\begin{array}{l}{[2016] \text { OJ }} \\
\text { No } 6396\end{array}$ & $\begin{array}{l}{[2017]} \\
\text { OJ No } 20\end{array}$ & & & & $\begin{array}{l}\text { Jan 4, } \\
2017\end{array}$ & & $\begin{array}{l}\text { civil } \\
\text { proceedings }\end{array}$ & \\
\hline 134 & $\begin{array}{l}\text { Noddle v } \\
\text { Canada } \\
\text { (Attorney } \\
\text { General) }\end{array}$ & $\begin{array}{l}10- \\
\text { Jan-17 }\end{array}$ & SCJ & $\begin{array}{l}\text { Respond } \\
\text { ing Party }\end{array}$ & $\begin{array}{l}2017 \\
\text { ONSC } \\
215, \\
{[2017] \text { OJ }} \\
\text { No } 154\end{array}$ & N/A & $\begin{array}{l}\text { Notice } \\
\text { Ordered; } \\
\text { Unclear } \\
\text { Result }\end{array}$ & N/A & Unclear & N/A & $\begin{array}{l}\text { Beaudoi } \\
\mathrm{n}\end{array}$ & $\begin{array}{l}\text { Attempt to } \\
\text { re-litigate }\end{array}$ & $\begin{array}{l}\text { Uncl } \\
\text { ear }\end{array}$ \\
\hline 135 & $\begin{array}{l}\text { Mpamugo } \\
\text { v Canada } \\
\text { (Revenue } \\
\text { Agency) }\end{array}$ & $\begin{array}{l}17- \\
\text { Jan-17 }\end{array}$ & SCJ & $\begin{array}{l}\text { Respond } \\
\text { ing Party }\end{array}$ & $\begin{array}{l}2016 \\
\text { ONSC } \\
7569, \\
{[2017] 1} \\
\text { CTC 186 }\end{array}$ & $\begin{array}{l}2017 \\
\text { ONSC } \\
406, \\
{[2017]} \\
\text { OJ No } \\
200\end{array}$ & $\begin{array}{l}\text { Dismisse } \\
\text { d After } \\
\text { Notice }\end{array}$ & N/A & Unclear & $\begin{array}{l}43 \text { Days: } \\
\text { Dec 5, } \\
2016 \text { to } \\
\text { Jan } 17 \text {, } \\
2017\end{array}$ & Myers & $\begin{array}{l}\text { Attempt to } \\
\text { re-litigate } \\
\text { (submissions } \\
\text { suggest } \\
\text { potential } \\
\text { change of } \\
\text { circumstance } \\
\text { s) }\end{array}$ & Yes \\
\hline 136 & $\begin{array}{l}\text { Van } \\
\text { Sluytman } \\
v \\
\text { Departme } \\
\text { nt of } \\
\text { Justice } \\
\text { (Canada) }\end{array}$ & $\begin{array}{l}23- \\
\text { Jan-17 }\end{array}$ & SCJ & $\begin{array}{l}\text { Respond } \\
\text { ing Party }\end{array}$ & $\begin{array}{l}\text { N/A (Jan } \\
5,2017 \\
\text { per appeal } \\
\text { decision) }\end{array}$ & $\begin{array}{l}2017 \\
\text { ONSC } \\
481, \\
2017 \\
\text { Carswell } \\
\text { Ont } 9603\end{array}$ & $\begin{array}{l}\text { Granted } \\
\text { After } \\
\text { Notice }\end{array}$ & $\begin{array}{l}\text { Affirme } \\
\text { d: } 2018 \\
\text { ONCA } \\
32,2018 \\
\text { Carswell } \\
\text { Ont } 301\end{array}$ & Unclear & $\begin{array}{l}\text { 18 Days: } \\
\text { Jan 5, } \\
2017 \text { to } \\
\text { Jan 23, } \\
2017 \text { (to } \\
\text { Jan 16, } \\
2018 \text { ) }\end{array}$ & Wood & $\begin{array}{l}\text { Statute- } \\
\text { barred, many } \\
\text { actions }\end{array}$ & Yes \\
\hline 137 & $\begin{array}{l}\text { Van } \\
\text { Sluytman } \\
\text { v Orillia } \\
\text { Soldiers' } \\
\text { Memorial } \\
\text { Hospital }\end{array}$ & $\begin{array}{l}27- \\
\text { Jan-17 }\end{array}$ & SCJ & Judge & N/A & $\begin{array}{l}2017 \\
\text { ONSC } \\
692, \\
{[2017]} \\
\text { OJ No } \\
445\end{array}$ & $\begin{array}{l}\text { Granted } \\
\text { After } \\
\text { Notice }\end{array}$ & $\begin{array}{l}\text { Affirme } \\
\text { d: } 2018 \\
\text { ONCA } \\
32,2018 \\
\text { Carswell } \\
\text { Ont 301, } \\
2017 \\
\text { ONSC } \\
1359, \\
\text { [2017] } \\
\text { OJ No } \\
969 \text { (Div } \\
\text { Ct) }\end{array}$ & Unclear & $\begin{array}{l}\text { 24 Days: } \\
\text { Jan } 3 \text {, } \\
2017 \text { to } \\
\text { Jan } 27, \\
2017 \text { to } \\
\text { Jan } 16, \\
2018\end{array}$ & DiLuca & $\begin{array}{l}\text { Statute- } \\
\text { barred, many } \\
\text { actions }\end{array}$ & Yes \\
\hline 138 & $\begin{array}{l}222028 \\
\text { Ontario } \\
\text { Inc v } \\
\text { Adams }\end{array}$ & $\begin{array}{l}27- \\
\text { Jan-17 }\end{array}$ & SCJ & $\begin{array}{l}\text { Respond } \\
\text { ing Party }\end{array}$ & $\begin{array}{l}2017 \\
\text { ONSC } \\
690, \\
{[2017] \text { OJ }} \\
\text { No } 565\end{array}$ & N/A & $\begin{array}{l}\text { Notice } \\
\text { Not } \\
\text { Ordered }\end{array}$ & N/A & Unclear & N/A & $\begin{array}{l}\text { Matheso } \\
\mathrm{n}\end{array}$ & $\begin{array}{l}\text { Badly drafted } \\
\text { claim } \\
\text { alleging } \\
\text { misappropriat } \\
\text { ion of funds }\end{array}$ & $\begin{array}{l}\text { Non- } \\
\text { Law } \\
\text { yer } \\
\text { Purp } \\
\text { orts } \\
\text { to } \\
\text { Act }\end{array}$ \\
\hline 139 & $\begin{array}{l}\text { Bresnark } \\
\text { v Canada }\end{array}$ & $\begin{array}{l}31- \\
\text { Jan-17 }\end{array}$ & SCJ & $\begin{array}{l}\text { Respond } \\
\text { ing Party }\end{array}$ & $\begin{array}{l}2017 \\
\text { ONSC } \\
767, \\
{[2017] \text { OJ }} \\
\text { No } 960\end{array}$ & N/A & $\begin{array}{l}\text { Notice } \\
\text { Ordered; } \\
\text { Unclear } \\
\text { Result }\end{array}$ & N/A & Unclear & N/A & $\begin{array}{l}\text { Chiappe } \\
\text { tta }\end{array}$ & Unclear & $\begin{array}{l}\text { Uncl } \\
\text { ear }\end{array}$ \\
\hline 140 & $\begin{array}{l}\text { Caliciuri } \\
v \\
\text { Matthias }\end{array}$ & $\begin{array}{l}07- \\
\text { Feb- } \\
17\end{array}$ & SCJ & $\begin{array}{l}\text { Respond } \\
\text { ing Party }\end{array}$ & N/A & $\begin{array}{l}2017 \\
\text { ONSC } \\
748, \\
{[2017]} \\
\text { OJ No } \\
547\end{array}$ & $\begin{array}{l}\text { Dismisse } \\
\mathrm{d} \text { in } \\
\text { Context } \\
\text { of Other } \\
\text { Motion }\end{array}$ & N/A & Unclear & $\begin{array}{l}\text { 137 Days } \\
\text { (formal } \\
\text { motion } \\
\text { in } \\
\text { conjuncti } \\
\text { on with } \\
\text { Rule 21): } \\
\text { Sept 23, } \\
2016 \text { to }\end{array}$ & $\begin{array}{l}\text { MacLeo } \\
\text { d }\end{array}$ & $\begin{array}{l}\text { Alleged } \\
\text { attempt to re- } \\
\text { litigate }\end{array}$ & No \\
\hline
\end{tabular}




\begin{tabular}{|c|c|c|c|c|c|c|c|c|c|c|c|c|c|}
\hline & & & & & & & & & & $\begin{array}{l}\text { Feb 7, } \\
2017\end{array}$ & & & \\
\hline 141 & $\begin{array}{l}\text { Lin } v \\
\text { Ontario } \\
\text { (Ombuds } \\
\text { man) }\end{array}$ & $\begin{array}{l}10- \\
\text { Feb- } \\
17\end{array}$ & SCJ & Unclear & N/A & $\begin{array}{l}2017 \\
\text { ONSC } \\
966, \\
{[2017]} \\
\text { OJ No } \\
699\end{array}$ & $\begin{array}{l}\text { Granted } \\
\text { After } \\
\text { Notice }\end{array}$ & N/A & Unclear & $\begin{array}{l}79 \text { Days: } \\
\text { Nov 23, } \\
2016 \text { to } \\
\text { Feb } 10, \\
2017\end{array}$ & $\begin{array}{l}\text { Chiappe } \\
\text { tta }\end{array}$ & Many actions & Yes \\
\hline 142 & $\begin{array}{l}\text { Milne v } \\
\text { Livingsto } \\
n\end{array}$ & $\begin{array}{l}27- \\
\text { Feb- } \\
17\end{array}$ & SCJ & $\begin{array}{l}\text { Respond } \\
\text { ing Party }\end{array}$ & $\begin{array}{l}2017 \\
\text { ONSC } \\
1367, \\
{[2017] \text { OJ }} \\
\text { No } 1031\end{array}$ & N/A & $\begin{array}{l}\text { Notice } \\
\text { Ordered; } \\
\text { Unclear } \\
\text { Result }\end{array}$ & N/A & Unclear & N/A & $\begin{array}{l}\text { Chiappe } \\
\text { tta }\end{array}$ & "On its face" & $\begin{array}{l}\text { Uncl } \\
\text { ear }\end{array}$ \\
\hline 143 & $\begin{array}{l}\text { Ellis } v \\
\text { Wernick }\end{array}$ & $\begin{array}{l}03- \\
\text { Mar- } \\
17\end{array}$ & SCJ & $\begin{array}{l}\text { Respond } \\
\text { ing Party }\end{array}$ & N/A & $\begin{array}{l}2017 \\
\text { ONSC } \\
1461, \\
{[2017]} \\
\text { OJ No } \\
1070\end{array}$ & $\begin{array}{l}\text { Granted } \\
\text { After } \\
\text { Notice }\end{array}$ & N/A & Unclear & N/A & $\begin{array}{l}\text { Marrocc } \\
\mathrm{o}\end{array}$ & $\begin{array}{l}\text { Attempt to } \\
\text { challenge } \\
\text { Royal } \\
\text { Proclamation } \\
\text { of } 1763\end{array}$ & Yes \\
\hline 144 & $\begin{array}{l}\text { Strang } v \\
\text { Toronto } \\
\text { (City) }\end{array}$ & $\begin{array}{l}10- \\
\text { Mar- } \\
17\end{array}$ & SCJ & Judge & $\begin{array}{l}2017 \\
\text { ONSC } \\
997, \\
{[2017] \text { OJ }} \\
\text { No } 680\end{array}$ & $\begin{array}{l}2017 \\
\text { ONSC } \\
1622, \\
{[2017]} \\
\text { OJ No } \\
1295\end{array}$ & $\begin{array}{l}\text { Granted } \\
\text { After } \\
\text { Notice }\end{array}$ & N/A & Unclear & $\begin{array}{l}\text { 29 Days: } \\
\text { Feb 9, } \\
2017 \text { to } \\
\text { March } \\
10,2017\end{array}$ & Myers & $\begin{array}{l}\text { Hallmarks of } \\
\text { vexatiousness }\end{array}$ & Yes \\
\hline 145 & $\begin{array}{l}\text { Strang } v \\
\text { Paragon } \\
\text { Security }\end{array}$ & $\begin{array}{l}10- \\
\text { Mar- } \\
17\end{array}$ & SCJ & Judge & $\begin{array}{l}2017 \\
\text { ONSC } \\
996, \\
{[2017] \text { OJ }} \\
\text { No } 684\end{array}$ & $\begin{array}{l}2017 \\
\text { ONSC } \\
1623, \\
{[2017]} \\
\text { OJ No } \\
1299\end{array}$ & $\begin{array}{l}\text { Granted } \\
\text { After } \\
\text { Notice }\end{array}$ & N/A & Unclear & $\begin{array}{l}\text { 29 Days: } \\
\text { Feb 9, } \\
2017 \text { to } \\
\text { March } \\
10,2017\end{array}$ & Myers & $\begin{array}{l}\text { Hallmarks of } \\
\text { vexatiousness }\end{array}$ & Yes \\
\hline 146 & $\begin{array}{l}\text { Strang } v \\
\text { Ontario } \\
\text { Public } \\
\text { Service } \\
\text { Employee } \\
\text { s Union }\end{array}$ & $\begin{array}{l}10- \\
\text { Mar- } \\
17\end{array}$ & SCJ & Judge & $\begin{array}{l}2017 \\
\text { ONSC } \\
995, \\
{[2017] \text { OJ }} \\
\text { No } 683\end{array}$ & $\begin{array}{l}2017 \\
\text { ONSC } \\
1625, \\
{[2017]} \\
\text { OJ No } \\
1298\end{array}$ & $\begin{array}{l}\text { Granted } \\
\text { After } \\
\text { Notice }\end{array}$ & N/A & Unclear & $\begin{array}{l}\text { 29 Days: } \\
\text { Feb 9, } \\
2017 \text { to } \\
\text { March } \\
10,2017\end{array}$ & Myers & $\begin{array}{l}\text { Hallmarks of } \\
\text { vexatiousness }\end{array}$ & Yes \\
\hline 147 & $\begin{array}{l}\text { Strang } v \\
\text { Ontario }\end{array}$ & $\begin{array}{l}10- \\
\text { Mar- } \\
17\end{array}$ & SCJ & Judge & $\begin{array}{l}2017 \\
\text { ONSC } \\
994, \\
{[2017] \text { OJ }} \\
\text { No } 682\end{array}$ & $\begin{array}{l}2017 \\
\text { ONSC } \\
1625, \\
{[2017]} \\
\text { OJ No } \\
1297\end{array}$ & $\begin{array}{l}\text { Granted } \\
\text { After } \\
\text { Notice }\end{array}$ & N/A & Unclear & $\begin{array}{l}\text { 29 Days: } \\
\text { Feb 9, } \\
2017 \text { to } \\
\text { March } \\
10,2017\end{array}$ & Myers & $\begin{array}{l}\text { Hallmarks of } \\
\text { vexatiousness }\end{array}$ & Yes \\
\hline 148 & $\begin{array}{l}\text { Strang } v \\
\text { Ontario } \\
\text { (Treasury } \\
\text { Board) }\end{array}$ & $\begin{array}{l}13- \\
\text { Mar- } \\
17\end{array}$ & SCJ & Judge & $\begin{array}{l}2017 \\
\text { ONSC } \\
993, \\
{[2017] \text { OJ }} \\
\text { No } 681\end{array}$ & $\begin{array}{l}2017 \\
\text { ONSC } \\
1638, \\
{[2017]} \\
\text { OJ No } \\
1296\end{array}$ & $\begin{array}{l}\text { Granted } \\
\text { After } \\
\text { Notice }\end{array}$ & N/A & Unclear & $\begin{array}{l}\text { 32 Days: } \\
\text { Feb 9, } \\
2017 \text { to } \\
\text { March } \\
13,2017\end{array}$ & Myers & $\begin{array}{l}\text { Hallmarks of } \\
\text { vexatiousness }\end{array}$ & Yes \\
\hline 149 & $\begin{array}{l}\text { Zhang } v \\
\text { Zang }\end{array}$ & $\begin{array}{l}17- \\
\text { Mar- } \\
17\end{array}$ & SCJ & $\begin{array}{l}\text { Respond } \\
\text { ing Party }\end{array}$ & $\begin{array}{l}2017 \\
\text { ONSC } \\
1183, \\
{[2017] \text { OJ }} \\
\text { No } 950 \\
\end{array}$ & $\begin{array}{l}2017 \\
\text { ONSC } \\
1772, \\
{[2017]}\end{array}$ & $\begin{array}{l}\text { Granted } \\
\text { After } \\
\text { Notice }\end{array}$ & N/A & Unclear & $\begin{array}{l}23 \text { Days: } \\
\text { Feb 22, } \\
2017 \text { to } \\
\text { March } \\
17,2017\end{array}$ & $\begin{array}{l}\text { Beaudoi } \\
\mathrm{n}\end{array}$ & $\begin{array}{l}\text { Attempt to } \\
\text { re-litigate } \\
\text { allegations of } \\
\text { spying }\end{array}$ & Yes \\
\hline
\end{tabular}




\begin{tabular}{|c|c|c|c|c|c|c|c|c|c|c|c|c|c|}
\hline & & & & & & $\begin{array}{l}\text { OJ No } \\
1858\end{array}$ & & & & & & & \\
\hline 150 & $\begin{array}{l}\text { DeMasi v } \\
\text { Toronto } \\
\text { (City) }\end{array}$ & $\begin{array}{l}24- \\
\text { Mar- } \\
17\end{array}$ & SCJ & Unclear & N/A & $\begin{array}{l}2017 \\
\text { ONSC } \\
1916, \\
{[2017]} \\
\text { OJ No } \\
1541\end{array}$ & $\begin{array}{l}\text { Granted } \\
\text { After } \\
\text { Notice }\end{array}$ & N/A & None & $\begin{array}{l}162 \\
\text { Days: } \\
\text { Oct 13, } \\
2016 \text { to } \\
\text { March } \\
24,2017\end{array}$ & Dunphy & $\begin{array}{l}\text { Incomprehen } \\
\text { sible }\end{array}$ & Yes \\
\hline 151 & $\begin{array}{l}\text { Fex } v \\
\text { McCarthy } \\
\text { Tetrault } \\
\text { LLP }\end{array}$ & $\begin{array}{l}27- \\
\text { Mar- } \\
17\end{array}$ & SCJ & $\begin{array}{l}\text { Respond } \\
\text { ing Party }\end{array}$ & $\begin{array}{l}2017 \\
\text { ONSC } \\
1280, \\
{[2017] \text { OJ }} \\
\text { No } 905\end{array}$ & $\begin{array}{l}2017 \\
\text { ONSC } \\
1907, \\
{[2017]} \\
\text { OJ No } \\
1548\end{array}$ & $\begin{array}{l}\text { Granted } \\
\text { After } \\
\text { Notice }\end{array}$ & N/A & Unclear & $\begin{array}{l}\text { 31 Days: } \\
\text { Feb 24, } \\
2017 \text { to } \\
\text { March } \\
27,2017\end{array}$ & Sweeny & $\begin{array}{l}\text { Attempt to } \\
\text { re-litigate }\end{array}$ & Yes \\
\hline 152 & $\begin{array}{l}\text { Dias } v \\
\text { Ontario } \\
\text { (Workpla } \\
\text { ce Safety } \\
\& \\
\text { Insurance } \\
\text { Appeal } \\
\text { Tribunal) }\end{array}$ & $\begin{array}{l}27- \\
\text { Mar- } \\
17\end{array}$ & SCJ & $\begin{array}{l}\text { Respond } \\
\text { ing Party }\end{array}$ & $\begin{array}{l}2017 \\
\text { ONSC } \\
1277, \\
{[2017] \text { OJ }} \\
\text { No } 902\end{array}$ & $\begin{array}{l}2017 \\
\text { ONSC } \\
1888, \\
{[2017]} \\
\text { OJ No } \\
1542\end{array}$ & $\begin{array}{l}\text { Granted } \\
\text { After } \\
\text { Notice }\end{array}$ & N/A & Unclear & $\begin{array}{l}\text { 31 Days: } \\
\text { Feb 24, } \\
2017 \text { to } \\
\text { March } \\
27,2017\end{array}$ & Sweeny & $\begin{array}{l}\text { Attempt to } \\
\text { re-litigate }\end{array}$ & Yes \\
\hline 153 & $\begin{array}{l}\text { Van } \\
\text { Sluytman } \\
v \\
\text { Brewster }\end{array}$ & $\begin{array}{l}28- \\
\text { Mar- } \\
17\end{array}$ & SCJ & $\begin{array}{l}\text { Respond } \\
\text { ing Party }\end{array}$ & N/A & $\begin{array}{l}2017 \\
\text { ONSC } \\
1957, \\
{[2017]} \\
\text { OJ No } \\
2287\end{array}$ & $\begin{array}{l}\text { Granted } \\
\text { After } \\
\text { Notice }\end{array}$ & $\begin{array}{l}\text { Affirme } \\
\text { d: } 2018 \\
\text { ONCA } \\
32,2018 \\
\text { Carswell } \\
\text { Ont 301 }\end{array}$ & Unclear & $\begin{array}{l}\text { 61 Days: } \\
\text { Jan 26, } \\
2017 \text { to } \\
\text { March } \\
28,2017\end{array}$ & DiLuca & $\begin{array}{l}\text { Obviously } \\
\text { statute-barred }\end{array}$ & Yes \\
\hline 154 & $\begin{array}{l}\text { White v } \\
\text { Graham }\end{array}$ & $\begin{array}{l}10- \\
\text { Apr- } \\
17\end{array}$ & SCJ & $\begin{array}{l}\text { Respond } \\
\text { ing Party }\end{array}$ & $\begin{array}{l}2017 \\
\text { ONSC } \\
1268, \\
{[2017] \text { OJ }} \\
\text { No } 948\end{array}$ & $\begin{array}{l}2017 \\
\text { ONSC } \\
2236, \\
{[2017]} \\
\text { OJ No } \\
1856\end{array}$ & $\begin{array}{l}\text { Granted } \\
\text { After } \\
\text { Notice }\end{array}$ & N/A & Unclear & $\begin{array}{l}\text { 47 Days: } \\
\text { Feb 22, } \\
2017 \text { to } \\
\text { April } 10, \\
2017\end{array}$ & $\begin{array}{l}\text { Beaudoi } \\
\mathrm{n}\end{array}$ & $\begin{array}{l}\text { Outrageous, } \\
\text { delusional } \\
\text { claims }\end{array}$ & Yes \\
\hline 155 & $\begin{array}{l}\text { Reyes } v \\
K L\end{array}$ & $\begin{array}{l}12- \\
\text { Apr- } \\
17\end{array}$ & SCJ & $\begin{array}{l}\text { Respond } \\
\text { ing Party }\end{array}$ & $\begin{array}{l}2017 \\
\text { ONSC } \\
308, \\
{[2017] \text { OJ }} \\
\text { No } 192\end{array}$ & $\begin{array}{l}2017 \\
\text { ONSC } \\
2304, \\
{[2017]} \\
\text { OJ No } \\
2195\end{array}$ & $\begin{array}{l}\text { Granted } \\
\text { After } \\
\text { Notice }\end{array}$ & N/A & Unclear & $\begin{array}{l}\text { 90 Days: } \\
\text { Jan } 12 \text {, } \\
2017 \text { to } \\
\text { April 12, } \\
2017\end{array}$ & Faieta & $\begin{array}{l}\text { Scandalous } \\
\text { and/or } \\
\text { statute-barred } \\
\text { employment } \\
\text { allegations }\end{array}$ & Yes \\
\hline 156 & $\begin{array}{l}\text { Ramsarra } \\
n v \text { Assaly } \\
\text { Asset } \\
\text { Managem } \\
\text { ent Corp }\end{array}$ & $\begin{array}{l}\text { 19- } \\
\text { Apr- } \\
17\end{array}$ & SCJ & $\begin{array}{l}\text { Respond } \\
\text { ing Party }\end{array}$ & $\begin{array}{l}2017 \\
\text { ONSC } \\
2394, \\
{[2017] \text { OJ }} \\
\text { No } 1937\end{array}$ & N/A & $\begin{array}{l}\text { Notice } \\
\text { Not } \\
\text { Ordered }\end{array}$ & N/A & Unclear & N/A & $\begin{array}{l}\text { Beaudoi } \\
\mathrm{n}\end{array}$ & $\begin{array}{l}\text { Trying to } \\
\text { explain why } \\
\text { abusive } \\
\text { through } \\
\text { argument }\end{array}$ & No \\
\hline 157 & $\begin{array}{l}\text { Carby- } \\
\text { Samuels v } \\
\text { Carby- } \\
\text { Samuels }\end{array}$ & $\begin{array}{l}12- \\
\text { May- } \\
17\end{array}$ & SCJ & $\begin{array}{l}\text { Respond } \\
\text { ing Party }\end{array}$ & $\begin{array}{l}2017 \\
\text { ONSC } \\
2911, \\
\text { [2017] OJ } \\
\text { No 2406 }\end{array}$ & N/A & $\begin{array}{l}\text { Notice } \\
\text { Not } \\
\text { Ordered }\end{array}$ & N/A & Unclear & N/A & $\begin{array}{l}\text { Beaudoi } \\
\mathrm{n}\end{array}$ & $\begin{array}{l}\text { "Clearly } \\
\text { inappropriate } \\
\text { " attempt to } \\
\text { short circuit } \\
\text { Defendant's } \\
\text { summary } \\
\text { judgment } \\
\text { motion after } \\
\text { failure to file }\end{array}$ & $\begin{array}{l}\text { Uncl } \\
\text { ear }\end{array}$ \\
\hline
\end{tabular}




\begin{tabular}{|c|c|c|c|c|c|c|c|c|c|c|c|c|c|}
\hline & & & & & & & & & & & & $\begin{array}{l}\text { notice of } \\
\text { motion }\end{array}$ & \\
\hline 158 & $\begin{array}{l}\text { Foster v } \\
\text { Children' } \\
\text { s Aid } \\
\text { Society }\end{array}$ & $\begin{array}{l}15- \\
\text { May- } \\
17\end{array}$ & SCJ & $\begin{array}{l}\text { Respond } \\
\text { ing Party }\end{array}$ & $\begin{array}{l}2017 \\
\text { ONSC } \\
2086, \\
{[2017] \text { OJ }} \\
\text { No } 2692\end{array}$ & $\begin{array}{l}2017 \\
\text { ONSC } \\
2990, \\
{[2017]} \\
\text { OJ No } \\
2693\end{array}$ & $\begin{array}{l}\text { Granted } \\
\text { After } \\
\text { Notice }\end{array}$ & $\mathrm{N} / \mathrm{A}$ & Unclear & $\begin{array}{l}\text { 42 Days: } \\
\text { April 3, } \\
2017 \text { to } \\
\text { May 15, } \\
2017\end{array}$ & $\begin{array}{l}\text { Beaudoi } \\
\mathrm{n}\end{array}$ & $\begin{array}{l}\text { No material } \\
\text { facts pleaded } \\
\text { - simply } \\
\text { demanded } \\
\text { money }\end{array}$ & Yes \\
\hline 159 & $\begin{array}{l}\text { Korolew } \\
v \\
\text { Canadian } \\
\text { Union of } \\
\text { Public } \\
\text { Employee } \\
s\end{array}$ & $\begin{array}{l}05- \\
\text { Jun-17 }\end{array}$ & $\mathrm{SCJ}$ & $\begin{array}{l}\text { Respond } \\
\text { ing Party }\end{array}$ & $\begin{array}{l}2017 \\
\text { ONSC } \\
2984, \\
{[2017] \text { OJ }} \\
\text { No 2696 }\end{array}$ & $\begin{array}{l}2017 \\
\text { ONSC } \\
3474, \\
{[2017]} \\
\text { OJ No } \\
2949\end{array}$ & $\begin{array}{l}\text { Granted } \\
\text { After } \\
\text { Notice }\end{array}$ & $\mathrm{N} / \mathrm{A}$ & None & $\begin{array}{l}21 \text { Days: } \\
\text { May 15, } \\
2017 \text { to } \\
\text { June 5, } \\
2017\end{array}$ & $\begin{array}{l}\text { Beaudoi } \\
\mathrm{n}\end{array}$ & $\begin{array}{l}\text { Statement of } \\
\text { Claim } \\
\text { containing } \\
\text { one word: } \\
\text { Dafamation } \\
\text { (sic) }\end{array}$ & Yes \\
\hline 160 & $\begin{array}{l}\text { Gebremar } \\
\text { iam v } \\
\text { Jenkins }\end{array}$ & $\begin{array}{l}21- \\
\text { Jun-17 }\end{array}$ & $\mathrm{SCJ}$ & Unclear & N/A & $\begin{array}{l}2017 \\
\text { ONSC } \\
3845 \\
{[2017]} \\
\text { OJ No } \\
3197\end{array}$ & $\begin{array}{l}\text { Granted } \\
\text { After } \\
\text { Notice }\end{array}$ & $\mathrm{N} / \mathrm{A}$ & Unclear & $\begin{array}{l}55 \text { Days: } \\
\text { April 27, } \\
2017 \text { to } \\
\text { June } 21, \\
2017\end{array}$ & Glustein & $\begin{array}{l}\text { Attempt to } \\
\text { re-litigate, } \\
\text { unknown } \\
\text { claim }\end{array}$ & Yes \\
\hline 161 & $\begin{array}{l}\text { Kashani v } \\
\text { Algonqui } \\
\text { n College }\end{array}$ & $\begin{array}{l}28- \\
\text { Jun-17 }\end{array}$ & SCJ & $\begin{array}{l}\text { Respond } \\
\text { ing Party }\end{array}$ & $\begin{array}{l}2017 \\
\text { ONSC } \\
3971, \\
{[2017] \text { OJ }} \\
\text { No } 3513\end{array}$ & N/A & $\begin{array}{l}\text { Notice } \\
\text { Ordered; } \\
\text { Unclear } \\
\text { Result }\end{array}$ & N/A & Unclear & N/A & $\begin{array}{l}\text { Beaudoi } \\
\mathrm{n}\end{array}$ & $\begin{array}{l}\text { Manifestly } \\
\text { frivolous } \\
\text { and/or in the } \\
\text { wrong Court }\end{array}$ & Yes \\
\hline 162 & $\begin{array}{l}\text { Khan v } \\
\text { Krylov \& } \\
\text { Company } \\
\text { LLP }\end{array}$ & $\mathrm{N} / \mathrm{A}$ & SCJ & Unclear & N/A & $\mathrm{N} / \mathrm{A}$ & $\begin{array}{l}\text { Dismisse } \\
\text { d After } \\
\text { Appeal }\end{array}$ & $\begin{array}{l}\text { Reverse } \\
\text { d: } 2017 \\
\text { ONCA } \\
625, \\
2017 \\
\text { Carswell } \\
\text { Ont } \\
16235\end{array}$ & $\begin{array}{l}\$ 3,000 \\
\text { at CA; } \\
\$ 2,000 \\
\text { at SCJ }\end{array}$ & $\mathrm{N} / \mathrm{A}$ & Daley & $\begin{array}{l}\text { Not "clearest } \\
\text { of cases" }\end{array}$ & Yes \\
\hline 163 & $\begin{array}{l}\text { R.v } \\
\text { Jayaraj }\end{array}$ & $\begin{array}{l}03- \\
\text { Nov- } \\
14\end{array}$ & $\begin{array}{l}\text { Div } \\
\mathrm{Ct}\end{array}$ & Judge & N/A & $\begin{array}{l}2014 \\
\text { ONSC } \\
6367,69 \\
\text { CPC } \\
\text { (7th) } 287\end{array}$ & $\begin{array}{l}\text { Granted } \\
\text { After } \\
\text { Notice }\end{array}$ & $\mathrm{N} / \mathrm{A}$ & None & $\begin{array}{l}\text { 14 Days: } \\
\text { Oct 20, } \\
2014 \text { to } \\
\text { Nov } 3 \text {, } \\
2014\end{array}$ & $\begin{array}{l}\text { Nordhei } \\
\text { mer }\end{array}$ & $\begin{array}{l}\text { Seeking to } \\
\text { quash } \\
\text { appointments } \\
\text { of judges }\end{array}$ & $\begin{array}{l}\text { Uncl } \\
\text { ear }\end{array}$ \\
\hline 164 & $\begin{array}{l}\text { Beard } \\
\text { Winter } \\
\text { LLP v } \\
\text { Shekhdar }\end{array}$ & $\begin{array}{l}15- \\
\text { Mar- } \\
16\end{array}$ & $\begin{array}{l}\text { Div } \\
\mathrm{Ct}\end{array}$ & Unclear & N/A & $\begin{array}{l}2016 \\
\text { ONSC } \\
1852 \\
{[2016]} \\
\text { OJ No } \\
1350\end{array}$ & $\begin{array}{l}\text { Granted } \\
\text { After } \\
\text { Notice }\end{array}$ & $\mathrm{N} / \mathrm{A}$ & None & $\begin{array}{l}\text { 1 Day: } \\
\text { Judge } \\
\text { Asked } \\
\text { Day } \\
\text { Before }\end{array}$ & $\begin{array}{l}\text { Marrocc } \\
\text { o }\end{array}$ & $\begin{array}{l}\text { Jurisdictional } \\
\text { submissions } \\
\text { sought on } \\
\text { own } \\
\text { submission }\end{array}$ & Yes \\
\hline 165 & $\begin{array}{l}\text { Lin } v \\
\text { Zhang }\end{array}$ & $\begin{array}{l}18- \\
\text { Apr- } \\
16\end{array}$ & $\begin{array}{l}\text { Div } \\
\mathrm{Ct}\end{array}$ & Unclear & N/A & $\begin{array}{l}2016 \\
\text { ONSC } \\
2485 \\
{[2016]} \\
\text { OJ No } \\
1988\end{array}$ & $\begin{array}{l}\text { Granted } \\
\text { After } \\
\text { Notice }\end{array}$ & $\mathrm{N} / \mathrm{A}$ & None & $\begin{array}{l}\text { 27 Days: } \\
\text { March } \\
22,2016 \\
\text { to April } \\
18,2016\end{array}$ & Sachs & $\begin{array}{l}\text { Seeking } \\
\text { damages in } \\
\text { Divisional } \\
\text { Court based } \\
\text { on Landlord- } \\
\text { Tenant } \\
\text { proceeding }\end{array}$ & Yes \\
\hline 166 & $\begin{array}{l}\text { Lin } v \\
\text { Springbo } \\
\text { ard }\end{array}$ & $\begin{array}{l}22- \\
\text { Jul-16 }\end{array}$ & $\begin{array}{l}\text { Div } \\
\mathrm{Ct}\end{array}$ & Unclear & N/A & $\begin{array}{l}2016 \\
\text { ONSC } \\
4705\end{array}$ & $\begin{array}{l}\text { Granted } \\
\text { After } \\
\text { Notice }\end{array}$ & $\begin{array}{l}\text { Affirme } \\
\text { d: } 2016 \\
\text { ONCA }\end{array}$ & Unclear & $\begin{array}{l}\text { 42 Days: } \\
\text { June } 10 \text {, } \\
2016 \text { to }\end{array}$ & Sachs & $\begin{array}{l}\text { Seeks relief } \\
\text { that cannot be } \\
\text { granted in }\end{array}$ & Yes \\
\hline
\end{tabular}




\begin{tabular}{|c|c|c|c|c|c|c|c|c|c|c|c|c|c|}
\hline & & & & & & $\begin{array}{l}{[2016]} \\
\text { OJ No } \\
3917\end{array}$ & & $\begin{array}{l}787, \\
{[2016]} \\
\text { OJ No } \\
6072, \\
\text { Leave to } \\
\text { appeal } \\
\text { refused: } \\
\text { [2016] } \\
\text { SCCA } \\
\text { No 562 }\end{array}$ & & $\begin{array}{l}\text { July } 22 \text {, } \\
2016 \text { to } \\
\text { Oct } 26, \\
2016 \text { to } \\
\text { Feb 23, } \\
2017\end{array}$ & & $\begin{array}{l}\text { judicial } \\
\text { review }\end{array}$ & \\
\hline 167 & $\begin{array}{l}\text { Cerqueira } \\
\text { Estate v } \\
\text { Ontario }\end{array}$ & $\begin{array}{l}18- \\
\text { Aug- } \\
16\end{array}$ & $\begin{array}{l}\text { Div } \\
\mathrm{Ct}\end{array}$ & Unclear & N/A & $\begin{array}{l}2016 \\
\text { ONSC } \\
5112, \\
{[2016]} \\
\text { OJ No } \\
4353\end{array}$ & $\begin{array}{l}\text { Granted } \\
\text { After } \\
\text { Notice }\end{array}$ & N/A & None & $\begin{array}{l}\text { 77 Days: } \\
\text { June 2, } \\
2016 \text { to } \\
\text { Aug 18, } \\
2016\end{array}$ & Sachs & $\begin{array}{l}\text { Attempt to } \\
\text { re-litigate } \\
\text { (dealt with by } \\
\text { SJ in SCJ) }\end{array}$ & Yes \\
\hline 168 & $\begin{array}{l}\text { Gates v } \\
\text { Humane } \\
\text { Society of } \\
\text { Canada } \\
\text { for the } \\
\text { Protectio } \\
n \text { of } \\
\text { Animals } \\
\text { and the } \\
\text { Environm } \\
\text { ent (cob } \\
\text { The } \\
\text { Humane } \\
\text { Society of } \\
\text { Canada) }\end{array}$ & $\begin{array}{l}24- \\
\text { Aug- } \\
16\end{array}$ & $\begin{array}{l}\text { Div } \\
\mathrm{Ct}\end{array}$ & Unclear & N/A & $\begin{array}{l}2016 \\
\text { ONSC } \\
5345, \\
{[2016]} \\
\text { OJ No } \\
4424\end{array}$ & $\begin{array}{l}\text { Granted } \\
\text { After } \\
\text { Notice }\end{array}$ & N/A & $\begin{array}{l}8,000: \\
2016 \\
\text { ONSC } \\
6051, \\
{[2016]} \\
\text { OJ No } \\
4957\end{array}$ & N/A & Horkins & $\begin{array}{l}\text { Dismissal of } \\
\text { appeal of } \\
\text { Small Claims } \\
\text { Court } \\
\text { decision after } \\
\text { many } \\
\text { frivolous } \\
\text { steps }\end{array}$ & Yes \\
\hline 169 & $\begin{array}{l}\text { Adamson } \\
v \\
\text { Iracleous }\end{array}$ & $\begin{array}{l}27- \\
\text { Sep- } \\
16\end{array}$ & $\begin{array}{l}\text { Div } \\
\mathrm{Ct}\end{array}$ & Unclear & $\mathrm{N} / \mathrm{A}$ & $\begin{array}{l}2016 \\
\text { ONSC } \\
6055, \\
{[2016]} \\
\text { OJ No } \\
4943\end{array}$ & $\begin{array}{l}\text { Granted } \\
\text { After } \\
\text { Notice }\end{array}$ & N/A & None & N/A & $\begin{array}{l}\text { Nordhei } \\
\text { mer }\end{array}$ & $\begin{array}{l}\text { Attempt to JR } \\
\text { to "fix to do } \\
\text { what is right" }\end{array}$ & Yes \\
\hline 170 & $\begin{array}{l}\text { El Zayat v } \\
\text { Hausler }\end{array}$ & $\begin{array}{l}28- \\
\text { Sep- } \\
16\end{array}$ & $\begin{array}{l}\text { Div } \\
\mathrm{Ct}\end{array}$ & Unclear & $\mathrm{N} / \mathrm{A}$ & $\begin{array}{l}2016 \\
\text { ONSC } \\
6099, \\
{[2016]} \\
\text { OJ No } \\
4984\end{array}$ & $\begin{array}{l}\text { Granted } \\
\text { After } \\
\text { Notice }\end{array}$ & N/A & None & N/A & $\begin{array}{l}\text { Nordhei } \\
\text { mer }\end{array}$ & $\begin{array}{l}\text { "Motion" } \\
\text { really attempt } \\
\text { to have } \\
\text { second } \\
\text { appeal }\end{array}$ & Yes \\
\hline 171 & $\begin{array}{l}\text { Adamson } \\
v \text { Lo }\end{array}$ & $\begin{array}{l}29- \\
\text { Sep- } \\
16\end{array}$ & $\begin{array}{l}\text { Div } \\
\mathrm{Ct}\end{array}$ & Unclear & N/A & $\begin{array}{l}2016 \\
\text { ONSC } \\
6114, \\
{[2016]} \\
\text { OJ No } \\
5012\end{array}$ & $\begin{array}{l}\text { Granted } \\
\text { After } \\
\text { Notice }\end{array}$ & $\mathrm{N} / \mathrm{A}$ & None & N/A & $\begin{array}{l}\text { Nordhei } \\
\text { mer }\end{array}$ & $\begin{array}{l}\text { Attempt to JR } \\
\text { to "fix to do } \\
\text { what is right" }\end{array}$ & Yes \\
\hline 172 & $\begin{array}{l}\text { Graff v } \\
\text { Capreit } \\
\text { Limited } \\
\text { Partnersh } \\
\text { ip }\end{array}$ & $\begin{array}{l}03- \\
\text { Oct-16 }\end{array}$ & $\begin{array}{l}\text { Div } \\
\mathrm{Ct}\end{array}$ & Unclear & N/A & $\begin{array}{l}2016 \\
\text { ONSC } \\
6173, \\
{[2016]} \\
\text { OJ No } \\
5073\end{array}$ & $\begin{array}{l}\text { Dismisse } \\
\mathrm{d} \text { After } \\
\text { Notice }\end{array}$ & $\mathrm{N} / \mathrm{A}$ & Unclear & N/A & $\begin{array}{l}\text { Nordhei } \\
\text { mer }\end{array}$ & $\begin{array}{l}\text { Landlord } \\
\text { Dispute that } \\
\text { had become } \\
\text { moot }\end{array}$ & Yes \\
\hline
\end{tabular}




\begin{tabular}{|c|c|c|c|c|c|c|c|c|c|c|c|c|c|}
\hline 173 & $\begin{array}{l}\text { Lin v } \\
\text { Toronto } \\
\text { (City) } \\
\text { Police } \\
\text { Services } \\
\text { Board }\end{array}$ & $\begin{array}{l}27- \\
\text { Oct-16 }\end{array}$ & $\begin{array}{l}\text { Div } \\
\mathrm{Ct}\end{array}$ & Unclear & N/A & $\begin{array}{l}2016 \\
\text { ONSC } \\
6736, \\
{[2016]} \\
\text { OJ No } \\
5540\end{array}$ & $\begin{array}{l}\text { Granted } \\
\text { After } \\
\text { Notice }\end{array}$ & N/A & Unclear & $\begin{array}{l}37 \text { Days: } \\
\text { Sept 20, } \\
2016 \text { to } \\
\text { Oct } 27 \text {, } \\
2016\end{array}$ & $\begin{array}{l}\text { Nordhei } \\
\text { mer }\end{array}$ & Unintelligible & Yes \\
\hline 174 & $\begin{array}{l}\text { Stefanizzi } \\
v \text { Ontario } \\
\text { (Landlord } \\
\text { and } \\
\text { Tenant } \\
\text { Board) }\end{array}$ & $\begin{array}{l}09- \\
\text { Nov- } \\
16\end{array}$ & $\begin{array}{l}\text { Div } \\
\mathrm{Ct}\end{array}$ & $\begin{array}{l}\text { Respond } \\
\text { ing Party }\end{array}$ & N/A & $\begin{array}{l}2016 \\
\text { ONSC } \\
6932, \\
{[2016]} \\
\text { OJ No } \\
5779\end{array}$ & $\begin{array}{l}\text { Granted } \\
\text { After } \\
\text { Notice }\end{array}$ & $\mathrm{N} / \mathrm{A}$ & Unclear & N/A & Gauthier & $\begin{array}{l}\text { Div Ct } \\
\text { obviously not } \\
\text { proper forum }\end{array}$ & Yes \\
\hline 175 & $\begin{array}{l}\text { Hemchan } \\
d v \\
\text { Toronto } \\
\text { (City) }\end{array}$ & $\begin{array}{l}16- \\
\text { Nov- } \\
16\end{array}$ & $\begin{array}{l}\text { Div } \\
\mathrm{Ct}\end{array}$ & $\begin{array}{l}\text { Respond } \\
\text { ing Party }\end{array}$ & N/A & 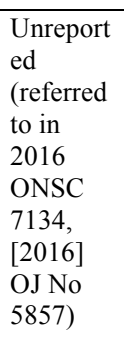 & $\begin{array}{l}\text { Granted } \\
\text { After } \\
\text { Notice }\end{array}$ & $\mathrm{N} / \mathrm{A}$ & None & $\mathrm{N} / \mathrm{A}$ & $\begin{array}{l}\text { Nordhei } \\
\text { mer }\end{array}$ & $\begin{array}{l}\text { No } \\
\text { jurisdiction } \\
\text { for Div Ct }\end{array}$ & Yes \\
\hline 176 & $\begin{array}{l}\text { Coady v } \\
\text { Law } \\
\text { Society of } \\
\text { Upper } \\
\text { Canada }\end{array}$ & $\begin{array}{l}02- \\
\text { Dec- } \\
16\end{array}$ & $\begin{array}{l}\text { Div } \\
\mathrm{Ct}\end{array}$ & Unclear & N/A & $\begin{array}{l}2016 \\
\text { ONSC } \\
7543, \\
{[2016]} \\
\text { OJ No } \\
6194\end{array}$ & $\begin{array}{l}\text { Granted } \\
\text { Without } \\
\text { Notice }\end{array}$ & $\mathrm{N} / \mathrm{A}$ & None & N/A & $\begin{array}{l}\text { Nordhei } \\
\text { mer }\end{array}$ & $\begin{array}{l}\text { Seeking relief } \\
\text { that cannot be } \\
\text { granted }\end{array}$ & Yes \\
\hline 177 & $\begin{array}{l}\text { Son } v \\
\text { Khan }\end{array}$ & $\begin{array}{l}06- \\
\text { Dec- } \\
16\end{array}$ & $\begin{array}{l}\text { Div } \\
\mathrm{Ct}\end{array}$ & Unclear & N/A & $\begin{array}{l}2016 \\
\text { ONSC } \\
7621, \\
{[2016]} \\
\text { OJ No } \\
6283\end{array}$ & $\begin{array}{l}\text { Granted } \\
\text { After } \\
\text { Notice }\end{array}$ & $\mathrm{N} / \mathrm{A}$ & $\begin{array}{l}\$ 2,611 . \\
93\end{array}$ & N/A & Price & $\begin{array}{l}\text { Attempt to } \\
\text { re-litigate }\end{array}$ & Yes \\
\hline 178 & $\begin{array}{l}\text { Cerqueira } \\
\text { (Estate } \\
\text { Trustee } \\
\text { of) } v \\
\text { Ontario }\end{array}$ & $\begin{array}{l}19- \\
\text { Dec- } \\
16\end{array}$ & $\begin{array}{l}\text { Div } \\
\mathrm{Ct}\end{array}$ & Unclear & N/A & $\begin{array}{l}2016 \\
\text { ONSC } \\
7961, \\
{[2016]} \\
\text { OJ No } \\
6512\end{array}$ & $\begin{array}{l}\text { Granted } \\
\text { After } \\
\text { Notice }\end{array}$ & $\mathrm{N} / \mathrm{A}$ & None & $\begin{array}{l}33 \text { Days: } \\
\text { Nov } 16, \\
2016 \text { to } \\
\text { Dec } 19 \text {, } \\
2016\end{array}$ & $\begin{array}{l}\text { Nordhei } \\
\text { mer }\end{array}$ & $\begin{array}{l}\text { Attempt to } \\
\text { re-litigate }\end{array}$ & Yes \\
\hline 179 & $\begin{array}{l}\text { Nithianan } \\
\text { than v } \\
\text { Quash }\end{array}$ & $\begin{array}{l}09- \\
\text { Jan-17 }\end{array}$ & $\begin{array}{l}\text { Div } \\
\mathrm{Ct}\end{array}$ & Registrar & N/A & $\begin{array}{l}2017 \\
\text { ONSC } \\
155, \\
\text { [2017] } \\
\text { OJ No } 62\end{array}$ & $\begin{array}{l}\text { Granted } \\
\text { After } \\
\text { Notice }\end{array}$ & $\begin{array}{l}\text { No } \\
\text { appeal } \\
\text { allowed: } \\
2017 \\
\text { ONSC } \\
1359, \\
2017 \\
\text { Carswell } \\
\text { Ont } \\
2764\end{array}$ & None & $\begin{array}{l}20 \text { Days: } \\
\text { Dec 20, } \\
2016 \text { to } \\
\text { Jan } 9 \text {, } \\
2017\end{array}$ & $\begin{array}{l}\text { Nordhei } \\
\text { mer }\end{array}$ & $\begin{array}{l}\text { Seeking leave } \\
\text { to appeal a } \\
\text { decision } \\
\text { declining } \\
\text { leave to } \\
\text { appeal. No } \\
\text { right of } \\
\text { appeal per } \\
\text { Marrocco } \\
\text { ACJ }\end{array}$ & Yes \\
\hline 180 & $\begin{array}{l}\text { Volnyans } \\
\text { ky } v \\
\text { Ontario } \\
\text { (Attorney } \\
\text { General) }\end{array}$ & $\begin{array}{l}14- \\
\text { Mar- } \\
17\end{array}$ & $\begin{array}{l}\text { Div } \\
\mathrm{Ct}\end{array}$ & $\begin{array}{l}\text { Respond } \\
\text { ing Party }\end{array}$ & $\begin{array}{l}2017 \\
\text { ONSC } \\
1692, \\
{[2017] \text { OJ }} \\
\text { No } 1330\end{array}$ & N/A & $\begin{array}{l}\text { Notice } \\
\text { Not } \\
\text { Ordered }\end{array}$ & $\mathrm{N} / \mathrm{A}$ & Unclear & N/A & Daley & $\begin{array}{l}\text { Arguable } \\
\text { attempt to re- } \\
\text { litigate }\end{array}$ & Yes \\
\hline
\end{tabular}




\begin{tabular}{|c|c|c|c|c|c|c|c|c|c|c|c|c|c|}
\hline 181 & $\begin{array}{l}\text { Apollo } \\
\text { Real } \\
\text { Estate Ltd } \\
v \\
\text { Streamba } \\
n k \\
\text { Funding }\end{array}$ & $\begin{array}{l}23- \\
\text { Mar- } \\
17\end{array}$ & $\begin{array}{l}\text { Div } \\
\mathrm{Ct}\end{array}$ & Judge & N/A & $\begin{array}{l}2017 \\
\text { ONSC } \\
1877, \\
{[2017]} \\
\text { OJ No } \\
1463\end{array}$ & $\begin{array}{l}\text { Granted } \\
\text { After } \\
\text { Notice }\end{array}$ & N/A & None & N/A & $\begin{array}{l}\text { Nordhei } \\
\text { mer }\end{array}$ & $\begin{array}{l}\text { Denying } \\
\text { frivolous } \\
\text { motion for } \\
\text { leave to } \\
\text { appeal }\end{array}$ & $\begin{array}{l}\text { Uncl } \\
\text { ear }\end{array}$ \\
\hline 182 & $\begin{array}{l}\text { Lin v } \\
\text { Fluery }\end{array}$ & $\begin{array}{l}\text { 09- } \\
\text { Jun-17 }\end{array}$ & $\begin{array}{l}\text { Div } \\
\mathrm{Ct}\end{array}$ & Judge & N/A & $\begin{array}{l}2017 \\
\text { ONSC } \\
3601, \\
2017 \\
\text { Carswell } \\
\text { Ont } 8926\end{array}$ & $\begin{array}{l}\text { Granted } \\
\text { Without } \\
\text { Notice }\end{array}$ & $\begin{array}{l}\text { Affirme } \\
\text { d: } 2017 \\
\text { ONCA } \\
695, \\
2017 \\
\text { Carswell } \\
\text { Ont } \\
13756\end{array}$ & None & $\begin{array}{l}\text { 3 Days: } \\
\text { Notice of } \\
\text { Appeal } \\
\text { filed } \\
\text { June 6; } \\
\text { appeal } \\
\text { dismisse } \\
\text { d June } 9\end{array}$ & $\begin{array}{l}\text { Nordhei } \\
\text { mer }\end{array}$ & $\begin{array}{l}\text { Dismissal of } \\
\text { appeal } \\
\text { without } \\
\text { jurisdiction }\end{array}$ & Yes \\
\hline 183 & $\begin{array}{l}\text { Khan v } \\
1806700 \\
\text { Ontario } \\
\text { Inc }\end{array}$ & $\begin{array}{l}15- \\
\text { Jun-17 }\end{array}$ & $\begin{array}{l}\text { Div } \\
\mathrm{Ct}\end{array}$ & Judge & N/A & $\begin{array}{l}2017 \\
\text { ONSC } \\
3726, \\
2017 \\
\text { Carswell } \\
\text { Ont } 9122\end{array}$ & $\begin{array}{l}\text { Granted } \\
\text { Without } \\
\text { Notice }\end{array}$ & N/A & None & $\begin{array}{l}7 \text { Days: } \\
\text { June } 8 \text {, } \\
2017 \text { to } \\
\text { June } 15 \text {, } \\
2017\end{array}$ & $\begin{array}{l}\text { Nordhei } \\
\text { mer }\end{array}$ & $\begin{array}{l}\text { Dismissal of } \\
\text { attempt to } \\
\text { appeal denial } \\
\text { of leave to } \\
\text { appeal }\end{array}$ & Yes \\
\hline 184 & $\begin{array}{l}\text { Okel v } \\
\text { Misheal }\end{array}$ & $\begin{array}{l}15- \\
\text { Oct-14 }\end{array}$ & $\mathrm{CA}$ & Judge & N/A & $\begin{array}{l}2014 \\
\text { ONCA } \\
699, \\
{[2014]} \\
\text { OJ No } \\
4842\end{array}$ & $\begin{array}{l}\text { Granted } \\
\text { After } \\
\text { Notice }\end{array}$ & N/A & None & 0 Days & $\begin{array}{l}\text { Juriansz, } \\
\text { Rouleau } \\
\text {, Pepall }\end{array}$ & $\begin{array}{l}\text { Vexatious } \\
\text { step by } \\
\text { family law } \\
\text { litigant }\end{array}$ & Yes \\
\hline 185 & $\begin{array}{l}\text { Gallos v } \\
\text { Toronto } \\
\text { (City) }\end{array}$ & $\begin{array}{l}20- \\
\text { Nov- } \\
14\end{array}$ & $\mathrm{CA}$ & Judge & N/A & $\begin{array}{l}2014 \\
\text { ONCA } \\
818, \\
{[2014]} \\
\text { OJ No } \\
5570\end{array}$ & $\begin{array}{l}\text { Granted } \\
\text { After } \\
\text { Notice }\end{array}$ & N/A & Unclear & 0 Days & $\begin{array}{l}\text { Feldman } \\
\text { Juriansz, } \\
\text { MacFarl } \\
\text { and }\end{array}$ & $\begin{array}{l}\text { Attempt to } \\
\text { re-open } \\
\text { appeal after } \\
\text { SCC denied } \\
\text { leave }\end{array}$ & Yes \\
\hline 186 & $\begin{array}{l}\text { Hoang } v \\
\text { Mann } \\
\text { Engineeri } \\
\text { ng Ltd }\end{array}$ & $\begin{array}{l}02- \\
\text { Dec- } \\
15\end{array}$ & $\mathrm{CA}$ & $\begin{array}{l}\text { Respond } \\
\text { ing Party }\end{array}$ & N/A & $\begin{array}{l}2015 \\
\text { ONCA } \\
838, \\
{[2015]} \\
\text { OJ No } \\
6316\end{array}$ & $\begin{array}{l}\text { Granted } \\
\text { After } \\
\text { Notice }\end{array}$ & N/A & $\$ 1,500$ & N/A & $\begin{array}{l}\text { Strathy, } \\
\text { LaForm } \\
\text { e, } \\
\text { Huscroft }\end{array}$ & $\begin{array}{l}\text { Second } \\
\text { attempt to } \\
\text { rehear } \\
\text { appeal; } \\
\text { causes } \\
\text { endless } \\
\text { trouble in } \\
\text { SCC }\end{array}$ & No \\
\hline 187 & $\begin{array}{l}\text { Simpson v } \\
\text { Chartered } \\
\text { Accounta } \\
\text { nts } \\
\text { Institute } \\
\text { of } \\
\text { Ontario }\end{array}$ & $\begin{array}{l}01- \\
\text { Nov- } \\
16\end{array}$ & $\mathrm{CA}$ & $\begin{array}{l}\text { Respond } \\
\text { ing Party }\end{array}$ & N/A & $\begin{array}{l}2016 \\
\text { ONCA } \\
806, \\
{[2016]} \\
\text { OJ No } \\
6382\end{array}$ & $\begin{array}{l}\text { Granted } \\
\text { After } \\
\text { Notice }\end{array}$ & N/A & None & Unclear & $\begin{array}{l}\text { Laskin, } \\
\text { Sharpe, } \\
\text { Miller }\end{array}$ & $\begin{array}{l}\text { Attempt to } \\
\text { re-litigate }\end{array}$ & Yes \\
\hline 188 & $\begin{array}{l}\text { Collins } v \\
\text { Ontario }\end{array}$ & $\begin{array}{l}\text { 19- } \\
\text { Apr- } \\
17\end{array}$ & $\mathrm{CA}$ & $\begin{array}{l}\text { Respond } \\
\text { ing Party }\end{array}$ & N/A & $\begin{array}{l}2017 \\
\text { ONCA } \\
317, \\
\text { [2017] } \\
\text { OJ No } \\
1982\end{array}$ & $\begin{array}{l}\text { Partially } \\
\text { Granted }\end{array}$ & N/A & Unclear & $\begin{array}{l}106 \\
\text { Days: } \\
\text { Jan 3, } \\
2017 \text { to } \\
\text { April 19, } \\
2017\end{array}$ & $\begin{array}{l}\text { LaForm } \\
\text { e, } \\
\text { Peppall, } \\
\text { Pardu }\end{array}$ & $\begin{array}{l}\text { Appellant } \\
\text { refusing to } \\
\text { perfect } \\
\text { appeal }\end{array}$ & Yes \\
\hline
\end{tabular}




\begin{tabular}{|c|c|c|c|c|c|c|c|c|c|c|c|c|c|}
\hline 189 & $\begin{array}{l}\text { Damallie } \\
\text { v Ping }\end{array}$ & $\begin{array}{l}17- \\
\text { Feb- } \\
17\end{array}$ & $\mathrm{CA}$ & $\begin{array}{l}\text { Respond } \\
\text { ing Party }\end{array}$ & $\begin{array}{l}2016 \\
\text { ONCA } \\
603, \\
{[2016] \text { OJ }} \\
\text { No } 4009\end{array}$ & $\begin{array}{l}2017 \\
\text { ONCA } \\
146, \\
{[2017]} \\
\text { OJ No } \\
1229\end{array}$ & $\begin{array}{l}\text { Granted } \\
\text { After } \\
\text { Notice }\end{array}$ & N/A & Unclear & $\begin{array}{l}205 \\
\text { Days: } \\
\text { July 27, } \\
2016 \text { to } \\
\text { Feb 17, } \\
2017\end{array}$ & $\begin{array}{l}\text { Gillese } \\
\text { referred } \\
\text { to } \\
\text { MacFarl } \\
\text { ane, van } \\
\text { Rensbur } \\
\text { g, } \\
\text { Huscroft }\end{array}$ & $\begin{array}{l}\text { Attempts to } \\
\text { re-litigate }\end{array}$ & Yes \\
\hline 190 & $\begin{array}{l}\text { Children' } \\
\text { s Aid } \\
\text { Society of } \\
\text { Toronto v } \\
\text { VD }\end{array}$ & $\begin{array}{l}\text { 19- } \\
\text { Jun-17 }\end{array}$ & $\mathrm{CA}$ & Judge & N/A & $\begin{array}{l}2017 \\
\text { ONCA } \\
514, \\
2017 \\
\text { Carswell } \\
\text { Ont } 9499\end{array}$ & $\begin{array}{l}\text { Granted } \\
\text { After } \\
\text { Notice }\end{array}$ & N/A & None & $\begin{array}{l}\text { 47 Days: } \\
\text { May 3, } \\
2017 \text { to } \\
\text { June } 19 \text {, } \\
2017\end{array}$ & $\begin{array}{l}\text { Epstein, } \\
\text { sent to } \\
\text { Rouleau } \\
\text { Benotto, } \\
\text { Houriga } \\
\mathrm{n}\end{array}$ & $\begin{array}{l}\text { Attempt to } \\
\text { bring } \\
\text { frivolous } \\
\text { motions and } \\
\text { appeals not in } \\
\text { interests of } \\
\text { child }\end{array}$ & Yes \\
\hline & & & & & & & & & & & & & \\
\hline
\end{tabular}

\section{APPENDIX C - COSTS ORDERS}

TABLE 2: COSTS ORDERS IN RULE 2.1 CASES

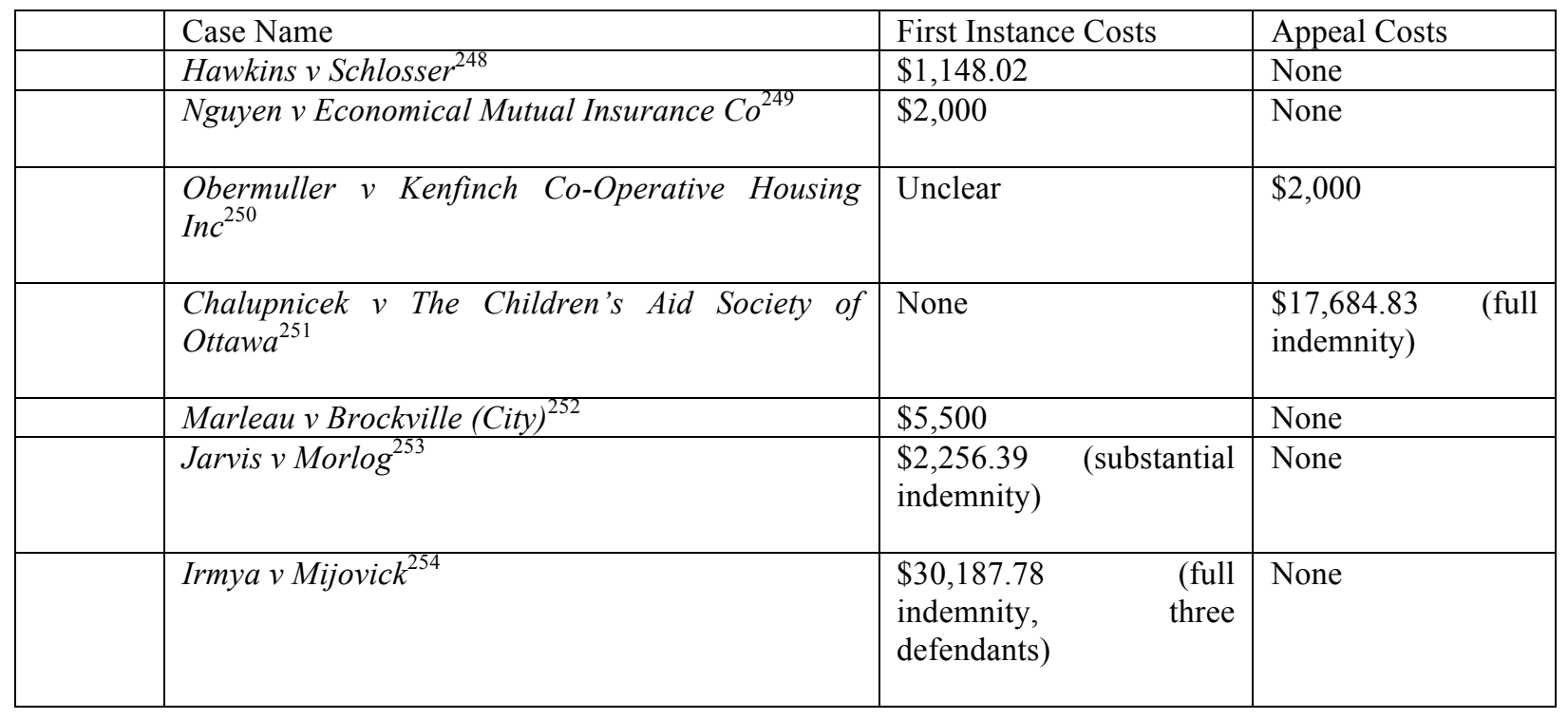

\footnotetext{
2482015 ONSC 1691, [2015] OJ No 1346 (SCJ).

249 Nguyen v Economical, supra note 49.

2502015 ONSC 6800, [2015] OJ No 5743 (SCJ), aff'd 2016 ONCA 330, [2016] OJ No 2362.

251 Chalupnicek, supra note 148.

2522016 ONSC 5901, [2016] OJ No 4961 (SCJ).

2532015 ONSC 5061, 2016 CarswellOnt 1269 (SCJ).

2542016 ONSC 5276, [2016] OJ No 4372 (SCJ).
} 


\begin{tabular}{|l|l|l|l|}
\hline & Case Name & First Instance Costs & Appeal Costs \\
\hline & Khan v Krylov \& Company LLP 255 & $\$ 3,000$ \\
\hline & Son $v$ Khan ${ }^{256}$ & $\$ 2,000$ & None \\
\hline $\begin{array}{l}\text { Gates v Humane Society of Canada for the } \\
\text { Protection of Animals and the Environment (cob } \\
\text { The Humane Society of Canada })^{257}\end{array}$ & $\$ 8,000$ & None \\
\hline Hoang v Mann Engineering Ltd & & \\
\hline
\end{tabular}

\section{APPENDIX D - CALCULATION OF DELAY}

\begin{tabular}{|c|c|c|c|c|}
\hline Disposition & $\begin{array}{l}\text { Number of } \\
\text { Cases }\end{array}$ & $\begin{array}{l}\text { Superior } \\
\text { Court }\end{array}$ & $\begin{array}{l}\text { Divisional } \\
\text { Court }\end{array}$ & $\begin{array}{l}\text { Court of } \\
\text { Appeal }\end{array}$ \\
\hline Granted & 136 & 111 & 19 & 6 \\
\hline After Notice & 121 & 99 & 16 & 6 \\
\hline $\begin{array}{l}\text { Average Delay }- \text { Excluding } \\
\text { Appeal (102) }\end{array}$ & 45 Days (102) & 45 Days (92) & 31 Days (8) & 126 Days (2) \\
\hline $\begin{array}{l}\text { Average Delay - Including First } \\
\text { Appeal (13) }\end{array}$ & 232 Days (13) & $\begin{array}{ll}274 & \text { Days } \\
(10) & \\
\end{array}$ & 80 Days (3) & N/A (0) \\
\hline $\begin{array}{l}\text { Average Delay }- \text { Including } \\
\text { Second Appeal and/or Supreme } \\
\text { Court Leave Application (13) }\end{array}$ & $\begin{array}{l}338 \text { Days } \\
\text { (4) }\end{array}$ & 411 Days (3) & 120 Days (1) & N/A (0) \\
\hline Unclear About Notice & 2 & 2 & 0 & 0 \\
\hline \multicolumn{5}{|l|}{ Delay Not Calculable } \\
\hline Without Notice & 13 & 10 & 3 & 0 \\
\hline Average Delay & \multicolumn{4}{|l|}{0 Days } \\
\hline Partially Granted & 2 & 1 & 0 & 1 \\
\hline Average Delay (2) & 84.5 Days & 63 Days & N/A & 106 Days \\
\hline $\begin{array}{l}\text { Notice Ordered of Dismissal Being } \\
\text { Considered But Final Disposition Not } \\
\text { Reported }\end{array}$ & 13 & 13 & 0 & 0 \\
\hline \multicolumn{5}{|l|}{\begin{tabular}{l|l} 
& Delay Not Calculable
\end{tabular}} \\
\hline New Pleading Ordered & 1 & 1 & 0 & 0 \\
\hline Delay (1) & \multicolumn{2}{|l|}{25 Days } & \multicolumn{2}{|l|}{$\mathrm{N} / \mathrm{A}$} \\
\hline $\begin{array}{l}\text { Resolved After Claim Withdrawn Against } \\
\text { One Defendant on Consent }\end{array}$ & 1 & 1 & 0 & 0 \\
\hline Delay (1) & \multicolumn{2}{|l|}{28 Days } & \multicolumn{2}{|l|}{ N/A } \\
\hline Dismissed & 37 & 35 & 2 & 0 \\
\hline No Notice Ordered & 27 & 26 & 1 & 0 \\
\hline Average Delay & \multicolumn{4}{|l|}{0 Days } \\
\hline After Notice & 4 & 3 & 1 & 0 \\
\hline
\end{tabular}

255 Khan, supra note 65.

2562016 ONSC 7621, [2016] OJ No 6283 (Div Ct).

2572016 ONSC 6051, [2016] OJ No 4957 (Div Ct).

258 Hoang, supra note 148. 


\begin{tabular}{|l|l|l|l|l|l|}
\hline \multicolumn{2}{|l|}{ Disposition } & $\begin{array}{l}\text { Number of } \\
\text { Cases }\end{array}$ & $\begin{array}{l}\text { Superior } \\
\text { Court }\end{array}$ & $\begin{array}{l}\text { Divisional } \\
\text { Court }\end{array}$ & $\begin{array}{l}\text { Court of } \\
\text { Appeal }\end{array}$ \\
\hline & Average Delay (3) & 108 Days & 108 Days & Unreported & N/A \\
\hline & In Context of Broader Motion & 3 & 3 & 0 & 0 \\
\cline { 2 - 7 } & Average Delay & Not Informative & 1 & 0 & 0 \\
\hline & After Amended Pleading Served & 1 & \multicolumn{2}{l}{} \\
\hline & Average Delay & 180 Days & N/A & 0 \\
\hline & After Appeal & 2 & 2 & 0 & \multicolumn{2}{l|}{} \\
\hline & Average Delay & 326 Days (1) & 326 Days (1) & N/A & 7 \\
\hline Total & 190 & 162 & 21 & \\
\hline
\end{tabular}

\section{APPENDIX E - POTENTIAL STANDARD FORM}

The defendant/respondent/responding party (circle one) asks the Court to consider using Rule 2.1 of the Rules of Civil Procedure to dismiss (name of proceeding and document filed).

The proceeding is frivolous, vexatious, and, or abusive:

_ in its entirety;

_ in part at paragraphs

The proceeding is abusive because the matters raised therein have been finally determined in a previous decision, a copy of which is attached.

- The proceeding is abusive because the matters raised therein are subject to a final release, a copy of which is attached. 